\title{
VIDA ÚTIL DOS MEXILHÕES Perna perna CULTIVADOS NO LITORAL NORTE DE SÃO PAULO: AFERIÇÃO DOS PARÂMETROS FÍSICO-QUÍMICOS E MICROBIOLÓGICOS
}

\author{
ÉRIKA FABIANE FURLAN
}

Dissertação apresentada à Escola Superior de Agricultura "Luiz de Queiroz", Universidade de São Paulo, para obtenção do título de Mestre em Ciências, Área de Concentração: Ciência e Tecnologia de Alimentos.

P I R A C I C A B A

Estado de São Paulo - Brasil

Julho - 2004 


\title{
VIDA ÚTIL DOS MEXILHÕES Perna perna CULTIVADOS NO LITORAL NORTE DE SÃO PAULO: AFERIÇÃO DOS PARÂMETROS FÍSICO-QUÍMICOS E MICROBIOLÓGICOS
}

\author{
ÉRIKA FABIANE FURLAN \\ Zootecnista \\ Orientadora: Prof ${ }^{\mathrm{a}}$. Dr ${ }^{\mathrm{a}}$. MARÍLIA OETTERER
}

\begin{abstract}
Dissertação apresentada à Escola Superior de Agricultura "Luiz de Queiroz", Universidade de São Paulo, para obtenção do título de Mestre em Ciências, Área de Concentração: Ciência e Tecnologia de Alimentos.
\end{abstract}

P I R A C I C A B A

Estado de São Paulo - Brasil

Julho - 2004 


\section{Dados Internacionais de Catalogação na Publicação (CIP) DIVISÃO DE BIBLIOTECA E DOCUMENTAÇÃO - ESALQ/USP}

\section{Furlan, Érika Fabiane}

Vida útil dos mexilhões Perna perna cultivados no litoral norte de São Paulo: aferição dos parâmetros físico-químicos e microbiológicos / Érika Fabiane Furlan - Piracicaba, 2004

95 p. : il.

Dissertação (mestrado) - - Escola Superior de Agricultura Luiz de Queiroz, 2004. Bibliografia.

1. Mexilhão 2. Salmonella 3. Segurança alimentar 4. Vida-de-prateleira I. Título

CDD 639.42 


\section{SUMÁRIO}

Página

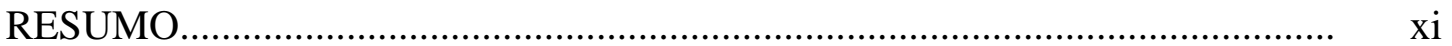

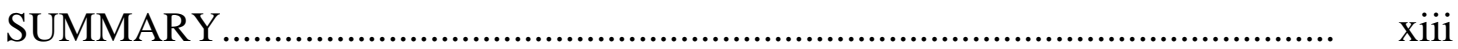

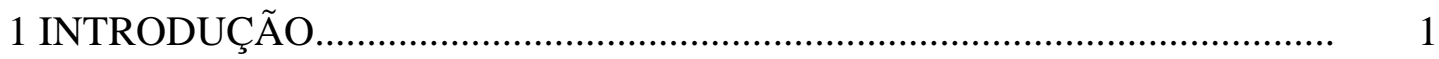

2 REVISÃO DE LITERATURA................................................................ 5

2.1 Panorama da mitilicultura no litoral Norte do Estado São Paulo................... 5

2.1.1 Desenvolvimento pesqueiro............................................................... 5

2.1.2 Produção e Produtividade.......................................................................... 7

2.1.3 Diagnóstico de mercado........................................................................ 9

2.2 A espécie Perna perna............................................................................ $\quad 10$

2.3 O mexilhão como alimento....................................................................... 11

2.4 Rendimento e tamanho dos moluscos........................................................ 14

2.5 Frescor em moluscos.......................................................................... 15

2.6 Segurança microbiológica do pescado ........................................................ 19

3 QUALIDADE FÍSICO-QUÍMICA DE MEXILHÕES Perna perna CULTIVADOS E COMERCIALIZADOS VIVOS......................................... 22

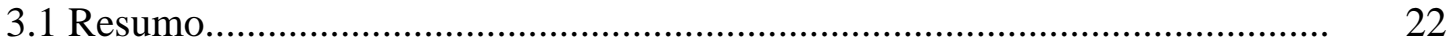

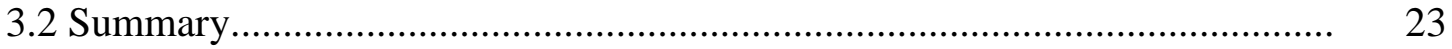

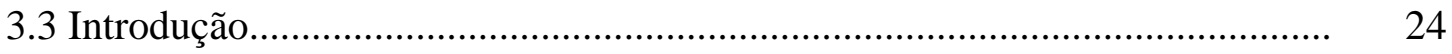

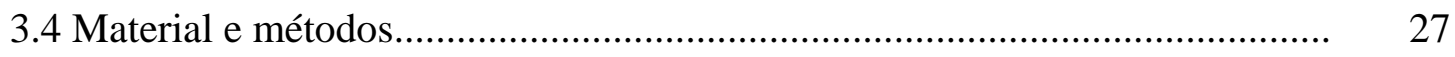

3.4.1 Pontos de coleta...................................................................................... 27 
3.4.2 Procedimento de coleta............................................................................ 28

3.4.3 Análises físico-químicas.............................................................................. $\quad 30$

3.4.3.1 Análise centesimal................................................................................... 31

3.4.3.2 Valor calórico........................................................................................

3.4.3.3 Biometria dos mexilhões......................................................................... 31

3.4.3.4 Rendimento do mexilhão..................................................................... 32

3.4.3.5 Nitrogênio Não Protéico.............................................................................. 32

3.4.3.6 Bases Nitrogenadas Voláteis Totais......................................................... 32

3.4.3.7 Determinação de $\mathrm{pH}$............................................................................... 32

3.4.3.8 Trimetilamina.........................................................................................

3.4.4 Análise estatística......................................................................................

3.5 Resultados e discussão................................................................................ 33

3.5.1 Análises físico-químicas............................................................................. 33

3.5.1.1 Composição centesimal........................................................................... 33

3.5.1.1.1 Umidade...................................................................................

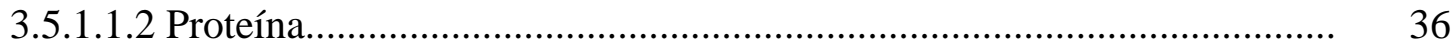

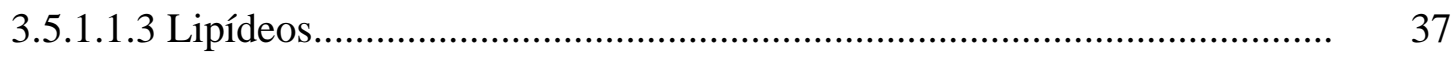

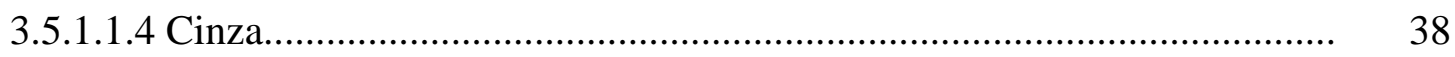

3.5.1.1.5 Carboidratos.................................................................................... 39

3.5.1.2 Valor calórico........................................................................................ 39

3.5.1.3 Rendimento $\mathrm{x}$ tamanho.......................................................................... 40

3.5.1.4 NNP........................................................... 41

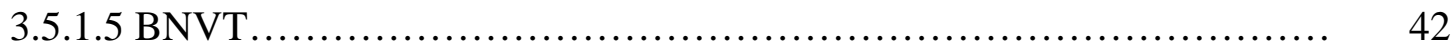

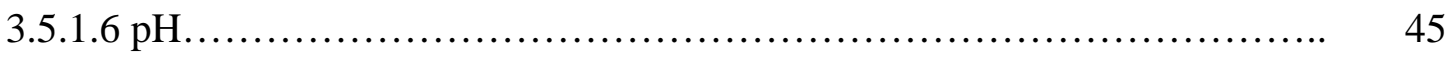

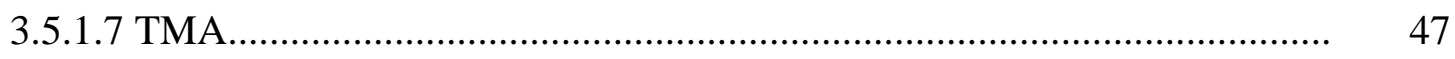

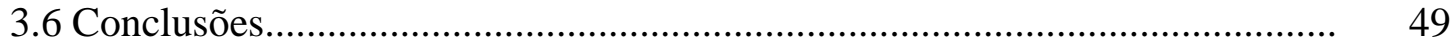

3.7 Recomendações.......................................................................................... 50

3.8 Referências bibliográficas.............................................................................. 51

4 QUALIDADE MICROBIOLÓGICA DE MEXILHÕES Perna perna CULTIVADOS EM UBATUBA, SP................................................................ 58 


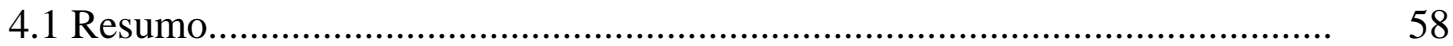

4.2 Summary ...................................................................................... 59

4.3 Introdução............................................................................................ 59

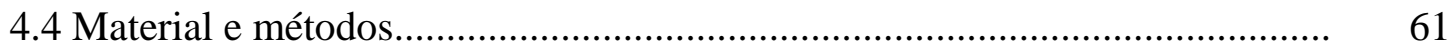

4.4.1 Escolha dos pontos de coleta..................................................................... 61

4.4.2 Caracterização dos pontos de coleta............................................................ 62

4.4.3 Matéria-prima analisada.............................................................................. 62

4.4.4 Análises Microbiológicas.............................................................................. 63

4.4.4.1 Preparo das amostras de mexilhões........................................................... 64

4.4.4.2 Microrganismos analisados nas amostras de mexilhões.............................. 64

4.4.4.2.1 Coliformes totais (CT) e coliformes fecais (CF)..................................... 64

4.4.4.2.2 Contagem de Staphylococcus aureus..................................................... 65

4.4.4.2.3 Pesquisa de Salmonella sp.................................................................... 65

4.4.4.3 Preparo das amostras de água................................................................ 66

4.4.4.4 Microrganismos analisados nas amostras de água...................................... 66

4.4.4.4.1 Coliformes totais (CT) e coliformes fecais (CF)...................................... 67

4.4.4.4.2 Staphylococcus aureus......................................................................... 67

4.4.4.4.3 Pesquisa de Salmonella sp.................................................................. 67

4.5 Resultados e discussão................................................................................... 67

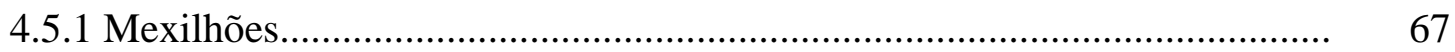

4.5.1.1 Coliformes totais e fecais...................................................................... 67

4.5.1.2 Staphylococcus aureus................................................... $\quad 71$

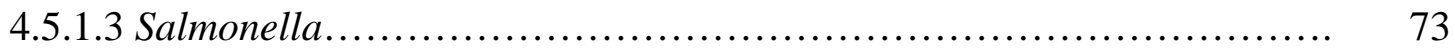

4.5.2 Água de cultivo.....................................................................................

4.5.2.1 Coliformes totais e fecais........................................................................ $\quad 74$

4.5.2.2 Staphylococcus aureus.............................................. $\quad 75$

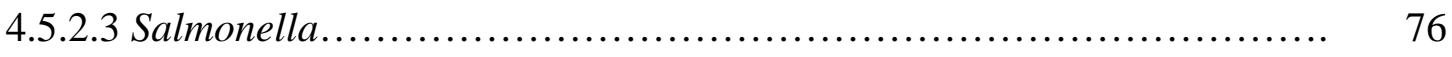

4.6 Conclusões.............................................................................................

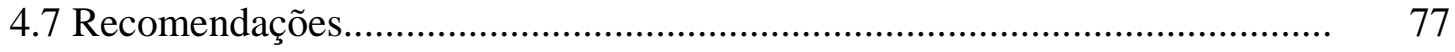

4.8 Referências bibliográficas............................................................................... $\quad 78$ 
5 CONCLUSÕES GERAIS....................................................................... 83

REFERÊNCIAS BIBLIOGRÁFICAS........................................................... 


\title{
VIDA ÚTIL DOS MEXILHÕES Perna perna CULTIVADOS NO LITORAL NORTE DE SÃO PAULO: AFERIÇÃO DOS PARÂMETROS FÍSICO- QUÍMICOS E MICROBIOLÓGICOS
}

\author{
Autora: ÉRIKA FABIANE FURLAN \\ Orientadora: Prof ${ }^{\mathrm{a}}$.Dra. MARÍLIA OETTERER
}

\section{RESUMO}

A qualidade para consumo dos moluscos bivalves está intimamente ligada a qualidade do ambiente onde estes se encontram inseridos. Em função da atual degradação ambiental, provocada pelo crescimento populacional e conseqüente aumento na descarga de dejetos no ambiente, bem como, pela ausência de programas de monitoramento da qualidade da água destinada ao cultivo destes organismos e, ainda, pelo fato da comercialização deste pescado ser realizada de forma clandestina na região de Ubatuba, SP., fez-se necessário caracterizar, sob os aspectos físico-químicos e microbiológicos, os mexilhões Perna perna cultivados e comercializados nesta região, visando a segurança do consumidor. Foram eleitas três distintas áreas de cultivo em Ubatuba, a saber; praia do Engenho da Almada, praia da Barra Seca e costão do Cedro; onde os mexilhões foram coletados, no período de novembro de 2002 a março de 2003 e submetidos às análises de nitrogênio não protéico (NNP), bases nitrogenadas voláteis totais (BNVT), trimetilamina (TMA), pH e composição centesimal. Foram também realizadas, concomitantemente, as contagens microbiológicas da carne e da respectiva 
água de cultivo quanto aos coliformes totais e fecais, Staphylococcus aureus e Salmonella sp. As amostras apresentaram qualidade satisfatória e condizente com os padrões da legislação vigente para pescado, em todos os quesitos analisados, durante a maior parte do período de estudo, excetuando-se no mês de fevereiro, quando o valor de TMA encontrado (6,9mg N/100g) superou o padrão de 4mg N/ 100g. Os mexilhões provenientes da Barra Seca, no mês de março, se apresentaram inadequados para o consumo humano direto, devido ao resultado positivo para Salmonella sp. As maiores contagens para coliformes totais ocorreram em mexilhões provenientes de áreas de cultivo densamente povoadas e que recebiam efluentes não tratados (Barra Seca), excetuando-se no mês de novembro, quando os mexilhões do costão apresentaram maior população destes microorganismos $\left(1,3 \times 10^{3} \mathrm{NMP} / \mathrm{g}\right)$. As contagens microbianas da carne do mexilhão sempre superaram a contagem da respectiva água de cultivo e, a contagem da água extrapolada pelo cultivo da Barra Seca $\left(5,7 \times 10^{1} \mathrm{NMP} / \mathrm{mL}\right)$, no mês de março, coincidiu com a detecção da Salmonella sp. neste lote. 


\title{
THE MUSSELS Perna perna SHELF-LIFE CULTIVATED IN THE SÃO PAULO STATE NORTH COAST: GAUGING OF THE PHYSICOCHEMISTRY AND MICROBIOLOGICAL PARAMETERS
}

\author{
Author: ÉRIKA FABIANE FURLAN \\ Adviser: Profa.Dra. MARÍLIA OETTERER
}

\section{SUMMARY}

The quality for consumption of the bivalve mollusks is intimately linked to the environment quality, where these are inserted. In function of the current environmental degradation caused by the growth population and consequent increase in the discharge of sewage in the environment, as well as, for the absence of quality management programs of the cultivation's waters and the Ubatuba's city, SP., clandestine marketing fish. For the consumer's safety was necessary to characterize, in the physicochemistry and microbiological aspects, the mussels Perna perna cultivated and marketed in this region. Three different cultivation points were chosen in Ubatuba; Engenho da Almada and Barra Seca's beaches and Costão's coast; where the mussels were collected for evaluation from November, 2002 to March, 2003. The analysis determined were: nonprotein-nitrogen (NPN), total volatile basic nitrogen (TVBN), trimethylamine (TMA), $\mathrm{pH}$ and proximal composition analysis's, microbiological counts of the meat and cultivation water for total and fecal coliforms, Staphylococcus aureus and Salmonella. During most of the study period, the samples presented satisfactory quality with the 
effective legislation for fish, in all the analyzed requirements, excepted on February, when the TMA value finded (6,9mg N/100g) overcome the standard 4mg N/ 100g. In March, the Barra Seca's mussels occurs inadequate for the direct human consumption, because of the positive result to Salmonella $s p$. The largest total coliforms counts happened in mussels cultivated in densely populated areas and that received sewage without previous treatment (Barra Seca), except in November, when the mussels from Cedro's coast have largest counts of these microorganisms (1,3x10 $\mathrm{NMP} / \mathrm{g})$. The microbial counts of the meat always overcame of the respective cultivation water and, the overcome of fecal coliforms count of water from Barra Seca (5,7x10 $\mathrm{NMP} / \mathrm{mL})$, on March coincided with the detection to Salmonella sp. 


\section{INTRODUÇÃO}

Durante as três últimas décadas, a aqüicultura tem crescido, diversificado e registrado avanços tecnológicos. O potencial destes avanços para garantia da segurança alimentar, crescimento econômico, comércio e melhoria na qualidade de vida é amplamente reconhecido (FAO, 2003a) e, está claramente demonstrado, pela rápida expansão do setor, que tem crescido em média $10 \%$, desde 1984, em comparação com crescimento de $3 \%$ do setor de carnes vermelhas e 1,6\% do setor da pesca extrativa (FAO, 2001).

Segundo a FAO (2003b), a pesca extrativa marinha mundial acusou decréscimo de 3,45\%, de 2001 a 2002. Este fato vem intensificar a importância da aqüicultura que, atualmente, é uma expressiva fonte de proteína animal em várias regiões do mundo. Ainda a FAO, no documento "The State of World Fisheries and Aquaculture (SOFIA)", prognosticou para os próximos 30 anos, a estagnação da produção pesqueira mundial, enquanto a produção de pescado cultivado continuará crescendo e será dominada por espécies de água doce e por moluscos. O consumo per capita de pescado está estimado para aumentar 84\% na China, 60\% no Sul da Ásia e 50\% na América Latina e Caribe (FAO, 2003c).

Segundo Westlund (2003), os fatores que contribuirão com a futura demanda de produtos pesqueiros são o crescimento populacional e econômico, a disponibilidade de renda e os fatores sociais, como os padrões tradicionais do consumo de pescado. Sendo que, ao longo dos anos, estes padrões tradicionais de consumo vêm se alterando com as mudanças sociais, como por exemplo, o estilo de vida e a estrutura familiar.

Uma simples análise do potencial de consumo de produtos pesqueiros no Brasil mostra que a demanda de, praticamente, todos os principais produtos pesqueiros está 
insatisfatória e a falta de opção de oferta destes produtos tem sido responsável pelo reduzido nível de consumo, per capita, de pescado (5,56Kg/ ano) no Brasil. É evidente que qualquer aumento no consumo de produtos pesqueiros e derivados estará relacionado com programas de mercado e especialmente, com a qualidade e apresentação final destes produtos (FAO, 2004).

A viabilidade do desenvolvimento da aqüicultura será dirigida pelo mercado, contabilizando a demanda pelo consumidor, a capacidade de adaptação da estrutura e as exigências legais do mercado alvo (Josupeit et al., 2001). É importante ressaltar que o Brasil, como depositário de um potencial natural para a produção pesqueira, tem responsabilidade dobrada ante a comunidade internacional em satisfazer suas próprias necessidades e atender a crescente demanda mundial por produtos pesqueiros (FAO, 2004).

A maricultura constitui-se no segmento de maior potencial para o incremento da produção brasileira de pescado (FAO, 2001) e está representada, basicamente, pelo cultivo de crustáceos e moluscos. O cultivo de moluscos é responsável por 24\% de toda a produção aqüícola mundial, sendo que os mexilhões representam cerca de 13,3\% da produção de moluscos cultivados (Ostrensky et al., 2000). Segundo Borghetti \& Ostrensky (2000), os moluscos produzidos no Brasil são o mexilhão Perna perna, duas espécies de ostras, a nativa Crassotrea rhizophorae e a ostra do pacífico Crassotea gigas, e a vieira Nodipecten nodosus.

Não obstante, aos vastos e variados recursos naturais, com mais de $8500 \mathrm{Km}$ longitudinais de costa marítima, a produção brasileira de moluscos está restrita ao Estado de Santa Catarina, que vem destacando-se na produção de mexilhões, tendo produzido 11500 t em 2000, caracterizando o Brasil como o principal produtor de mexilhões da América do Sul (FAO, 2004; Moluscos..., 2002).

A mitilicultura é uma das atividades mais produtivas da aqüicultura, sendo a mais próspera em diversas regiões do mundo, incluindo o Brasil, onde alcança até $30 \mathrm{t}$ de carne por ha/ano, o que representa a maior cifra obtida com modalidade de criação não sujeita a alimentação artificial. Além de diversos aspectos biológicos favoráveis, outros fatores como o baixo custo das instalações, facilidade de manejo e a localização dos 
cultivos no mar contribuíram, em muito, para a expansão mundial dessa atividade nos últimos anos (Gelli et al., 1998).

No litoral Norte de São Paulo, principalmente no município de Ubatuba, estudos de custo e benefício da mitilicultura mostraram viabilidade econômica. A atividade vem sendo praticada, comercialmente, desde 1983, porém, sem o apoio político necessário ao seu desenvolvimento. Atualmente, a produção de mexilhão do litoral Norte está em torno de 100 t/ ano (Marques \& Pereira, 1989; Proença et al., 2001; Brasil, 2002; Pereira et al., 2002).

Como relatado pela FAO (2001; 2004), a aqüicultura vem se destacando como provedora de alimentos e empregos. Tal fato pode ser confirmado pela adesão de pescadores de Ubatuba à maricultura. Em entrevista à Folha Vale, o pescador Euzébio Higino de Oliveira, 58 anos, produtor de um dos pontos de coleta da presente pesquisa, afirma estar satisfeito com a produção de mexilhões, pois, segundo o mesmo, em época de temporada, o faturamento da venda dos moluscos chega a R $\$ 2.000,00$. Enquanto, com a pesca extrativa atinge-se o salário mínimo (Ribeiro, 2002).

A expectativa de crescimento desta atividade na região, como fonte de alimento, torna evidente a necessidade e importância do controle da qualidade das águas destinadas à criação de moluscos bivalves, bem como o controle sanitário desses organismos visando garantir a qualidade deste produto no mercado (Rodrigues, 1998). Ainda mais, se considerarmos a crescente preocupação dos consumidores quanto a sanidade dos produtos alimentícios e o fato dos produtos pesqueiros, de maneira geral, serem altamente perecíveis e susceptíveis a contaminação proveniente do meio no qual estão inseridos.

A possibilidade de estabelecer programas públicos, em parceria, que possibilitem a formação de recursos humanos e que ampliem a inserção dos cidadãos no mercado de trabalho, levou o Departamento de Agroindústria, Alimentos e Nutrição da Escola Superior de Agricultura “Luiz de Queiroz” (ESALQ), da Universidade de São Paulo, a colaborar com a Prefeitura da Estância Balneária de Ubatuba, no estabelecimento de etapas de levantamento da situação da mitilicultura, diagnosticando os pontos críticos e sugerindo caminhos para tornar viável a comercialização do pescado, com valor 
agregado dirigido ao produtor, fixando-o em uma atividade sólida e rentável e de maior demanda por parte do consumidor moderno, visando como objetivo geral, a promoção na qualidade de vida dos pescadores, mediante maior grau de instrução a respeito dos alimentos, higiene e valor nutritivo e, como objetivo específico, a instalação de uma beneficiadora de pescado. O presente trabalho encontra-se inserido dentro deste programa de pesquisa em políticas públicas, financiado pela Fundação de Amparo à Pesquisa do Estado de São Paulo (FAPESP), que leva o título: "Diagnóstico e intervenções emergentes para viabilizar a comercialização e o beneficiamento do pescado e derivados -mexilhões, no litoral Norte de São Paulo” e tem como objetivo caracterizar a qualidade físico-química e microbiológica do mexilhão Perna perna cultivado e comercializado in natura pelos mitilicultores da região de Ubatuba, visando a segurança alimentar dos consumidores destes moluscos. 


\section{REVISÃO DE LITERATURA}

\subsection{Panorama da mitilicultura no litoral Norte do Estado São Paulo}

\subsubsection{Desenvolvimento pesqueiro}

A extração dos recursos marinhos tem sido, há milênios, uma atividade rotineira para as comunidades costeiras. Incerta e predatória, a utilização dos recursos pesqueiros passou, de uma atividade equilibrada e aceitável, a uma dimensão drástica de sobre exploração, provocada pelo crescente aumento populacional e, conseqüente, incremento no esforço de exploração (Gelli \& Carneiro, 2003).

Embora o Brasil apresente mais de $8.000 \mathrm{Km}$ de costa marítima, a presença de pescado em nossas águas não é intensa e sua captura é onerosa. Além disso, a estrutura de industrialização e distribuição não contribuem, de forma efetiva, para estimular o consumo do pescado brasileiro. A cadeia de intermediação do pescado talvez seja uma das mais longas presentes no setor primário. A perecibilidade deste produto e a inconstância das capturas, inerente à pesca extrativa, resultam numa considerável transferência de renda do pescador para os setores de distribuição e comercialização do produto (Cardoso, 2001).

A produção pesqueira do litoral Norte, que, segundo a Companhia de entrepostos e Armazéns Gerais do Estado de São Paulo (CEAGESP), tem caído 20\% ao ano, desde 1998, tem sido complementada, pelos restaurantes, com a compra de pescado do Sul do país e do Mercosul. A queda nos estoques pesqueiros tem sido atribuída a degradação dos manguezais, a pesca predatória e a poluição dos rios, causando também, uma redução de até $75 \%$ da renda dos pescadores locais. A renda mínima tem causado 
abandono da profissão, fato que, aliado a baixa escolaridade e limitada qualificação, dificulta o enquadramento dos pescadores em outra atividade (Ribeiro, 2002).

A crise global do setor pesqueiro tem afetado, profundamente, a qualidade de vida dos povos ligados aos ambientes aquáticos, tanto marinhos quanto continentais, especificamente dos pescadores artesanais (Arana, 2003).

Se por um lado, a pesca extrativa tem apresentado queda em seu desempenho, por outro, a aqüicultura tem apontado boas perspectivas para o setor. Sua participação na produção de pescado cresceu, de 2,5\% para 12\% entre 1990 e 1997 (FAO, 1999), revelando um campo potencial para incremento da produção. Dentro da aqüicultura, a maricultura pode significar uma alternativa econômica para os pescadores e suas comunidades, pois tem mostrado resultados positivos nas áreas em que é implantada, podendo-se afirmar que se trata de uma atividade com futuro promissor, além de ser uma forma não predatória de uso dos recursos naturais (Arana, 1999; Cardoso, 2001).

A mitilicultura vem sendo praticada, comercialmente, em Ubatuba desde 1983, porém, sem um apoio político necessário ao seu desenvolvimento. Em contrapartida, no Estado de Santa Catarina, onde houve grande empenho para o desenvolvimento da atividade, o cultivo do mexilhão Perna perna teve início em 1986 e já responde por cerca de 93\% da produção nacional de mexilhões (Proença et al., 2001; Brasil, 2002). Nestes poucos anos, a atividade em Santa Catarina envolveu cerca de 800 produtores, foram criadas 13 associações e construídas 4 unidades de processamento de moluscos. $\mathrm{O}$ número de empregos diretos gira em torno de 4.000 pessoas/ ha de cultivo de mexilhão e tem possibilitado a geração de até 52 empregos indiretos (Moluscos..., 2002).

A exemplo do Estado de Santa Catarina, vê-se grandes chances de um desenvolvimento sustentado da mitilicultura no litoral Norte do Estado de São Paulo, onde pesquisas estimam que exista uma área disponível em torno de 8.000 ha, propícia ao desenvolvimento da atividade, havendo 30 pontos demarcados no município de Ubatuba.

Yokoyama et al. (2003), verificaram que o desenvolvimento da mitilicultura em Ubatuba está proporcionando estabilidade e segurança às famílias envolvidas na atividade. No litoral Norte de São Paulo, pesquisas foram iniciadas nos primórdios dos 
anos 70, existindo hoje, uma tecnologia definida e em uso por 18 núcleos de produção, sendo 10 destes no município de Ubatuba e na sua maioria formados por comunidades de pescadores artesanais (Marques \& Pereira, 1989; Proença et al., 2001; Brasil, 2002).

O município de Ubatuba é constituído de 78 praias e segundo dados do IBGE, obtidos no Censo do ano de 2000, possui uma população de 66.448 habitantes, sendo este número duplicado nos finais de semana prolongados e na alta temporada; é considerado um local excelente para implantação da maricultura, visto sua localização, relativamente próxima aos principais centros consumidores, São Paulo e Rio de Janeiro (Companhia de Tecnologia de Saneamento Ambiental (CETESB), 2001; Jacob, 2002).

\subsubsection{Produção e produtividade}

No litoral Norte de São Paulo existem 77 famílias cadastradas como produtoras de mexilhão Perna perna. Os criadores estão organizados em associações e as fazendas marinhas estão localizadas em 23 praias ao longo do litoral. Cada fazenda ocupa cerca de $2.000 \mathrm{~m}^{2}$ de lâmina d’água e produz em média $12 \mathrm{Kg}$ de mexilhão/ metro linear de rede (Gelli et al., 2002).

O sistema de cultivo utilizado pelos produtores do litoral Norte e denominado espinhel, ou "long line”, é adaptado às condições oceanográficas da costa paulista, de fácil manejo e exige pequeno investimento. A semeadura é realizada com base no sistema francês, permitindo que cada sistema simples implantado produza até duas toneladas de mexilhões em casca, por safra, em um período que varia de 6 a 9 meses, conforme o local de produção (Pereira et al., 2002).

As técnicas de criação de mexilhões foram aprimoradas e difundidas pelo Instituto de Pesca /Agência Paulista de Tecnologia do Agronegócio (Apta) da Secretaria da Agricultura e Pesca (SAA) e suas parcerias, Coordenadoria de Assistência Técnica Integral (CATI), de São Sebastião e o Departamento de Pesca e Aqüicultura (DPA) do

Ministério da Agricultura, Pecuária e Abastecimento (MAPA), através de cursos e assistência técnica às comunidades de pescadores locais, resultando no aumento de 9, 
para 90 produtores, no litoral Norte paulista, nos últimos cinco anos, sendo 42 mitilicultores no município de Ubatuba (Gelli \& Carneiro, 2003).

A Associação dos Maricultores do Estado de São Paulo (AMESP) conta, atualmente, com 115 associados. A implantação do sistema de geo-referenciamento para a implantação da maricultura, a padronização do cenário e o zoneamento das fazendas marinhas, ações estas coordenadas pelo Instituto de Pesca, com a participação das demais parcerias, Secretaria do Meio Ambiente, Instituto Brasileiro do Meio Ambiente (IBAMA), DPA/ MAPA, colônias de pesca, prefeituras municipais e universidades, estão propiciando o desenvolvimento ordenado das fazendas mexilhoneiras na região (Gelli \& Carneiro, 2003).

Segundo o Programa de Desenvolvimento da Criação Ordenada de Moluscos Bivalves do Estado de São Paulo, no município de Ubatuba foi reservada uma área de 60 ha onde a atividade é viável. Os resultados da mitilicultura experimental, em Ubatuba, apontaram uma produtividade de 30 t de mexilhões em casca/ ha. Se for considerada a capacidade média de suporte observada em cultivos na Galícia (Espanha), que é de 750 redes/ ha, o potencial de produção do município passa a ser de 1800 t/ ano (Marques \& Pereira, 1989). Estes mesmos autores realizaram um levantamento preliminar, em 1989, quanto as áreas mais favoráveis à mitilicultura no litoral do município de Ubatuba e concluíram que a atividade pode ser praticada no município em cerca de 4100 ha, distribuídos ao longo deste litoral. O potencial de produção desta área é, de acordo com as mesmas estimativas, cerca de 125.000 t de mexilhões em casca/ ano. Do ponto de vista econômico, esse potencial justifica plenamente a delimitação e a preservação destas áreas para fins da prática da mitilicultura. Assim, somente a produção de Ubatuba poderá ser suficiente para colocar o Brasil como $2^{\circ}$ produtor mundial de mexilhões, abaixo apenas da Espanha, que produz cerca de 360 mil toneladas anuais (Marques \& Pereira, 1989).

Atualmente, a produção de mexilhão do litoral Norte está em torno de 100 t/ ano e, como todas as iniciativas de criação de moluscos bivalves no país, ainda pode ser considerada clandestina, no que se refere a legalização de uso da área. Isso ocorre, porque somente em 24 de novembro de 2003, durante a Conferência Nacional de 
Aqüicultura e Pesca, realizada em Luziânia, no Estado de Goiás, foi sancionado o Decreto $n^{0} 4895$ que “dispõe sobre a autorização de uso de espaços físicos de corpos d’água de domínio da União para fins de aqüicultura” e, com a publicação deste Decreto, foi revogado o Decreto $\mathrm{n}^{\circ} 2869$ que permanecia com suas normas complementares ainda não aprovadas, o que dificultava a aquisição do Registro do aqüicultor por parte dos criadores e, conseqüentemente, de financiamentos e garantias previstos no corpo do Decreto (Pereira et al., 2002; Panorama da Aqüicultura, 2003).

\subsubsection{Diagnóstico de mercado}

A falta de um sistema de inspeção para moluscos cultivados é um fator de restrição ao consumo. Não existe atuação do Serviço de Inspeção Estadual (SISP) para moluscos em São Paulo. O Estado conta apenas com duas unidades para depuração de ostras, operando com o Serviço de Inspeção Federal (SIF). A implantação de unidades de beneficiamento, com SIF, permite a ampliação do mercado, inclusive a comercialização em outros Estados da Federação. A existência de produtos inspecionados e não inspecionados causa uma concorrência desleal no mercado, dado que as unidades inspecionadas arcam com os custos necessários para se obter a certificação (Serviço de Apoio às Micro e Pequenas Empresas de São Paulo (SEBRAE), 2002).

A comercialização de mexilhões é praticada localmente (Ubatuba, SP) durante todo o ano, concentrando-se no verão, em função da presença dos turistas. Estes são os maiores consumidores, juntamente com os restaurantes e bares locais. O comportamento do consumidor é influenciado por variáveis sócio-demográfico-culturais, variáveis psicológicas (estilo de vida, motivação) e por situação de compra. Com relação a frequência do consumo, 39,31\% dos paulistanos afirmam consumir moluscos poucas vezes ao ano e 26,21\%, apenas nos meses do verão. Apesar do consumidor preferir, em $52,08 \%$ das vezes, consumir o produto em casa, observa-se um valor relevante para o consumo em restaurantes, da ordem de 34,38\% (Barni et al., 2003). 
Nesta mesma pesquisa, efetuada pela Empresa de Pesquisa Agropecuária e Extensão Rural de Santa Catarina (EPAGRI), em três estados brasileiros, entre eles o Estado de São Paulo, atesta-se uma clara preferência pelo produto a granel, desconchado e fresco (resfriado). No entanto, devido a sua natureza perecível e a limitada capacidade de armazenamento, faz-se necessário o desenvolvimento de embalagens, a redução dos custos de distribuição e o transporte rápido, econômico e adequado (Barni et al., 2003). Ainda nesta pesquisa, realizada em 2002, foram sinalizados os principais canais de distribuição dos moluscos na cidade de São Paulo, sendo, 52,82\% nos supermercados, 21,13\% nas peixarias de bairro, $19,01 \%$ no mercado municipal e 3,52\% direto do produtor.

Atualmente, o mercado distribuidor de moluscos no Estado de São Paulo tem como característica principal a clandestinidade. Nesse mercado, a maioria dos atravessadores comercializa o produto proveniente do extrativismo, não certificado sanitariamente, comprando dos produtores a um preço irrisório e vendendo ao consumidor final com um lucro excessivo, sem qualquer garantia.

Em Ubatuba, a forma predominante de comercialização é in natura e na concha (mariscado) e o preço é ditado pelo mercado consumidor (Rinaldi, et al., 2003). Os bivalves podem sobreviver fora d’água por extensos períodos, o que permite a comercialização deste alimento vivo. No entanto, alguns mitilicultores não comercializam toda a produção anual desta forma, parte da produção é comercializada desmariscada (refrigerada e sem a concha). No momento, tal fato talvez seja o principal problema da comercialização, pois não há na região nenhuma indústria ou similar que beneficie o produto. Desta forma, o próprio produtor precisa desmariscar o mexilhão e, muitas vezes, em condições precárias.

\subsection{A espécie Perna perna}

O mexilhão Perna perna, vulgarmente conhecido como marisco, é um molusco bivalve de grande importância econômica, visto tratar-se de um organismo marinho amplamente utilizado na alimentação humana. 
Considerado o maior mitilídeo brasileiro, apresenta a seguinte classificação taxonômica: Filo Mollusca; Classe Bivalvia; Ordem Mytiloida; Família Mytilidae; Gênero Perna e Espécie Perna perna (Rosa et al., 1994; Marques, 1998).

O gênero tropical Perna encontra-se distribuído pelos oceanos Atlântico (costa da América do Sul e África) e Índico (África, Ásia e Oceania), além do mar mediterrâneo na costa africana (Marques, 1998). Esta espécie foi, provavelmente, introduzida no Brasil nos séculos XVI a XIX com as águas de lastro e/ou incrustações dos navios negreiros, vindos da África. Hoje, é abundante entre o litoral do Espírito Santo e Rio Grande do Sul (Marques, 1998; Souza, 2003). São bivalves filtradores e se revelam adequados à utilização como bioindicadores devido a natureza séssil, que facilita sua coleta e ao seu elevado fator de concentração, bem como, a ampla distribuição (Lamparelli, 1987).

Em bivalves, as brânquias, responsáveis tanto pela respiração quanto pela filtração e retenção de alimento, não apresentam capacidade seletiva de filtração, sendo a ingestão de partículas limitada apenas pelo tamanho destas.

A espécie Perna perna, anteriormente denominada Mytilus perna, é estritamente dióica, tendo a reprodução sexuada como padrão reprodutivo. O dimorfismo sexual nos Bivalvia é muito raro, normalmente reconhecido pelo exame microscópico das gônadas. No caso do Perna perna, machos e fêmeas podem ser diferenciados, internamente, em algumas fases do ciclo reprodutivo, quando a coloração das gônadas nos machos apresentam-se branco-leitosa e nas fêmeas vermelho-alaranjado (Lunetta, 1969).

\subsection{0 mexilhão como alimento}

O cultivo de moluscos foi realizado, inicialmente, pelos japoneses (2000 a.C.) e romanos (100 a.C.). Alcançando, nos dias atuais, elevado nível tecnológico e dispondo ao consumidor um alimento nutritivo e de grande demanda (José, 1996).

Os mexilhões Perna perna apresentam teores protéicos médios de 9,9\% em relação ao peso fresco, sendo que os animais sexualmente maduros apresentam teores protéicos ainda maiores (Magalhães, 1985). Segundo Marques (1998), esse valor é 
superior ao da ostra (5,7\%) e ao de muitos peixes marinhos. Medeiros et al (2001) analisando ácidos graxos de mexilhões P.perna detectaram grande proporção de EPA ácido eicosapentaenóico (11,27\%) e DHA - ácido docosahexaenóico (12,53\%), na fração lipídica. Estes autores também verificaram a presença do ácido palmítico (22\%). Podendo-se, portanto, recomendar a ingestão deste alimento como fonte de $\omega$-3, importante à prevenção de doenças cardiovasculares.

O mexilhão, no entanto, é considerado uma iguaria, não fazendo parte do cardápio diário da população e, sua aceitação, restringe-se a uma camada muito pequena de consumidores. Trata-se de um produto, cuja perecibilidade exige muito cuidado no manuseio e conservação. Porém, tanto o produtor como os demais segmentos do mercado ainda não possuem organização e infraestrutura adequada para colocar o produto com total segurança e aceitabilidade no mercado consumidor, garantindo a demanda (Rosa, et al., 1994).

Grande parte da comercialização de moluscos bivalves é realizada na forma viva. Portanto, estes podem se contaminar e recontaminar ativamente em todas as etapas, inclusive durante o transporte e estocagem, se realizados de forma inadequada (José, 1996). Veículos de coleta e transporte devem se apresentar limpos e construídos de maneira a não contaminarem os moluscos durante o carregamento. Não forma estabelecidos requerimentos quanto aos métodos de transporte de moluscos sob refrigeração ou com gelo. Na prática, bactérias podem se multiplicar, substancialmente, se moluscos forem alojados nas embarcações em temperaturas elevadas. Esta é uma das etapas onde o sistema poderia ser melhorado, contudo, a maioria das embarcações para captura são rudimentares e a refrigeração torna-se impraticável. Os bivalves embarcados devem ser mantidos úmidos sob temperatura de refrigeração, mas nunca em contato com a água doce fundida, pois esta situação os levaria à morte; esta então, deve ser drenada livremente (Doré, 1941).

É no estado fresco que o mexilhão é exportado entre os países da Europa. Assim, a França importa mexilhões produzidos na Espanha e na Holanda. Entretanto, após a intensificação da mitilicultura na Espanha surgiu mercado para várias formas de conservas enlatadas, uma vez que devido as grandes distâncias, entre as fontes de 
produção e o mercado consumidor, o produto comercializado fresco é muito oneroso quanto ao transporte, tendo em vista que $2 / 3$ do peso do mexilhão é constituído pelas conchas. Na Espanha, 50\% da produção, no ano de 1980, era comercializada no estado de fresco (Espínola e Dias, 1980).

Historicamente, as medidas adotadas, visando o controle sanitário, diferem entre os diversos países, não existindo consenso quanto aos procedimentos mais adequados para minimizar o risco à saúde pública representado pelo consumo destes organismos (José, 1996). Na prática, todas as etapas, da produção à comercialização, são passíveis de controle sanitário.

Em Ubatuba, onde a produção de mexilhões ainda ocorre de forma artesanal, após coleta, esses são classificados (por tamanho e separados das conchas quebradas e com defeitos), lavados e embalados em sacos de ráfia ou apenas empilhados sobre mesas ou outros tipo de apoio, geralmente de madeira, sendo que, algumas vezes, esta manipulação ocorre sob radiação solar direta, sem nenhum tipo de sombreamento. O produto tem boa aceitabilidade ao longo do litoral.

Segundo o Regulamento de Inspeção Industrial e Sanitária dos Produtos de Origem Animal (RIISPOA), do Ministério da Agricultura, Pecuária e Abastecimento, os moluscos bivalves devem ser expostos à venda vivos, com as valvas fechadas e retenção de água incolor e límpida nas conchas (Brasil, 1980). Para o programa canadense, estes devem apresentar-se refrigerados quando comercializados in natura e devem ser mantidos em recipientes com livre circulação do ar. Quando desmariscados (retirados da concha) deve-se mantê-los refrigerados e o consumo deve ocorrer dentro de 2 a 3 dias (Canadá, 2004).

Segundo Wood (1979) e Huss (1993), a coç̧ão aplicada, artesanalmente, nos mexilhões visa apenas facilitar a abertura das valvas, pelo relaxamento do músculo adutor, mas não exerce nenhum efeito sobre a contaminação microbiana destes animais. A carne desconchada deve ser lavada, embalada e vendida fresca ou congelada, ou ainda, submetida ao enlatamento. Para a comercialização do produto desmariscado e congelado, a carne, após acondicionamento em sacos plásticos, deve ser, imediatamente, submetida ao congelamento a $-35^{\circ} \mathrm{C}$. Neste caso, o transporte para longas distâncias, 
deve ser feito em veículos isotérmicos (Marques, 1998). Na Galícia, Espanha, dispõe-se de uma rede de transporte refrigerado, composta por caminhões e vagões isotérmicos, para os bivalves destinados ao consumo fresco (Andreu, 1976).

Como todo alimento aquático, os moluscos bivalves devem ser cultivados em águas limpas e livres de esgoto, entre outros resíduos. Nos laboratórios do Centro de Biologia Marinha (CEBImar) e no Instituto de Biociências, da Universidade de São Paulo (USP), estudos de monitoramento da presença de toxinas marinhas, iniciaram-se em meados da década de oitenta, constatando a existência das mesmas no litoral de São Paulo, porém em quantidades residuais, sem oferecer perigo aos consumidores de mariscos. (Freitas, 2003).

\subsection{Rendimento e tamanho dos moluscos}

Os moluscos e crustáceos apresentam rendimento menor que os peixes. O rendimento de carne útil para a industrialização (congelados, enlatados, salgados) é fortemente afetado pelo tipo de concha ou carapaça que, por sua vez, varia de acordo com o habitat e estado fisiológico do animal. Há moluscos, nos quais, é consumido apenas o músculo adutor, como nas vieiras; ou as gônadas, como nos ouriços (ContrerasGuzmán, 1994). Os mexilhões Perna perna são consumidos inteiros, após retirada das valvas e os registros quanto ao rendimento destes ainda são escassos (Antoniolli, 1999). Beirão (2002) ${ }^{1}$ encontrou valores de rendimento de aproximadamente $11 \%$ para a proporção concha/carne.

Sabe-se que o crescimento e a produtividade dos mexilhões, de cultivo ou de bancos naturais, dependem de diversos fatores como temperatura, salinidade, circulação de água, densidade de indivíduos, quantidade e qualidade do alimento disponível e incidência de parasitas, competidores e predadores. Henriques (2001) constatou crescimento menor para os organismos com grandes quantidades de cracas.

O peso e o volume de carne dos mexilhões estão intimamente ligados a fatores

${ }^{1}$ BEIRÃO, L.H. Industrialização de mariscos e ostras. In: ENCONTRO DO AGRONEGÓCIO DA PESCA E AQUICULTURA, 1., Santos, 2002. (Comunicação Pessoal) 
relacionados a reprodução, pois, antes da mesma, o manto apresenta-se repleto de gametas. Sendo, nesta fase, encontrados os maiores valores de rendimento (Marques, 1998). Este autor também sinalizou que, no litoral paulista, os mexilhões costumam ser comercializados a partir dos $5 \mathrm{~cm}$ de comprimento, não sendo vantajoso para o produtor esperar os animais atingirem comprimentos maiores para comercializa-los, já que o crescimento, praticamente, se estabiliza aos $6 \mathrm{~cm}$. Em outros Estados, como Rio de Janeiro e Santa Catarina, a comercialização dos bivalves se dá quando estes atingem 7 a 9 cm. Segundo Assumpção (1999), os mexilhões em Ubatuba, SP, apresentam uma variação de tamanho entre 6,0 a 7,1cm, após 9 meses de cultivo, se as sementes são provenientes de bancos naturais.

Na Espanha, segundo Marques (1998), os mexilhões Mytilus edulis atingem 6,8cm, após 12 meses de cultivo; nos Estados Unidos, região do Maine, 4,3 cm e, na Inglaterra, 4,5 cm, neste mesmo período. Os fatores ambientais exercem, portanto, influência direta sobre o crescimento destes organismos.

Gomes et al. (1998), considerando o cálculo de rendimento do mexilhão P.perna, propõem o rendimento de 14,81\% como índice de condição comercial mínimo; 21,64\% como médio e 40,32\% máximo, afirmando que estas variações ocorrem, principalmente, em função de interferências sazonais do ambiente no desenvolvimento do bivalve.

Segundo Quayle \& Newkirk (1989), o crescimento da concha é altamente dependente da temperatura; quando a temperatura da água é elevada o ano todo, o crescimento ocorre de forma contínua. Em regiões tropicais, onde as temperaturas sofrem menor variação, a interrupção do crescimento é causada pela variação da salinidade.

\subsection{Frescor em moluscos}

O grau de frescor de um alimento marinho caracteriza-o em estágios de excelência, definidos pela salubridade e aceitabilidade sensorial do produto pelo consumidor, ou seja, as características sensoriais (aparência, textura, odor e flavor) normalmente associadas a este alimento (Botta, 1994). 
A salubridade é avaliada pela composição química do alimento e pela presença de compostos de origem endógena ou ambiental sujeitos a alterações fisiológicas (Sikorski \& Sun Pan, 1994). Álcoois insaturados e aldeídos com menos de 10 carbonos, são importantes contribuintes para o frescor e flavor característico de moluscos e crustáceos in natura. Estes produtos, quando frescos, apresentam odor pouco intenso e o flavor é similar ao das frutas ou algas marinhas (Botta, 1994).

A ação de fechar as valvas quando estão em contato com o ar, a elasticidade da carne e as cores vivas são sinais de frescor (Brasil, 1980; Beirão et al., 2000). Em condições de anóxia, os fosfatos orgânicos e carboidratos presentes na carne do pescado, recém capturado, continuam sendo metabolizados devido a ação de enzimas tissulares e, subseqüentemente, são desdobrados pelas bactérias. As alterações nas concentrações de açúcares e glucofosfatos, nos músculos, contribuem para perda gradual do odor e do sabor característicos do pescado fresco (Sikorski et al., 1994).

A carne de pescado possui vida comercial muito restrita e variável. O local e as condições de cultivo, a época do ano na qual ocorre a coleta, o método de coleta e a manipulação pós captura atuam, diretamente, sobre a qualidade do pescado (Botta, 1994). Para Spinelli et al., (1964), um método objetivo ideal para mensuração da qualidade em pescado, fresco ou congelado, deveria correlacionar a qualidade com o tempo e temperatura de estocagem pós captura, fornecendo uma base para estimar sua vida útil.

Os padrões de qualidade do pescado e derivados estão baseados na análise de compostos como bases nitrogenadas voláteis totais (BNVT) e trimetilamina (TMA) e, segundo o Ministério da Agricultura, Pecuária e Abastecimento, que regulamenta o RIISPOA -Regulamento de Inspeção Industrial e Sanitária de Produtos de Origem Animal, os níveis de BNVT devem ser inferiores a 0,03 g de nitrogênio por 100 g de carne e bases voláteis terciárias inferiores a 0,004g N, em $100 \mathrm{~g}$ (para atestar frescor ao produto); para $\mathrm{pH}$ da carne, os níveis externos aceitáveis são os inferiores a 6,8 e internos a 6,5. Determinam também o frescor, a reação negativa para gás sulfídrico e de indol, com exceção de alguns crustáceos onde o limite é de, no máximo, 4g/ 100g de carne (Brasil, 1980). 
Em pescado marinho, as BNVT primariamente incluem a TMA, a amônia e a dimetilamina (DMA). Cada um destes compostos, tão bem quanto as BNVT, se constitui em um índice útil para aferir a deterioração em diferentes alimentos marinhos frescos ou em semiconservas (EU Commission, 2004).

Para a determinação das BNVT emprega-se um método relativamente simples e, conseqüentemente, largamente utilizado para avaliar quimicamente o frescor de um alimento marinho (Botta, 1994; Amanajás, 1985). Entretanto, Antanacopoulos \& Vincke (1989), conduziram estudo sobre estas bases e concluíram que a determinação das BNVT deveria ser um método de rotina, somente utilizado para determinar se o pescado é próprio para o consumo humano, pois esta análise não permite a identificação de estágios iniciais de frescor do pescado.

A determinação química do nível de TMA está entre os métodos mais investigados para a mensuração da qualidade de alimentos marinhos e parece ser promissora na detecção do grau de deterioração de uma amostra de pescado (Eiroa, 1980). Segundo Hebard et al. (1982), esta mensuração tem sido apontada como um índice útil de frescor para muitas espécies marinhas.

Para Rodríguez-Jérez et al. (2004), a determinação das BNVT não deve ser considerada um método seguro para todas as espécies de pescado, e os teores de BNVT e de TMA não são índices sensíveis de frescor devido a elevada variabilidade. Então, estes testes devem ser reservados para avaliação do pescado próximo ao seu limite de aceitabilidade.

Em adição à determinação do BNVT e TMA, a degradação de nucleotídeos post mortem, a formação de aminas biogênicas e etanol têm também sido utilizadas para mensurar flavor e odor quanto aos aspectos de qualidade (frescor). E, embora as aminas biogênicas, particularmente a histamina, sejam de grande interesse, do ponto de vista da segurança alimentar, uma das principais desvantagens de usá-las como indicadoras de frescor é que a simples ausência destas não, necessariamente, indica boa qualidade do produto (Botta, 1994).

Substâncias nitrogenadas não protéicas como, inosina, ribose, uréia, e óxidos de trimetilamina, de baixo peso molecular, são resultantes da ação enzimática no músculo 
do pescado, constituindo-se em substratos preferenciais para a utilização microbiana, que acarreta profundas alterações organolépticas no pescado (Beirão et al., 2000; Pregnolatto \& Pregnolatto, 1985).

Aferir o frescor do pescado é muito importante, na indústria, para elaboração de produtos de alta qualidade. A mensuração dos nucleotídeos produzidos pela decomposição do ATP -trifosfato de adenosina é considerado como o indicador mais confiável de frescor (Ogawa \& Maia, 1999; Rodríguez-Jérez et al., 2004). O método de separação e quantificação dos nucleotídeos apresenta a vantagem de evitar as interferências dos componentes adicionais dos mariscos e permite a soma de todos os catabólitos, facilitando a apresentação dos resultados como percentagem do total. Este índice, denominado valor K, foi proposto primeiramente por Saito et al. (1959) ${ }^{2}$ e recomendado por Hiltz et al. (1971); Ehira \& Uchiyama, (1987); Botta, (1994); Ogawa \& Maia, (1999) e Davis (1999).

A hipoxantina $(\mathrm{Hx})$ é um dos produtos da decomposição do ATP e a sua determinação também foi proposta como indicador do grau de frescor para espécies de pescado, tipicamente, acumuladoras desta substância (Hiltz et al., 1971).

Outro fator qualitativo do pescado é o referente aos lipídeos, que possuem grande quantidade de ácidos graxos insaturados e, portanto, são altamente susceptíveis à oxidação, que é acelerada pela presença de luz, calor, irradiação e metais pesados, porém retardada com a adição de antioxidantes que atuam rompendo a cadeia de radicais livres ou decompondo os peróxidos (Beirão et al., 2000).

Quando comparados a outros tipos de pescado, os moluscos apresentam em sua carne um teor relativamente elevado de carboidratos, o que, certamente, faz com que seu processo deteriorativo seja diferenciado dos demais produtos pesqueiros, trazendo à tona a necessidade de mais estudos e uma legislação específica para estes organismos. Devido a complexidade do processo de decomposição do pescado, torna-se inviável o uso de um método isolado na avaliação de sua qualidade. A determinação da qualidade do pescado deve ser criteriosa, visto que há inúmeras espécies de pescado e o curso da

\footnotetext{
${ }^{2}$ SAITO, T.; ARAI, K.;YAJIMA, T. Changes in purine nucleotides pf red lateral muscle of rainbow trout. Nature, v.185, p.1415, 1959.
} 
deterioração é diferente quando comparamos espécies, indivíduos de uma mesma espécie e até partes de um mesmo indivíduo (Ogawa \& Maia, 1999).

\subsection{Segurança microbiológica do pescado}

A rápida deterioração na qualidade do pescado fresco é causada por atividades microbianas e de enzimas endógenas no animal post mortem. A fração de nitrogênionão-protéico da carne de pescado consiste de compostos nitrogenados de baixo peso molecular solúveis em água, tais como, aminoácidos e nucleotídeos, que formam um substrato útil para crescimento microbiano.

A biota do pescado tropical, às vezes, contém uma carga levemente maior de bactérias gram-positivas e entéricas, mas segundo Liston (1980), é similar a biota do pescado de águas temperadas.

A contagem do número de células viáveis é, relativamente, complexa e consome tempo, não sendo um método prático para estimação do frescor, em contrapartida, a qualidade microbiológica dos alimentos marinhos é um fator chave para a comercialização e segurança para o consumo. Alguns países, como os Estados Unidos praticam o monitoramento microbiano das águas de cultivo.

No Brasil, não existe ainda um programa de monitoramento. De acordo com o Ministério da Agricultura, através da informação DIPES 097/88, os limites microbiológicos para as áreas de criação, extração e manutenção dos moluscos bivalves são os seguintes Área proibida: N.M.P. de Bactérias Coliformes > 700/100 mL; Área Limitada: N.M.P. de Bactérias Coliformes entre 700 e 70/ 100 mL, sendo indispensável

o tratamento dos moluscos através da depuração. Área Livre: N.M.P. de Bactérias Coliformes < 70/ $100 \mathrm{~mL}$ (Brasil, 1988).

O Conselho Nacional do Meio Ambiente (CONAMA), do Ministério do Meio Ambiente, pela resolução 20, de 18 de junho de 1986, classifica as águas marinhas para a criação, natural e/ ou intensiva, de espécies destinadas à alimentação humana, que serão ingeridas cruas, como pertencentes à Classe $\mathrm{V}$, ou seja, não devem ultrapassar a 
concentração média de 14 coliformes fecais/ $100 \mathrm{~mL}$, com não mais de $10 \%$ das amostras excedendo 43 coliformes fecais/ 100 mL. (Brasil, 1986).

O National Shellfish Sanitation Program (NSSP), órgão cooperativo de representantes de produtores de moluscos dos Estados Unidos, a indústria privada e o Food and Drug Administration (FDA) têm, tradicionalmente, utilizado como parâmetro de controle, tanto o grupo de coliformes totais, como fecais, visando assegurar a qualidade das áreas de cultivo. O Canadian Shellfish Sanitation Program (CSSP) também segue as prerrogativas estabelecidas no programa americano (Estados Unidos, 1999).

Os coliformes fecais são indicadores específicos e apresentam elevada correlação positiva com a contaminação fecal por animais de sangue quente; a alimentação por filtração efetuada pelos mexilhões concentra os microorganismos presentes no ambiente marinho. Várias críticas e algumas desvantagens são apontadas quanto ao uso dos coliformes como indicadores de poluição fecal, em ambientes hídricos, devido a sua baixa tolerância à toxicidade da água do mar ou salgada, bem como, ao procedimento de cloração em relação a alguns patógenos resistentes (Pádua, 2003).

A enumeração de coliformes totais em água é menos representativa como indicação de contaminação fecal que a enumeração de coliformes termotolerantes ou Escherichia coli. No entanto, sua enumeração é utilizada em indústrias alimentícias, indicando poluição pré-sanitização, contaminação pós-sanitização ou pós-processo, evidenciando práticas de higiene e sanitização aquém dos padrões requeridos para o processamento de alimentos (Pádua, 2003).

No Brasil, a Agência Nacional da Vigilância Sanitária (ANVISA), órgão que regulamenta os padrões microbiológicos em alimentos, através da resolução RDC $\mathrm{n}^{0} 12$, de 2 de janeiro de 2001, preconiza que os moluscos bivalves in natura, resfriados ou congelados e que não serão consumidos crus, apresentem-se livres de Salmonella sp. em 25 g e limita, em $10^{3}$ NMP, a contagem de Staphylococcus coagulase positiva/ g de pescado (Brasil, 2001).

Outros patógenos como o Clostridium perfringens, Shigella, Yersinia enterocolitica, Listeria monocytogenes e Campylobacter jejuni representam risco. No 
entanto, práticas adequadas de manipulação pós captura podem reduzir a frequência de doenças. $\mathrm{O}$ risco de infecções alimentares associados a estes microorganismos pode ser considerado baixo quando comparado ao risco de uma infecção viral ou por víbrios. (Estados Unidos, 1992). 


\section{QUALIDADE FÍSICO-QUÍMICA DE MEXILHÕES Perna perna CULTIVADOS E COMERCIALIZADOS IN NATURA NO LITORAL NORTE DE SÃO PAULO}

\subsection{Resumo}

O pescado apresenta fatores intrínsecos importantes, que exercem influência sobre sua qualidade; dentre eles destacam-se; o pH da carne post mortem e a presença de substâncias nitrogenadas não protéicas. Visando determinar a qualidade para comercialização, através do monitoramento dos componentes físico-químicos, do bivalve Perna perna cultivado na região de Ubatuba, SP., foram eleitas três áreas de cultivo, a saber; praia do Engenho da Almada, praia da Barra Seca e costão do Cedro, onde os mexilhões foram coletados, no período de novembro de 2002 a março de 2003. Foram determinados: composição centesimal (umidade, proteína, lipídeos, cinza e carboidratos), rendimento, nitrogênio não protéico (NNP), bases nitrogenadas voláteis totais (BNVT), pH e trimetilamina (TMA). Os resultados mostraram que o mexilhão Perna perna é uma fonte protéica, apresenta baixo teor lipídico $(1,1 \%)$ e calórico $(62,7$ Kcal/ $100 \mathrm{~g}$ ) e seus constituintes químicos variam em função da sazonalidade e do local de origem; apresenta bom rendimento (34,9\%) e está em conformidade com os padrões do Regulamento de Inspeção Industrial e Sanitária dos Produtos de Origem Animal (RIISPOA), para pescado, exceção do mês de fevereiro, quando o valor de TMA encontrado (6,9mg N/100g) superou a legislação vigente. Os mexilhões comercializados em Ubatuba, até 24 horas após coleta, apresentaram-se com qualidade satisfatória para 
consumo, viabilizando a continuidade desta atividade no litoral Norte paulista. Apresentaram uma vida útil de 5 dias, sob a temperatura de $10^{\circ} \mathrm{C}( \pm 1)$, conforme aferido pelos dados obtidos para BNVT e pH. Constatou-se também, a necessidade de novos estudos para definição de padrões de qualidade adequados a este molusco.

\subsection{Summary}

Seafoods presents important intrinsic factors that influence your quality, among them the $\mathrm{pH}$ in the post mortem meat and the presence of non-protein-nitrogen substances. Aiming to determine the quality for commercialization through of the monitoring the phisicochemistry components of the bivalve Perna perna cultivated in the city of Ubatuba, SP., three cultivation areas were chosen; Engenho da Almada and Barra Seca’s beaches and Cedro's coast. The mussels were collected from November, 2002 to March, 2003. The analysis determined were: proximal composition (moisture, protein, fat, ash and carbohydrate), yield, nitrogen-non-protein (NPN), total volatile basic nitrogen (TVBN), $\mathrm{pH}$ and trimethylamine (TMA). The results showed that the Perna perna mussel is a protein source, it presents low fat $(1,1 \%)$ and caloric $(62,7$ Kcal/ 100g). The mussels chemicals representatives vary in function of the season and place; it presents good yield (34,9\%) and conformity with the standard of the Regulamento de Inspeção Industrial e Sanitária dos Produtos de Origem Animal (RIISPOA), for fish, exception in February, when the TMA values founded overcame the effective legislation. Until 24 hours after collection, the Ubatuba's mussels marketed

presents satisfactory quality for consumption so, its possible the continuity of this activity in the São Paulo North coast. The mussels presented a shelf-life of 5 days, under the temperature of $10^{\circ} \mathrm{C}( \pm 1)$, accordingly the data obtained for BNVT and $\mathrm{pH}$. Were also evidenced, the need of new studies for definition of appropriate standards of quality to this mollusk. 


\subsection{Introdução}

Pode parecer inadequado discutir sobre o consumo de mexilhões vivos ou in natura, pois a melhor solução seria abater, processar e congelar este alimento. Este procedimento ofereceria maior segurança e um produto de melhor qualidade. Existem riscos de prejuízo econômico na prática do congelamento de ostras e outros moluscos, no entanto, quando se trata de mexilhões o prejuízo é menor e quanto a vieiras praticamente inexistente (Doré, 1941). Apesar do mínimo prejuízo quanto aos produtos congelados de mexilhões e a maior segurança no consumo destes produtos, existem controvérsias, tais como, o peso de venda e a preferência de restaurantes favorecendo o consumo do produto fresco, não congelado. Os consumidores estão, constantemente, alegando a preferência por pescado fresco, escritores de culinária, invariavelmente, especificam que os produtos congelados são inferiores, bem como, as redes de supermercados promovem os benefícios de seus balcões de pescado fresco. No entanto, os produtos manejados e processados, adequadamente, têm vida útil mais extensa, conservando-se mais frescos que a maioria do pescado que nunca foi congelado, principalmente, por tratar-se de um alimento de alta perecibilidade (Doré, 1941).

Apesar das vantagens do produto processado, a comercialização dos mexilhões cultivados no litoral Norte paulista é, quase na sua totalidade, realizada na forma fresca, ou melhor, de mexilhões vivos, como solicitado pela legislação vigente. Portanto, sua qualidade deve ser pesquisada, visando a segurança do consumidor e garantindo a demanda.

A perda na qualidade dos alimentos pode ser causada por uma gama de reações, principalmente, físicas e químicas, e devida a ação de enzimas e microorganismos. Para os alimentos frescos, as alterações primárias podem ser devidas ao metabolismo e crescimento bacteriano, resultando em possíveis alterações no $\mathrm{pH}$ e formação de compostos tóxicos, gás, muco e odor desagradável; oxidação dos lipídeos e de

pigmentos, resultando em sabor e aroma desagradáveis, e formação de compostos com efeitos biológicos adversos ou descoloração (Huis in’t Veld, 1996). A deterioração do alimento pode ser óbvia, por exemplo, produto injuriado, com visível crescimento 
microbiano ou formação de muco. Contudo, quando a deterioração é devido a alterações na textura ou pelo desenvolvimento de sabor desagradável, causado por reações bioquímicas e microbianas, ou seja, mecanismos implícitos, estes podem dificultar a identificação. Conseqüentemente, a avaliação da qualidade, direta ou indiretamente, é aferida pela análise sensorial, embora, as análises bioquímicas ou em menor extensão, microbiológicas, sejam mais acessíveis, objetivas e convenientes. A análise microbiológica clássica, especialmente de alimentos perecíveis in natura, também é de limitado valor, pois o tempo necessário para prognóstico, normalmente, supera a vida útil do produto.

A carne de pescado possui vida comercial muito restrita e variável. O local e as condições de cultivo, a época do ano na qual ocorre a coleta, o método de coleta e a manipulação pós captura atuam diretamente sobre a sua qualidade (Botta, 1994). Para Spinelli et al. (1964), um método objetivo ideal para mensuração da qualidade em pescado, fresco ou congelado, deveria correlacionar a qualidade com o tempo e temperatura de estocagem pós captura, fornecendo uma base para estimar sua vida útil.

Os padrões de qualidade do pescado e derivados estão baseados na análise de compostos como bases nitrogenadas voláteis totais (BNVT) e trimetilamina (TMA), e segundo o Ministério da Agricultura, Pecuária e Abastecimento, que regulamenta o RIISPOA, os níveis de BNVT devem ser inferiores a 0,03 g de nitrogênio por 100 g de carne e bases voláteis terciárias inferiores a 0,004g N, em $100 \mathrm{~g}$ (para atestar frescor ao produto); para pH da carne os níveis externos aceitáveis são inferiores a 6,8 e internos a 6,5. Determinam também o frescor, a reação negativa para gás sulfídrico e de indol, com exceção de alguns crustáceos onde o limite é de no máximo 4g/ 100g de carne (Brasil, 1980).

A determinação das BNVT é um método relativamente simples e, conseqüentemente, largamente utilizado para avaliar, quimicamente, o frescor de um alimento marinho (Botta, 1994; Amanajás, 1985). Entretanto, Antanacopoulos \& Vincke (1989) e Rodríguez-Jérez et al. (2004), afirmam que a determinação das BNVT deveria ser um método de rotina, somente utilizado para determinar se o pescado é próprio para o consumo, pois esta análise não permite a identificação de estágios iniciais de frescor 
do pescado. Em pescado marinho, as BNVT primariamente incluem a TMA, a amônia e a dimetilamina (DMA). A determinação química do nível de TMA está entre os métodos mais investigados para a mensuração da qualidade de alimentos marinhos e tem sido apontada como um índice útil de frescor para muitas dessas espécies (Eiroa, 1980; Hebard et al., 1982).

Em adição à determinação do BNVT e TMA, a degradação de nucleotídeos post mortem, a formação de aminas biogênicas e etanol têm também sido utilizadas para mensurar o frescor. E, embora as aminas biogênicas, particularmente a histamina, sejam de grande interesse, do ponto de vista da segurança alimentar, uma das principais desvantagens de usá-las como indicadoras de frescor é que a simples ausência destas não, necessariamente, indica boa qualidade do produto (Botta, 1994).

Aferir frescor ao pescado é muito importante na indústria, para elaboração de produtos de alta qualidade. Entre outros métodos, a mensuração dos nucleotídeos produzidos pela decomposição do trifosfato de adenosina (ATP) é considerado como o indicador mais confiável de frescor (Ogawa \& Maia, 1999; Rodríguez-Jérez et al., 2004). O método de separação e quantificação dos nucleotídeos apresenta a vantagem de evitar as interferências dos componentes adicionais dos mariscos e permite a soma de todos os catabólitos, facilitando a apresentação dos resultados como percentagem do total. Este índice, denominado valor K, foi proposto, primeiramente, por Saito et al. (1959) e recomendado por Hiltz et al. (1971); Ehira \& Uchiyama, (1987); Botta, (1994); Ogawa \& Maia, (1999) e Davis (1999).

A hipoxantina (Hx) é um dos produtos da decomposição do ATP e a sua determinação também foi proposta como indicador do grau de frescor para espécies de pescado, tipicamente, acumuladoras desta substância (Hiltz et al., 1971). Segundo Gram \& Huss (1996), o desenvolvimento da Hx em muitas espécies de pescado é paralela à produção da TMA.

Quando comparados a outros tipos de pescado, os moluscos apresentam em sua carne um teor relativamente elevado de carboidratos, o que, certamente, faz com que seu processo deteriorativo seja diferenciado dos demais produtos pesqueiros, trazendo à tona a necessidade de mais estudos e uma legislação específica para estes organismos. 
Devido a complexidade do processo de decomposição do pescado, torna-se inviável o uso de um método isolado na avaliação de sua qualidade. A determinação da qualidade do pescado deve ser criteriosa, visto que há inúmeras espécies de pescado e o curso da deterioração é diferente quando comparamos espécies, indivíduos de uma mesma espécie e até partes de um mesmo indivíduo (Ogawa \& Maia, 1999).

\subsection{Material e métodos}

\subsubsection{Pontos de coleta}

Os pontos de coleta estudados encontram-se localizados nas praias da Barra Seca

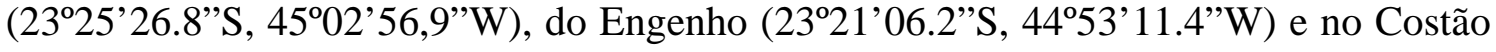
do Cedro (233' 45.5'”S, 4509'32.9”W), como pode ser visualizado na Figura 1, e que foram classificados como área de ocupação primária, ou seja que apresentam condições favoráveis ao cultivo de mexilhões (Marques \& Pereira, 1989).

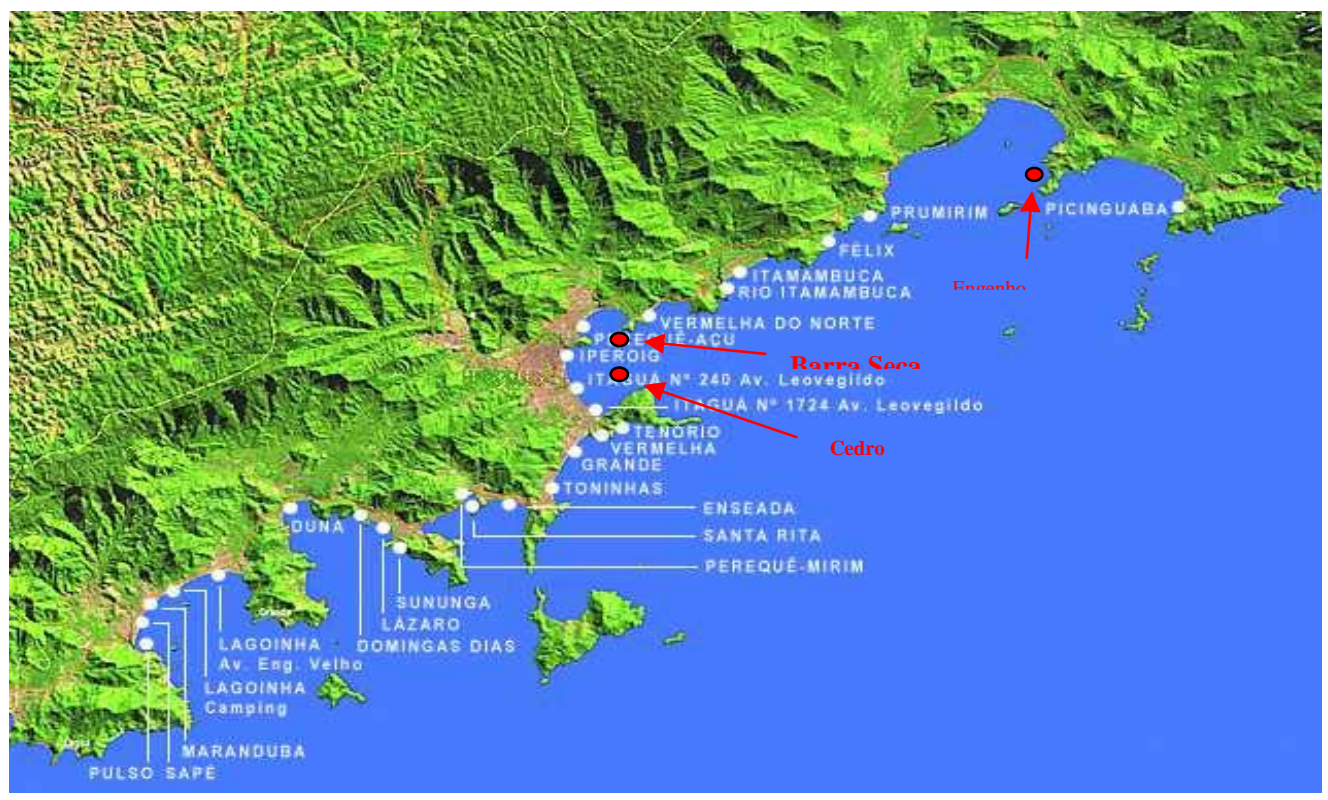

Figura 1 - Mapa dos pontos de coleta analisados em Ubatuba, SP 


\subsubsection{Procedimento de coleta}

Cerca de $10 \mathrm{Kg}$ de mexilhões, da espécie Perna perna, foram coletados, mensalmente, de cada um dos pontos de cultivo, no período de novembro de 2002 a março de 2003, totalizando 5 coletas. A etapa de coleta dos mexilhões encontra-se

ilustrada na Figuras 2. Estes foram submetidos ao processo de desdobre, na qual o próprio produtor faz a retirada dos cachos, separando-os da fauna acompanhante, retirando cracas e parasitas. Posteriormente, foram lavados com água do mar, no caso da praia do Engenho e com água tratada pela Secretaria de Energia, Recursos Hídricos e Saneamento (SABESP), nos outros dois pontos (Barra Seca e costão do Cedro), efetuando assim a limpeza superficial das valvas. Esta manipulação pós-coleta pode ser visualizada na seqüência de fotos (Figuras 3 e 4). Após este processo, os mexilhões foram acondicionados em sacos de ráfia, como apresentado na Figura 5, e transportados em vasilhame isotérmico contendo gelo comercial filtrado, na proporção de 3:1 (mexilhão/gelo), sem contato direto entre estes, evitando-se assim a morte dos bivalves. Chegando ao setor de Processamento de Alimentos do Departamento de Agroindústria, Alimentos e Nutrição, as amostras foram armazenadas a granel, em refrigerador vertical doméstico, em temperatura média de $10^{\circ} \mathrm{C} \pm 1^{\circ} \mathrm{C}$.
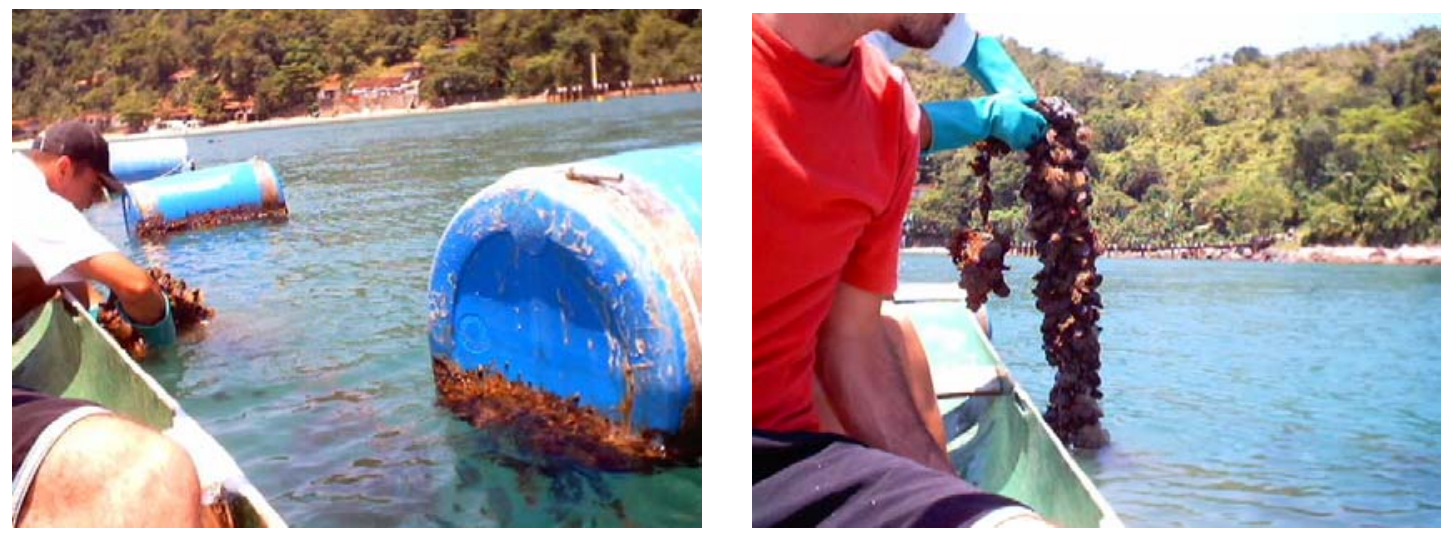

Figura 2 - Coleta dos mexilhões das cordas de cultivo (Long line) 

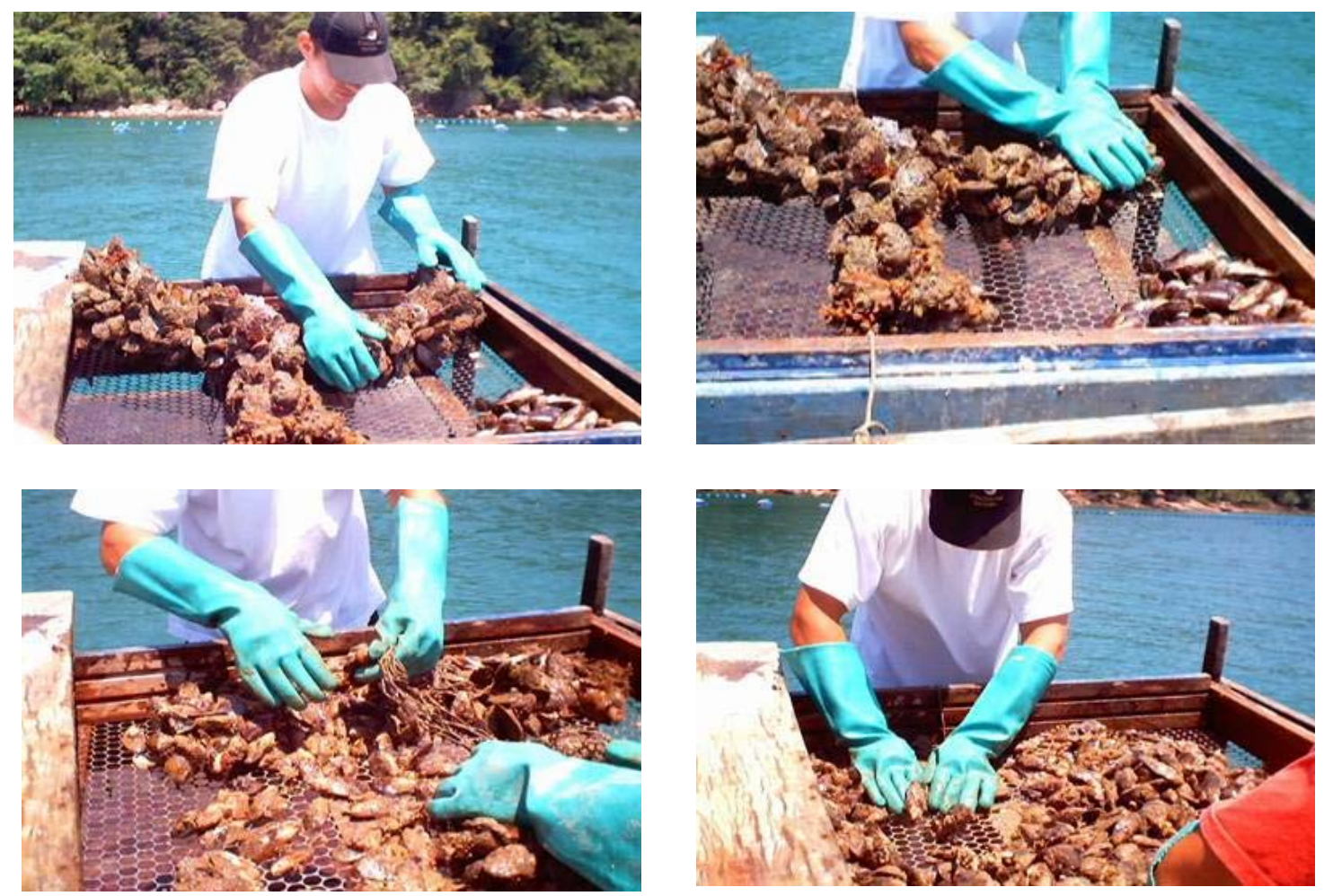

Figura 3 - Etapas da operação de desdobre
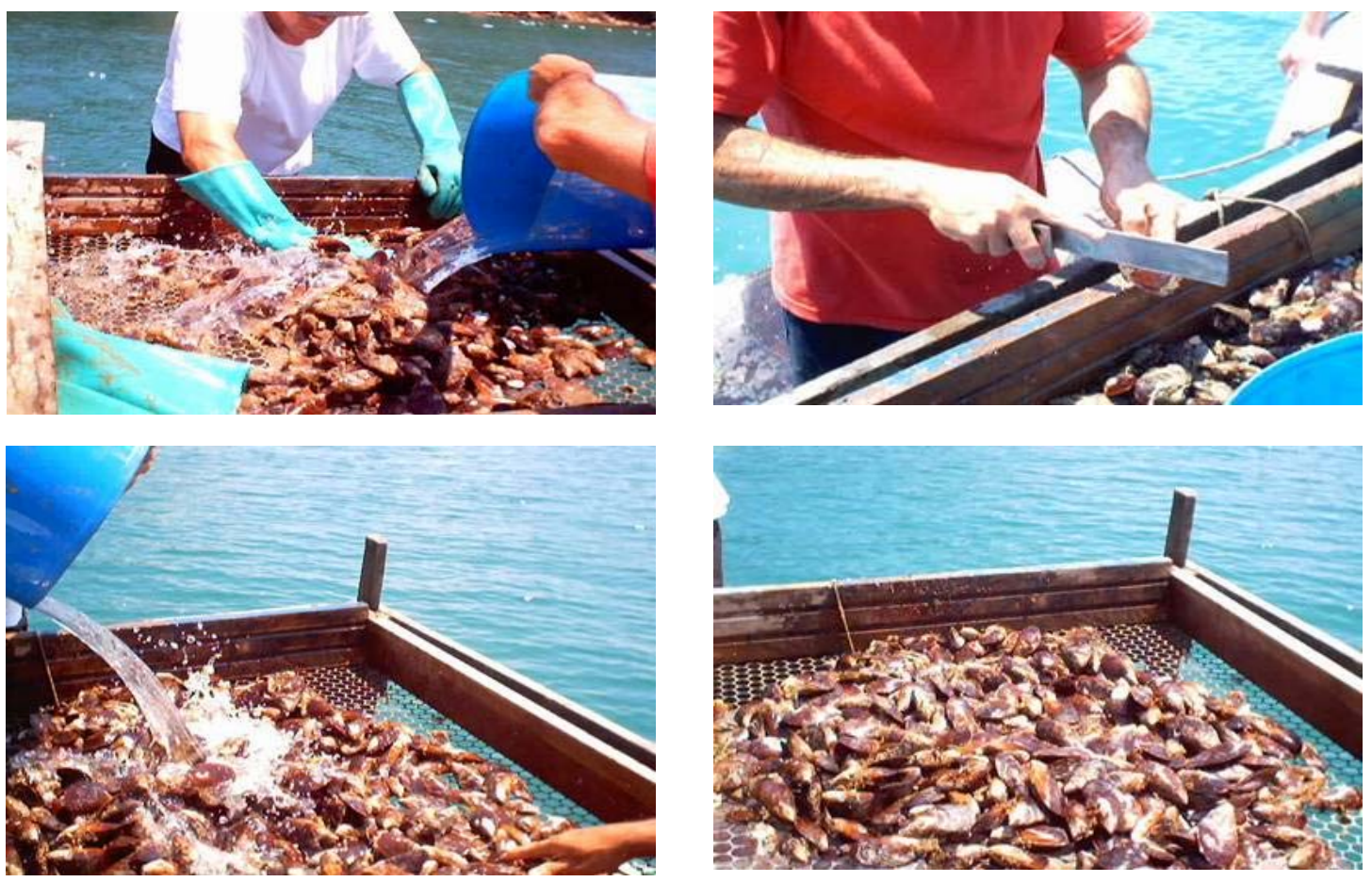

Figura 4 - Etapas da limpeza e mexilhões limpos 


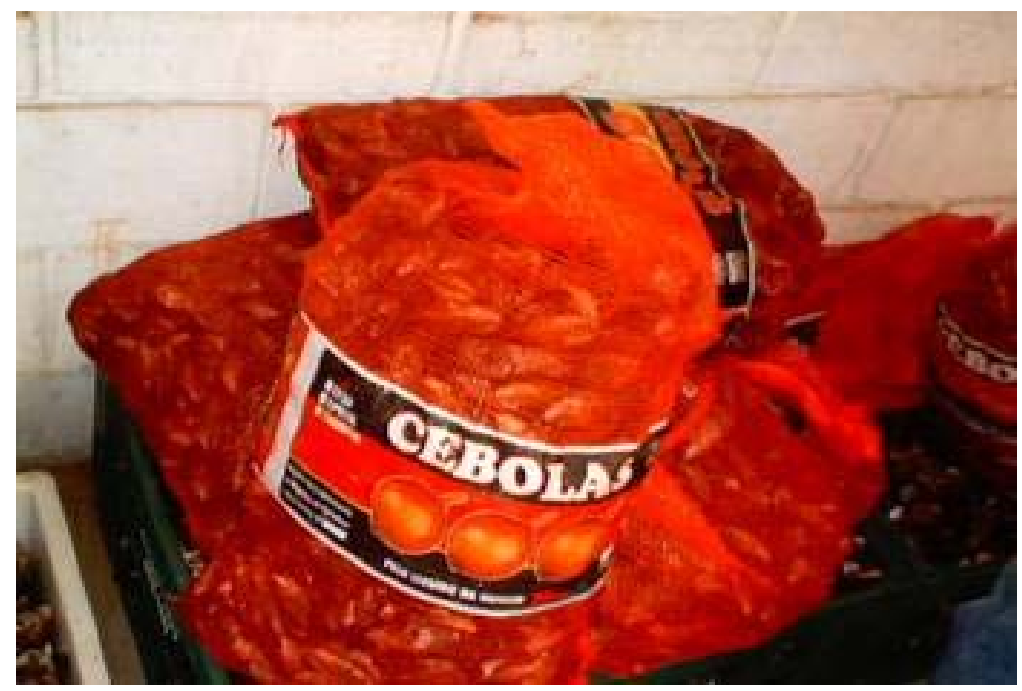

Figura 5 - Mexilhões acondicionados em sacos de ráfia, para transporte

\subsubsection{Análises físico-químicas}

As análises físico-químicas dos mexilhões in natura, a saber, determinação do $\mathrm{pH}$, bases nitrogenadas voláteis totais (BNVT) e nitrogênio não protéico (NNP), bem como; a composição centesimal (umidade, proteína, lipídeos, carboidratos e cinza) foram realizadas, em triplicatas, no setor de Processamento de Alimentos do Departamento de Agroindústria, Alimentos e Nutrição da ESALQ/ USP. A determinação do teor de trimetilamina (TMA) procedeu-se no Laboratório Regional de Apoio Animal do Ministério da Agricultura, Pecuária e Abastecimento (LARA/ MAPA), no setor de análises físico-químicas, um dia após a coleta e foi realizada em duplicatas. As análises de pH e de BNVT foram realizadas nos mexilhões coletados em janeiro, fevereiro e março, em triplicatas, tendo início 24h após a coleta das amostras e foi conduzida até que os resultados atingissem o limite para BNVT estipulado pela legislação vigente, de 30mg N/ 100g de pescado (Brasil, 1980). 


\subsubsection{Análise centesimal}

Excetuando-se a determinação de carboidratos que ocorreu através da fração NIFEXT, as demais análises (umidade, proteína bruta, lipídeos e cinza) seguiram de acordo com Hungerford (1995). A umidade foi determinada através do método gravimétrico, em estufa a $105^{\circ} \mathrm{C}$ até peso constante. O teor de proteína bruta pelo método Kjeldahl, e conversão em proteína multiplicando o valor obtido pelo fator 6,25. Os lipídeos foram determinados por extração com hexano, pelo método de Soxhlet e o teor de cinza pelo método gravimétrico, em mufla a $550^{\circ} \mathrm{C}$ e incineração da matéria orgânica em bico de Bunsen.

\subsubsection{Valor calórico}

Determinado segundo Latham, (2002), multiplicando-se o teor lipídico por 9 e os teores de proteína e de carboidratos por 4.

\subsubsection{Biometria dos mexilhões}

Medição do comprimento das valvas com paquímetro, utilizando-se 100 valvas de cada amostragem.

\subsubsection{Rendimento do mexilhão}

Determinado pela diferença entre o peso do mexilhão inteiro (na concha) e o peso da carne do mexilhão + líquido intravalvar (sem as valvas). Utilizando-se de um lote de 500 g de mexilhão de cada área de cultivo. 


\subsubsection{Nitrogênio não protéico}

Determinado por precipitação das proteínas musculares com ácido tricloroacético (TCA), seguida de avaliação do NNP presente no extrato TCA, através do método Micro Kjeldahl, de acordo com Hungerford.(1995).

\subsubsection{Bases nitrogenadas voláteis totais}

Determinação pelo método adotado pelo Instituto de Fomento Pesqueiro do Chile -IFOP, descrito por Morga (1975). Onde, adicionou-se, a 50 g do músculo + líquido intravalvar homogeneizados em liquidificador, $150 \mathrm{~mL}$ de TCA 5\%; homogeneizou-se por $1 \mathrm{~min}$; deixando em repouso por $15 \mathrm{~min}$. Após este período, filtrou-se em papel filtro, ajustando-se o volume a $250 \mathrm{~mL}$ em balão volumétrico, lavando o filtro com água destilada. Em um balão de destilação adicionou-se $20 \mathrm{~mL}$ do filtrado, $150 \mathrm{~mL}$ de água destilada e 2 g de MgO; o balão foi fechado e submetido ao aquecimento. O destilado foi recebido em erlenmeyer contendo $20 \mathrm{~mL}$ de ácido bórico a 1\% com indicador misto (vermelho de metila e verde de bromocresol); destilou-se aproximadamente $150 \mathrm{~mL}$ e procedeu-se à titulação com $\mathrm{HCl}$ 0,02 N, até viragem da cor

azul para rosa. O cálculo da quantidade de Nitrogênio volátil/ 100 gramas da amostra foi obtido pela fórmula:

mg de N volátil/ 100 g de pescado = G X N x 14 100, onde:

\section{P}

$\mathrm{G}$ = volume de $\mathrm{HCl}$ 0,02 N gasto;

$\mathrm{N}=$ normalidade do $\mathrm{HCl}$;

$\mathrm{P}=$ peso do pescado na alíquota destilada (4g).

\subsubsection{7 pH}

Determinado por leitura em potenciômetro digital Digimed, utilizando 50g da amostra homogeneizada com $10 \mathrm{~mL}$ de água destilada (Brasil, 1981). 


\subsubsection{Trimetilamina}

Para esta determinação o nitrogênio protéico foi precipitado com TCA e o filtrado tratado com solução de formaldeído, que reage com as aminas, exceto com a TMA. Então, o filtrado foi alcalinizado e a TMA destilada por arraste a vapor, recebida em solução de ácido bórico e titulada com solução de ácido padronizada, segundo o método proposto por Brasil (1981).

\subsubsection{Análise estatística}

Os constituintes químicos, bem como, os dados de tamanho e rendimento foram analisados pelo programa estatístico SANEST, utilizando-se da análise de variação de classes múltiplas balanceadas, ao acaso, e submetidos a teste de variância e de Tukey. Todos os dados aqui levantados foram correlacionados utilizando-se do pacote estatístico SAS (Versão 802).

\subsection{Resultados e discussão}

\subsubsection{Análises físico-químicas}

\subsubsection{Composição centesimal}

A Tabela 1 mostra a composição centesimal e o valor calórico médio dos mexilhões coletados de novembro de 2002 a março de 2003. Os valores apresentados são a média geral referente aos mexilhões obtidos dos três distintos pontos de cultivo. 
Tabela 1. Composição centesimal e valor calórico dos mexilhões cultivados em Ubatuba, SP, variação sazonal

\begin{tabular}{ccccccc}
\hline Meses & $\begin{array}{c}\text { Umidade } \\
(\mathrm{g} / 100 \mathrm{~g})\end{array}$ & $\begin{array}{c}\text { Proteína } \\
(\mathrm{g} / 100 \mathrm{~g})\end{array}$ & $\begin{array}{c}\text { Lipídeos } \\
(\mathrm{g} / 100 \mathrm{~g})\end{array}$ & $\begin{array}{c}\text { Cinza } \\
(\mathrm{g} / 100 \mathrm{~g})\end{array}$ & $\begin{array}{c}\text { Carboidratos } \\
(\mathrm{g} / 100 \mathrm{~g})\end{array}$ & $\begin{array}{c}\text { Calorias } \\
\text { Kcal/100g }\end{array}$ \\
\hline Novembro & $81,41 \mathrm{c}$ & $10,73 \mathrm{a}$ & $1,49 \mathrm{a}$ & $1,58 \mathrm{~d}$ & $4,85 \mathrm{~b}$ & 75,69 \\
Dezembro & $85,37 \mathrm{a}$ & $8,94 \mathrm{~b}$ & $1,06 \mathrm{c}$ & $1,68 \mathrm{c}$ & $2,95 \mathrm{c}$ & 57,10 \\
Janeiro & $83,45 \mathrm{~b}$ & $6,91 \mathrm{c}$ & $0,99 \mathrm{c}$ & $1,43 \mathrm{e}$ & $7,22^{\mathrm{a}}$ & 65,43 \\
Fevereiro & $84,96 \mathrm{a}$ & $9,28 \mathrm{~b}$ & $1,00 \mathrm{c}$ & $2,00 \mathrm{~b}$ & $2,76 \mathrm{c}$ & 53,36 \\
Março & $83,65 \mathrm{~b}$ & $9,6 \mathrm{~b}$ & $1,16 \mathrm{~b}$ & $2,25 \mathrm{a}$ & $3,34 \mathrm{c}$ & 62,20 \\
Desvio Padrão & 2,07 & 1,56 & 0,23 & 0,26 & 1,86 & 8,59 \\
\hline
\end{tabular}

Nota: médias seguidas da mesma letra não diferem entre si ao nível de $5 \%$ de probabilidade

\subsection{Umidade}

Os valores médios para umidade encontrados nesta pesquisa, 84,19g /100g, 83,16g /100g e 83,94g /100g para os mexilhões cultivados nas praias do Engenho e da Barra Seca e no costão do Cedro, respectivamente, apresentaram-se superiores aos encontrados por Tavares et al. (1998), da ordem de 72,12g /100g para a mesma espécie. No entanto, esta diferença pode ser explicada pelas distintas metodologias utilizadas no processo de desconchamento dos mexilhões, onde, os autores, supra citados, lançaram mão de uma pré-cocção para promover a abertura das valvas, enquanto na presente pesquisa estes foram abertos ainda vivos, cortando-se o músculo adutor. Na base de dados de nutrientes do Departamento de Agricultura dos Estados Unidos (USDA da sigla em inglês) encontra-se que o mexilhão azul Mytilus edulis L. (in natura) apresenta 81g /100g de umidade e 61g /100g após cocção (Base de dados..., 2002). Confirmando que a variação no teor de umidade pode estar relacionada ao método de preparo e, no caso, a metodologia de obtenção da amostra. 
Schramm (1993) obteve valores de umidade entre 75 e 82g /100g para mexilhões pré-cozidos em água fervente por 5 min. Enquanto para Magalhães (1985) o valor para este componente variou entre 78,30g/100g a 89,77g /100g .

No mês de dezembro, detectou-se um maior teor médio de umidade (85,37g /100g), em concordância com Gelli (1992) e Magalhães (1985), mas contrariando os dados apresentados por Tavares et al. (1998). No entanto, estes mesmos autores, afirmaram que os teores de umidade apresentam uma relação inversa aos valores de lipídeos. Fato também constatado nesta pesquisa, onde se observou uma correlação negativa alta entre estes componentes. Os teores médios encontrados para estes componentes são apresentados nas Tabelas 1. O maior teor de umidade detectado em dezembro deve-se aos mexilhões do costão do Cedro, pois para os outros pontos, os maiores teores ocorreram em fevereiro. No mês de dezembro foi encontrada diferença significativa entre os teores de umidade dos mexilhões de todos os cultivos, no nível de 1 e 5\% de significância. O teor de lipídeos foi, significativamente, menor nos mexilhões provenientes do cultivo do costão. Considerando o fator mês da coleta, não houve diferença significativa entre o teor de umidade dos mexilhões coletados em dezembro e em fevereiro.

O teor de umidade também apresentou correlação negativa com os teores de proteína e carboidratos. Para este último componente esta relação já era esperada, visto o conteúdo hídrico representar a maior percentagem na constituição dos moluscos e o carboidratos ter sido calculado pela fração NIFEXT. No entanto, quando se considerou o local de cultivo, só houve correlação entre os teores de umidade e protéico para os mexilhões provenientes da praia do Engenho e, quanto aos teores de umidade e carboidratos, não houve correlação.

Os menores teores de umidade ocorreram no mês de novembro para todas as amostras analisadas, o que também foi diagnosticado por Gelli (1992) e Magalhães (1985). Esta última autora, estudando machos e fêmeas, verificou que a percentagem de umidade não diferia, estatisticamente, entre os sexos. Entretanto, a autora constatou diferenças entre os diferentes estádios do ciclo reprodutivo em um mesmo sexo, 
afirmando, que o decréscimo da quantidade de água dos tecidos, principalmente nas fêmeas, acompanha o aumento da atividade reprodutiva.

Portanto, a determinação dos constituintes químicos é importante, não somente do ponto de vista nutricional, mas também ecológico.

\subsection{Proteína}

Para a proteína, o valor médio encontrado foi de 9,09g /100g, não havendo diferença significativa entre os mexilhões dos diferentes cultivos nos níveis de 1\% e 5\% de probabilidade. Tavares et al. (1998) encontraram valores superiores para proteína (próximos a 20g /100g) e demais frações, o que pode ser explicado pela distinta

metodologia de preparo das amostras, como já comentado anteriormente no item 3.5.1.1.1.

Os valores protéicos encontrados neste trabalho estão de acordo com Gelli (1992) e Magalhães (1985), que encontraram valores de 6,7 a 9,5g /100g e 9,68g /100g, respectivamente. Sendo que, esta última autora citada, trabalhou com mexilhões depurados, ou seja, eliminou o conteúdo intestinal, evitando possível interferência na avaliação do teor protéico destes animais. No estudo de Magalhães (1985) foi constatado que, em média, 9,68g /100g do peso fresco ou 58,16g /100g do peso seco do molusco Perna perna corresponde a fração protéica e que, a média do teor protéico para machos é, significativamente, menor que para fêmeas.

No presente estudo o maior valor médio para proteína foi encontrado no mês de novembro (10,73g /100g), não havendo diferença significativa para os mexilhões provenientes das distintas praias nos níveis de 1\% e 5\%, como pode ser visualizado na Tabela 1 e, concordando com o que foi discutido por Schramm (1993) e Magalhães (1985). Esta última autora verificou que tanto machos quanto fêmeas da espécie Perna perna apresentam maior teor protéico na fase IIIA do ciclo sexual, fase esta, em que os folículos apresentam-se repletos de gametas. Na presente pesquisa, não foi possível correlacionar estas informações devido ao estudo se limitar a 5 meses e por não ter-se analisado as gônadas. Os valores médios obtidos no mês de novembro, para os 
mexilhões cultivados nas praias do Engenho da Almada, da Barra Seca e do costão do Cedro foram, respectivamente, 11,04g /100g; 10,27g /100g e 10,88g /100g. Já, para os mexilhões da Barra Seca, a maior média equivale a coleta de dezembro $(10,47 \mathrm{~g} / 100 \mathrm{~g})$.

O menor conteúdo protéico $(6,31 \mathrm{~g} / 100 \mathrm{~g})$ refere-se a amostragem do costão do Cedro no mês de janeiro, período em que todas as amostras apresentaram menor porcentagem de proteína (6,98g /100g e 7,44g /100g, respectivamente, para as praias do Engenho e da Barra Seca). Estes valores não diferiram, estatisticamente, ao nível de 1\% de probabilidade. De acordo com Magalhães (1985), são grandes as dificuldades para se comparar resultados de teor protéico, mesmo entre animais da mesma espécie, justificadas pelas distintas regiões de coleta destes animais, os diferentes estádios do ciclo reprodutivo, bem como, as diversas metodologias utilizadas para a determinação deste componente. Esta pesquisa vem confirmar a existência da variação do teor protéico em função dos locais de origem destes organismos, bem como, a existência de uma correlação positiva alta entre os teores de proteína e lipídeos. Considerando-se o local de origem, apenas os mexilhões provenientes da Barra Seca não apresentaram correlação entre os teores de proteína e de lipídeos.

\subsection{Lipídeos}

O teor lipídico não sofreu grandes oscilações ao longo desta pesquisa, como pode ser visto na Tabela 3. Os menores valores médios foram encontrados nos meses de dezembro, janeiro e fevereiro; 1,06g /100g, 0,99g /100g e 1g /100g , respectivamente, não ocorrendo diferença estatística para estes valores; o maior teor médio encontrado foi de $1,49 \mathrm{~g} / 100 \mathrm{~g}$ no mês novembro. O maior teor lipídico encontrado nesta pesquisa $(1,66 \mathrm{~g} / 100 \mathrm{~g})$ está relacionado aos mexilhões cultivados na praia do Engenho da Almada e o menor $(0,61 \mathrm{~g} / 100 \mathrm{~g})$ ao costão do Cedro, referentes aos meses de novembro e dezembro, respectivamente. Os mexilhões coletados na Barra Seca apresentaram um teor lipídico constante, diferindo, estatisticamente, apenas no mês de fevereiro quando este se reduziu a $1,08 \mathrm{~g} / 100 \mathrm{~g}$. 
Magalhães (1985) encontrou o maior teor protéico na fase IIIA do ciclo sexual destes organismos, ou seja, a fase repleta de gametas; a presente pesquisa constatou que, provavelmente, no mês de novembro, todos os mexilhões apresentavam-se em gametogênese e que, em dezembro, os mexilhões coletados da Barra Seca também se apresentavam neste estádio.

Segundo Ackman (1999), o conteúdo lipídico de mariscos pode estar no intervalo de 1 a 2g /100g e, uma razão básica apontada pelo autor para este reduzido conteúdo em lipídeos, é que os bivalves armazenam seus excedentes ou reservas de energia na forma de glicogênio e não como gordura. Constatou-se, no presente estudo, que os mexilhões Perna perna apresentam maior quantidade de carboidratos que lipídeos, o que pode ser confirmado pelos dados apresentados na Tabela 1.

\subsection{Cinza}

A média geral encontrada para este componente foi 1,79g /100g. Verificou-se que este não sofreu grandes oscilações, apresentando o valor mínimo de 1,43g /100g em janeiro, e máximo de 2,25g /100g em março, como demonstra a Tabela 1 . O maior teor encontrado refere-se aos mexilhões do costão do Cedro no mês de março (2,39g /100g). Enquanto, o menor teor encontrado para este componente $(1,25 \mathrm{~g} / 100 \mathrm{~g})$ refere-se à amostragem proveniente da praia da Barra Seca, no mês de janeiro. No mês de novembro, não houve diferença significativa para este constituinte, levando-se em conta os diferentes locais de coleta estudados. Os mexilhões provenientes da praia do Engenho da Almada apresentaram teores de cinza similares durante os meses de dezembro, novembro e janeiro (1,68g /100g; 1,66g /100g e 1,53g/100g, respectivamente); os provenientes da Barra Seca, em dezembro (1,30g /100g) e janeiro (1,25 g /100g), todos ao nível de $1 \%$ de probabilidade.

A quantidade de cinza apresentou correlação negativa com os valores para carboidratos, mas considerando o fator praias, ou seja, o local de origem dos organismos, esta correlação não é clara. 


\subsection{Carboidratos}

Os moluscos apresentam, em sua carne, maior teor de carboidratos e menor de nitrogênio total, quando comparados aos peixes e crustáceos. Segundo Jay (1994), os carboidratos são encontrados, principalmente, na forma de glicogênio. Nesta pesquisa, como apresentado na Tabela 1, o maior valor médio para carboidratos foi encontrado em janeiro $(7,22 \mathrm{~g} / 100 \mathrm{~g})$ e os menores em dezembro $(2,95 \mathrm{~g} / 100 \mathrm{~g})$, fevereiro $(2,76 \mathrm{~g} / 100 \mathrm{~g})$ e março (3,34g /100g), quando não diferiram, estatisticamente, ao nível de $1 \%$ de probabilidade. Discordando, em parte, dos resultados de Gelli (1992), que notificou valores mínimos para este constituinte de dezembro a fevereiro. No entanto, pode-se observar que a menor média no mês de dezembro representa o teor mínimo de carboidratos detectados para as amostras do costão do Cedro (1,31g /100g), pois os mexilhões provenientes da praia do Engenho e da Barra Seca acusaram teores mínimos em fevereiro (2,67g /100g e 2,71g /100g, respectivamente). Excetuando-se as amostras de dezembro do costão do Cedro e da praia do Engenho, em janeiro, não houve diferença significativa no teor de carboidratos dos mexilhões coletados entre as distintas praias.

Segundo Schramm (1993) há flutuação sazonal no conteúdo deste componente em função do ciclo reprodutivo do mexilhão. $\mathrm{O}$ conteúdo de carboidratos, significativamente superior no mês de janeiro, pode estar associado à eliminação de gametas, visto que Marques (1998) afirma que este período do verão caracteriza-se como o pico da reprodução destes organismos. De acordo com Magalhães (1985), nos bivalves, são freqüentes as variações nos teores de carboidratos e lipídeos e, menos comumente, nos de proteínas, que se correlacionam, diretamente, com a atividade reprodutiva.

\subsubsection{Valor calórico}

De acordo com os dados obtidos no presente trabalho, o valor calórico médio de uma porção equivalente a 100 g do produto fresco é cerca de 62,76 Kcal. Estes valores 
apresentaram-se consistentes, visto que o pico (75,69 Kcal) coincidiu com o período de engorda destes organismos. A média dos valores caloríficos encontrados, ao longo desta pesquisa, são apresentadas na Tabela 1.

Levando-se em consideração os constituintes químicos, aqui analisados, pode-se constatar que o mexilhão é uma fonte protéica de reduzido conteúdo lipídico e calórico, ou seja, um alimento conveniente para o padrão de vida atual, que devido a tendência sedentária, exige uma menor ingestão calórica diária.

\subsubsection{Rendimento $\mathrm{x}$ tamanho}

Para a indústria de alimentos, o rendimento da matéria-prima pode determinar o lucro do empreendimento. Os mexilhões do cultivo da praia do Engenho diferiram significativamente dos demais, apresentando a menor média quanto ao rendimento (30,79\%), sendo que para os do costão do Cedro e da Barra Seca os rendimentos médios foram 36,47 e 37,52\%, respectivamente. Correlacionando o tamanho (comprimento) dos mexilhões provenientes dos diferentes cultivos, as amostras diferiram entre si em nível de 5\%, apresentando médias de 7,6; 5,63 a 6,2 cm referentes aos cultivos do Engenho, do costão e da Barra Seca. Marques (1998) sinaliza que no litoral paulista mexilhões costumam ser comercializados com $5 \mathrm{~cm}$ de comprimento, já que nesta região o crescimento, praticamente, se estabiliza nos $6 \mathrm{~cm}$. A presente pesquisa constatou que a até próximo aos $6,5 \mathrm{~cm}$ de comprimento, o rendimento se faz crescente e que a partir deste é minimizado.

Analisando a relação entre tamanho e rendimento, encontrou-se correlação negativa, pois os mexilhões do Engenho apresentaram maior tamanho das valvas e menor rendimento. Já, quando comparamos as variáveis tamanho e rendimento, considerando o fator meses, encontramos correlação positiva, pois o mês no qual se obteve maior tamanho médio $(6,6 \mathrm{~cm})$ também se obteve maior rendimento (36,96\%). Marques (1998) afirma que um dos fatores que afetam a produtividade é o peso das valvas que, à medida que os mexilhões crescem, podem aumentar proporcionalmente, 
porém, nem sempre os mexilhões apresentam um peso para a porção comestível proporcional ao comprimento.

Gomes et al. (1998), calculando o rendimento do mexilhão P. perna, propôs como índice de condição comercial mínimo 14,81\%, médio 21,64\% e máximo 40,32\% de rendimento. Afirmando que essas variações ocorrem, em função da sazonalidade. Os valores encontrados neste trabalho estão entre o médio e o máximo rendimento e, mostram-se próximos ao rendimento conseguido com peixes (ao redor de 30\%).

\subsubsection{NNP}

Segundo Haard (1999), o conteúdo de NNP dos alimentos marinhos é significativamente superior ao dos outros miossistemas alimentários; procede fundamentalmente do sarcoplasma e inclui aminoácidos, compostos de guanidina, compostos de amônio quartenário, aminas e uréia. Estes compostos têm funções específicas e influem no sabor característico do pescado e dos mariscos, além de atuarem nas etapas de degradação dos produtos pesqueiros.

Borgstrom (1962) salienta que o teor de NNP dos crustáceos e moluscos é maior que o dos peixes teleósteos, chegando a 20\% do nitrogênio total. No presente estudo constatou-se para o NNP dos mexilhões um valor médio de 14,90g /100g do nitrogênio total. A Tabela 2 apresenta os teores de NNP obtidos, 24 horas após as coletas dos mexilhões, para as distintas áreas de cultivo.

Tabela 2. Nitrogênio não protéico nos mexilhões, 24 horas pós-coleta

\begin{tabular}{ccccccc}
\hline $\begin{array}{c}\text { NNP } \\
(\mathrm{g} / \mathrm{100g})\end{array}$ & Novembro & Dezembro & Janeiro & Fevereiro & Março & $\begin{array}{c}\text { Desvio } \\
\text { Padrão }\end{array}$ \\
\hline Engenho & 1,72 & 1,30 & 0,89 & 1,05 & 1,13 & 0,30 \\
Barra Seca & 2,01 & 0,68 & 1,12 & 1,25 & 1,30 & 0,49 \\
Cedro & 1,85 & 0,78 & 1,41 & 1,45 & 1,30 & 0,34 \\
\hline
\end{tabular}


Os resultados médios obtidos para NNP nesta pesquisa, 24 horas após as coletas, variaram de 0,68g / $100 \mathrm{~g}$ a 2,01g /100g, sendo estes valores referentes aos mexilhões provenientes da praia da Barra Seca nos meses de novembro e dezembro, respectivamente. No mês de novembro, foram encontrados os maiores teores de NNP também para os provenientes dos outros cultivos, do Engenho 1,72g /100g e do costão do Cedro 1,85\%. As médias obtidas durante o período experimental para os mexilhões dos cultivos do Engenho, Barra Seca e costão do Cedro foram, respectivamente, $1,22 \mathrm{~g} / 100 \mathrm{~g}, 1,27 \mathrm{~g} / 100 \mathrm{~g}$ e $1,40 \mathrm{~g} / 100 \mathrm{~g}$.

Segundo Ludorf \& Meyer (1978), quando se instalam as alterações post mortem no pescado, os níveis de substâncias nitrogenadas são aumentados, principalmente, as não protéicas e estas, são os primeiros nutrientes a serem utilizados pelos microorganismos presentes no músculo do pescado. Considerando que os animais aqui estudados apresentavam-se vivos até o momento da análise para NNP, os índices aqui apresentados não correspondem aos compostos nitrogenados não protéicos utilizados

pelos microorganismos, visto que o músculo do pescado apresenta-se estéril até o momento da sua morte. Amanajás (1985) afirmou que o critério é não recomendar a determinação global do NNP como índice de frescor, mesmo porque não existem padrões estipulados legalmente para este fim.

\subsubsection{BNVT}

O pescado pode ser alterado por ação enzimática e bacteriana com produção de vários compostos nitrogenados, sendo os mais frequentes a amônia, a trimetilamina, a dimetilamina, e os ácidos voláteis, e os menos frequentes a monometilamina, putrescina, cadaverina, espermidina, propilamina, entre outros. Seu teor é dado pela determinação das bases voláteis, que aumenta em função da deterioração do produto, sendo a TMA a base que possui variações mais significativas.

A Tabela 3 mostra o comportamento das BNVT, a partir das 24 horas até 192 horas após as coletas dos mexilhões, para os diferentes pontos de coleta. 
Tabela 3. BNVT (mg/ 100g) nos mexilhões cultivados, amostrados de janeiro a março de 2003

\begin{tabular}{lcccccccc}
\hline & $24 \mathrm{~h}$ & $48 \mathrm{~h}$ & $72 \mathrm{~h}$ & $96 \mathrm{~h}$ & $120 \mathrm{~h}$ & $144 \mathrm{~h}$ & $168 \mathrm{~h}$ & $192 \mathrm{~h}$ \\
\hline \multicolumn{1}{c}{ JANEIRO } & & & & & & & & \\
Engenho & 8,9 & 12,9 & 13,6 & 13,1 & 14 & 19,9 & 38 & 59,45 \\
Barra Seca & 7,4 & 12,1 & 13,65 & 12,1 & 12,95 & 17,8 & 20,15 & 22,5 \\
Cedro & 8,9 & 12,57 & 13,05 & 27,8 & 33,8 & 37,8 & 60,1 & 82,55 \\
\multicolumn{1}{c}{ FEVEREIRO } & & & & & & & & \\
Engenho & 7,2 & 8,4 & 7,7 & 7 & 12,6 & 19,8 & - & - \\
Barra Seca & 6,3 & 7,5 & 4,9 & 5,4 & 10,7 & 8,6 & 14,35 & 38,2 \\
Cedro & 8,2 & 8,4 & 4,9 & 6,5 & 10,5 & 7,6 & 23,8 & 28,4 \\
\multicolumn{1}{c}{ MARÇO } & & & & & & & & \\
Engenho & 5,6 & 12,4 & 9,8 & 9,8 & 17,7 & 16,6 & 7,7 & 14,9 \\
Barra Seca & 6,1 & 9,1 & 14,2 & 11 & 17,5 & 19,8 & 28,7 & 29,3 \\
Cedro & 7 & 10,7 & 12,4 & 14,5 & 16,6 & 20,3 & 17 & 20,3 \\
\hline
\end{tabular}

Os valores médios encontrados neste trabalho para BNVT, 24 horas após as coletas dos mexilhões, variaram de 5,6mg/ 100g, no mês de março, na praia do Engenho a $11 \mathrm{mg} /$ 100g no mês de dezembro, no costão do Cedro. Estando todas as amostras em conformidade com a legislação, uma vez que o limite legal adotado em muitos países como Japão, Austrália, Argentina, Alemanha, incluindo o Brasil, é de 0,03 g de N/ 100g de carne. No entanto, teores ao redor de 60mg de BNVT são comuns em elasmobrânquios de qualidade sensorial e microbiológica aceitáveis (Brasil, 1980; Contreras Guzmán, 1994; Tavares et al., 1988).

Estes valores apresentados, correspondentes à qualidade do produto, 24 horas após a coleta, são de suma importância para os produtores e consumidores locais, visto que o produto não é (e não deve ser) comercializado fora deste período. Os produtores costumam, na maioria das vezes, retorná-lo ao ambiente marinho quando não comercializado em 24 horas; apenas alguns, congelam o produto após este período. 
Levando-se em conta os limites críticos estipulados para BNVT pela legislação brasileira e os resultados apresentados na Tabela 3, pode-se estabeler uma vida útil, sob refrigeração, de 6 a 7 dias para os mexilhões Perna perna in natura, se mantidos a temperatura de $10^{\circ} \mathrm{C}( \pm 1)$; com exceção dos mexilhões coletados em janeiro no costão do Cedro que atingiram $30 \mathrm{mg}$ de BNVT no quinto dia após a coleta. O manual on line Freshness, Quality and Safety in Seafoods (2004), indica uma vida útil para moluscos frescos, provenientes de águas quentes, de 8 a 12 dias sob temperatura de refrigeração $\left(0^{\circ} \mathrm{C}\right)$ e Antoniolli (1999), preconizou vida útil de 7 dias para mexilhões cozidos e armazenados a $4^{\circ} \mathrm{C} \pm 1^{\circ} \mathrm{C}$.

A maior velocidade de degradação dos mexilhões provenientes do costão do Cedro, no mês de janeiro, pode estar associada a um provável maior tempo de espera das amostras até o seu acondicionamento em gelo, ou seja, ao maior tempo de exposição destas a temperatura ambiente $\left(31,6^{\circ} \mathrm{C}\right)$. Huss (1993) afirmou que a refrigeração adequada dos produtos pesqueiros é essencial para controle do crescimento de microorganismos, inclusive dos patogênicos; a cadeia do frio não deve sofrer interrupção até o momento do consumo do produto.

Mendez (1974) comparando as BNVT e a TMA, como índices de qualidade, afirmou que o comportamento linear do BNVT é superior ao do TMA, indicando que ambos os índices são intercambiáveis, bastando apenas a determinação de BNVT para os fins visados. Faber (1963) observou que nem sempre os pesquisadores encontraram correlação suficiente entre os teores de bases nitrogenadas e a qualidade.

Waksman \& Lomanitz (1925) verificaram que, se pouco ou nenhum carboidratos estiver presente, o conteúdo de amônia ou de bases voláteis aumenta, apreciavelmente, durante a deterioração da carne, porém, se carboidratos estiverem presentes, a decomposição protéica, com formação de amônia, fica deprimida. Portanto, considerando os níveis de carboidratos encontrados nos mexilhões (1,31- 8,18g/100g), tem-se um caminho diferenciado na deterioração destes quando comparados a outros tipos de pescado marinho, indicando que padrões específicos para cada tipo de pescado devem ser definidos. Jay (1994) comentou que a composição química dos moluscos diferencia-se tanto dos teleósteos como dos crustáceos por conter em sua carne uma quantidade 
apreciável de compostos hidrocarbonados, principalmente na forma de glicogênio, por isso é esperado que, como parte integrante da alteração microbiana, tenham lugar atividades fermentativas.

\subsubsection{6 pH}

O potencial hidrogeniônico é o método de determinação de acidez de um produto alimentício, que pode fornecer um dado valioso sobre seu estado de conservação. O processo de decomposição altera quase sempre a concentração de íons hidrogênio de um alimento. A determinação do pH é importante no caso do pescado, pois este é de baixa acidez. (Brasil, 1980; Tavares et al., 1988). Os valores obtidos para o pH da carne dos mexilhões, nesta pesquisa, são apresentados na Tabela 4.

Tabela 4. pH da carne dos mexilhões in natura, mantidos sob refrigeração, de 24 a 192 horas após as coletas

\begin{tabular}{lcccccccc}
\hline & $24 \mathrm{~h}$ & $48 \mathrm{~h}$ & $72 \mathrm{~h}$ & $96 \mathrm{~h}$ & $120 \mathrm{~h}$ & $144 \mathrm{~h}$ & $168 \mathrm{~h}$ & $192 \mathrm{~h}$ \\
\hline \multicolumn{1}{c}{ JANEIRO } & & & & & & & & \\
Engenho & 6,2 & 6,4 & 6,4 & 6,5 & 6,7 & 6,9 & 6,9 & 7,2 \\
Barra Seca & 6,2 & 6,2 & 6,2 & 6,3 & 6,4 & 6,4 & 6,5 & 6,8 \\
Cedro & 6,1 & 6,4 & 6,4 & 6,5 & 6,6 & 6,8 & 6,7 & 7,0 \\
$\quad$ FEVEREIRO & & & & & & & & \\
Engenho & 6,5 & 6,3 & 6,3 & 6,5 & 6,6 & 6,8 & - & - \\
Barra Seca & 6,4 & 6,3 & 6,3 & 6,4 & 6,4 & 6,8 & 6,5 & 6,6 \\
Cedro & 6,4 & 6,3 & 6,3 & 6,4 & 6,4 & 6,4 & 6,5 & 6,5 \\
\multicolumn{1}{c}{ MARÇO } & & & & & & & & \\
Engenho & 6,1 & 6,1 & 6,4 & 6,5 & 6,5 & 6,5 & 6,5 & 6,4 \\
Cedro Seca & 6,3 & 6,1 & 6,4 & 6,4 & 6,5 & 6,6 & 6,7 & 6,5 \\
\hline
\end{tabular}


Os valores de $\mathrm{pH}$ encontrados neste trabalho variaram de 6,1 a 7,2, sendo as médias obtidas 24 horas após as coletas dos mexilhões dos cultivos do Engenho da Almada, Barra Seca e costão do Cedro; 6,29; 6,3 e 6,24, respectivamente. Considerando o pH próximo a neutralidade como ótimo para o crescimento de bactérias patogênicas, extremo cuidado deve ser tomado com este produto, desde a coleta até a mesa do consumidor.

O RIISPOA estabelece limite de $\mathrm{pH}$ para carne externa de peixes inferior a 6,8 e para interna, inferior a 6,5 (Brasil, 1980), não contemplando, especificamente, os moluscos. Tomando estes valores como referência, apenas as amostras de janeiro e fevereiro, provenientes da praia do Engenho, atingiram o pH de 6,8, no sexto dia após as coletas. As amostras provenientes da Barra Seca só atingiram pH 6,5, sete dias após as coletas de janeiro e fevereiro e, no mês de março, no quinto dia. Para o costão do Cedro, o pH de 6,5 foi atingido no quarto dia após as coletas dos meses de janeiro e março; enquanto, no mês de fevereiro, no sétimo dia de armazenamento. As amostras da praia do Engenho chegaram ao pH 6,5, sempre no quarto dia após as coletas.

Cruzando estes dados obtidos para o pH dos mexilhões com os obtidos para BNVT, não é possível estabelecer uma correlação; já os valores do pH e da TMA, 24 horas após as coletas, apresentaram uma correlação positiva. Segundo Nort, (1988), a medida do pH também não deve ser utilizada, individualmente, como índice de frescor, pois pode induzir a falsas avaliações. No entanto, seus valores devem geralmente acompanhar, paralelamente, análises químicas, microbiológicas e sensoriais. Muitos autores consideram que a determinação do pH não é um índice seguro do estado de frescor. Seu uso é geralmente restrito por variar de amostra para amostra e por ocorrerem flutuações durante o período de estocagem (Ogawa \& Maia, 1999; Borgstrom, 1965), o que também foi observado nesta pesquisa. Jay (1994) propôs a seguinte escala de pH como base para a determinação da qualidade microbiológica de ostras: $\mathrm{pH}$ 6,2 - 5,9 = boa; $\mathrm{pH}$ 5,8 = inadequada (off); $\mathrm{pH}$ 5,7 - 5,5 = inadequada; $\mathrm{pH}$ < 5,2 = deteriorada.

Ashie et al. (1996) explicam que os bivalves estocam energia em seus tecidos na forma de glicogênio e que o ácido lático produzido, como resultado da glicogenólise, 
reduz o pH. Liuzzo et al. (1975) também constataram decréscimo uniforme e significativo do $\mathrm{pH}$ da carne de ostras e do seu líquido intravalvar, com o período de estocagem em gelo, e associaram as ostras de boa qualidade e aceitáveis, organolépticamente, ao pH de até 6,49 e as que apresentavam sinais de deterioração ao $\mathrm{pH}$ de 6,32 a 6,21. No presente estudo constatou-se um aumento do $\mathrm{pH}$ da carne dos mexilhões com o período de estocagem e, até mesmo, algumas flutuações durante este período, diferente do apresentado pelos autores que trabalharam com ostras. Ogawa \& Maia (1999) comentam que os valores de ácido lático, em moluscos, são extremamente baixos devido a baixa atividade da L-lactatodesidrogenase. Na Tabela 4, é possível observar que o pH da carne dos mexilhões 24h após as coletas dos três cultivos, mostrou-se uniforme dentro do mesmo período, ou seja, considerando-se apenas o $\mathrm{pH}$, os mexilhões apresentaram qualidade similar dentro do mesmo período de coleta.

\subsubsection{TMA}

Quantitativamente, as maiores alterações químicas associadas à deterioração do pescado constituem-se na produção de bases nitrogenadas voláteis, particularmente a trimetilamina (TMA) e amônia $\left(\mathrm{NH}_{3}\right)$. A TMA é uma amina terciária formada pela redução do óxido de trimetilamina (OTMA). Este, que ocorre, amplamente, em todos os peixes marinhos, é associado a poucas espécies de água doce. Ainda, no caso de peixe de água salgada, os teores podem variar, largamente, de uma espécie para outra. Quando apenas a espécie é considerada, também podem ocorrer variações devidas, principalmente, a estações do ano e ao local de captura (Contreras Guzmán, 1988; Eiroa, 1980, Leitão, 1988).

Há espécies com alto teor de TMA como os cações e arraias, os quais atingem até $1.500 \mathrm{mg} \mathrm{N} / 100 \mathrm{~g}$. Na corvina (Micropogon sp.), pescada (Urophyas sp.), pargo (Sparus pagrus) e outros peixes de carne branca também se encontrou valores elevados entre 200 e 300mg N/ 100g e outras com valores mais reduzidos, como o atum (Thunnus sp.), que apresentam quantidades abaixo de 20mg N/ 100g (Contreras Guzmán, 1988). 
Estudos pioneiros, como o de Norris \& Bernoit (1945) alegavam ausência de OTMA em moluscos, mas nas últimas três décadas este tem sido encontrado em ostras, mexilhões, entre outros moluscos. Segundo Harada et al. (1971), somente dois bivalves, Pecten albicans e Vasticardium burchard e, um gastrópode, Tristichotrochus unicus, apresentaram quantidade significante de OTMA. Regenstein et al. (1982) afirmaram que este metabólito foi detectado em ostras Indianas e do Pacífico (Ostrea cullata e C.gigas), mas esteve ausente em ostras do Atlântico (C. virginica) e no mexilhão Mytilus edulis.

Na Tabela 5, é possível visualizar que a TMA apresentou valores médios próximos para os mexilhões provenientes das distintas áreas de cultivo estudadas, durante os meses de novembro de 2002 a março de 2003.

Tabela 5. TMA nos mexilhões in natura, 24 horas após as coletas

TMA

(mg N/ 100g) Novembro Dezembro Janeiro Fevereiro Março Desvio Padrão

\begin{tabular}{lllllll}
\hline Engenho & 1,4 & 1,1 & 1,3 & 5,6 & 4,1 & 2,04 \\
Barra seca & 1,7 & 1,1 & 1,3 & 7,7 & 3,6 & 2,77 \\
Costão do Cedro & 1,6 & 0,6 & 1,3 & 7,5 & 3,6 & 2,79 \\
\hline
\end{tabular}

Os valores de TMA encontrados nesta pesquisa variaram de 0,6 mg N/ 100g de pescado, no mês de dezembro, para a amostra do Costão do Cedro a 7,7mg N/ 100g, no mês de fevereiro, para a amostra da Barra Seca. Sendo as médias obtidas para o período de estudo, 3,7; 4,2 e 4,1 mg N/ 100g da amostra, provenientes das praias do Engenho da Almada, Barra Seca e costão do Cedro, respectivamente. Considerando o fator meses, obtiveram-se valores superiores no mês de fevereiro 5,6; 7,7 e $7.5 \mathrm{mg}$ N/ 100g e mínimos no mês de dezembro: 1,1; 1,1 e 0,6mg N/ 100g de mexilhão, propriamente para as praias do Engenho da Almada, Barra Seca e costão de Cedro.

Tomando-se como base a legislação vigente (Brasil, 1980), o pescado fresco deve apresentar níveis inferiores a 4mg N/ 100g; as legislações do Japão e da Austrália têm como limite 5mg N-TMA/ 100g (Jay, 1994). Segundo Harada et al. (1971), os 
bivalves contêm ao redor de 20mg N em $100 \mathrm{~g}$ e, em alguns gastrópodes, os níveis de TMA são maiores que os do OTMA. Outro fator que interfere nos níveis de TMA no pescado é a presença de algumas bactérias como a Escherichia coli, reconhecidamente redutora do OTMA a TMA.

Wong \& Gil (1987) encontraram uma relação essencialmente linear entre a contagem logarítmica bacteriana e o nível de TMA. Mendez (1974) afirma que as pesquisas não deixam dúvidas quanto a relação entre produção de TMA e contaminação microbiana que, por sua vez, é função do tipo de tratamento e armazenamento a que o pescado é submetido, refletindo, em última análise, a qualidade do produto. Segundo Amanajás (1985), a formação do TMA ocorre por ação dos microorganismos redutase positivo e por enzimas dos próprios tecidos, sendo a primeira via, a mais importante. Sendo a TMA um metabólito microbiano, esta não pode ser utilizada como índice de frescor e sim de deterioração (EU Commission, 2004).

A habilidade dos microorganismos em elaborar TMA é diminuída pela estocagem em gelo e pelo $\mathrm{pH}$ reduzido, o que limita seu uso como indicador de qualidade (Regenstein et al., 1982). No presente trabalho, a carne apresentou pH próximo a neutralidade propiciando a formação da TMA. No entanto, nenhum padrão pôde ser definido para a TMA, pois o conteúdo deste metabólito foi analisado somente 24 horas após as coletas, bem como, ocorreram grandes variações entre as amostras, mesmo quando os outros índices analisados apresentavam-se constantes, indicando desvantagem no uso deste composto como índice de qualidade para mexilhões. No mês de fevereiro todas as amostras analisadas apresentaram maior teor de TMA, menor de BNVT e pH mais elevado.

\subsection{Conclusões}

Os resultados obtidos neste estudo para o mexilhão Perna perna cultivado na região de Ubatuba, São Paulo - Brasil, permitem-nos estabelecer as seguintes conclusões: 
- Há variação dos constituintes químicos dos mexilhões em função da sazonalidade, bem como, do local de origem destes.

- O mexilhão é uma fonte protéica com baixo teor lipídico e calórico.

- Os mexilhões comercializados em Ubatuba apresentam bom rendimento, considerando como base o Índice de Condição Comercial proposto por Gomes et al. (1998).

- Seguindo os padrões do RIISPOA para pescado, quanto a BNVT e pH, os mexilhões apresentaram uma vida útil de 5 dias sob a temperatura de $10^{\circ} \mathrm{C}( \pm 1)$.

- Os mexilhões comercializados em Ubatuba, SP., até 24 horas após coleta, apresentaram-se com qualidade satisfatória para consumo quanto aos quesitos físico-químicos aqui analisados. Excetuando-se os capturados no mês de fevereiro, quando os valores de TMA encontrados superaram a legislação vigente.

- A mitilicultura praticada no litoral Norte paulista oferece ao consumidor local um produto de qualidade, garantindo a viabilidade desta atividade.

\subsection{Recomendações}

- Novos estudos precisam ser realizados para definição de padrões de qualidade adequados aos moluscos, estes ainda inexistentes na legislação brasileira. 


\subsection{Referências bibliográficas}

ACKMAN, R.G. Composición y valor nutritivo de los lípidios del pescado y del marisco. In: RUITER, A. El pescado y los productos derivados de la pesca: composición, propriedades nutritivas y estabilidad. Zaragoza: Acribia, 1999. cap.4, p.81-121.

AMANAJÁS, C.C. Determinação dos compostos básicos totais de pescado e seu potencial para avaliação do frescor. Campinas, 1985. 78p. Dissertação (Mestrado) Faculdade de Engenharia de Alimentos e Agrícola, Universidade Estadual de Campinas.

ANTANOCOPOULOS, N.; VINCKE, W. Determination of volatile basic nitrogen in fish: a third colaborative study by the West European Fish Technologists Association (WEFTA). Zeitschrift Lebensm Unters Forsh, v.189, p.309, 1989.

ANTONIOLLI, M.A. Vida útil do mexilhão Perna perna (L.) processado e mantido sob refrigeração. Florianópolis, 1999. 99p. Dissertação (Mestrado) - Centro de Ciências Agrárias, Ciência e Tecnologia dos Alimentos, Universidade Federal de Santa Catarina.

ASHIE, I.N.A.; SMITH, J.P.; SIMPSON, B.K. Spoilage and shelf-life extension of fresh fish and shellfish. Critical Reviews in Food Science and Nutrition, v.36, n.1/ 2, p.81-121, 1996.

BASE de dados de nutrientes do USDA SR14: mexilhão, azul, cozido. http://www.unifesp.br/dis/servicos/nutri/nutri.php?id=4111 (24 Apr. 2002) 
BORGSTROM, G. Physicochemical methods. In: BORGSTROM, G. (Ed.). Fish as food. New York: Academic Press, 1965. v.4, cap.2, p.71-126.

BORGSTROM, G. Shellfish protein: nutritive aspects. In: BORGSTROM, G. (Ed.). Fish as food. New York: Academic Press, 1962. v.2, p.115-148.

BRASIL. Ministério da Agricultura, Pecuária e Abastecimento. Regulamento da Inspeção Industrial e Sanitária de Produtos de Origem Animal - RIISPOA. Brasília, 1980. 165p.

BRASIL. Ministério da Agricultura, Pecuária e Abastecimento. Secretaria Nacional de Defesa Agropecuária. Laboratório Nacional de Referência Animal. Métodos analíticos oficiais físico-químicos para controle de pescados e seus derivados. Brasília, 1981. cap.5, p.1-3: Métodos quantitativos.

BOTTA, J.R. Freshness quality of seafoods: a review. In: SHAHIDI, F.; BOTTA, J.R. (Ed.). Seafoods. London: Chapman \& Hall, 1994. cap.9, p.140-167.

CONTRERAS GUZMÁN, E.S. Bioquímica de pescados e derivados. Jaboticabal: FUNEP, 1994. 409p.

CONTRERAS GUZMÁN, E.S. Métodos químicos para análise de pescado. In: SEMINÁRIO SOBRE CONTROLE DE QUALIDADE NA INDÚSTRIA DE PESCADO, Santos, 1988. Anais. São Paulo: Instituto de Pesca, 1988. p.196-209.

DAVIS, H.K. Calidad y alteración del pescado crudo. In: RUITER, A. El pescado y los productos derivados de la pesca: composición, propriedades nutritivas y estabilidad. Zaragoza: Acribia, 1999. cap.7, p.225-256. 
DORÉ, I. Fish and shellfish quality assessment: a guide for retailers and restauranteurs. New York: Van Nostrand Reinhold, 1941. 44p.

EHIRA, S.; UCHIYAMA, H. Determination of fish freshness using the $k$ value and comments on some other biochemical changes in relation to freshness. In: KRAMER, D.E.; LISTON, J. (Ed.). Seafood quality determination. New York: Elsevier, 1987. p.185-207.

EIROA, M.N.U. Aspectos microbiológicos relacionados à conservação e ao consumo de pescado. Boletim da Sociedade Brasileira de Ciência e Tecnologia de Alimentos, n.54, p.9-37, 1980.

EU COMMISSION. Freshness, quality and safety in seafoods. http://www.seafood.ucdavis.edu/pubs/qualitysafety.doc (16 Jan. 2004)

FABER, L. Quality evaluation studies of fish and shellfish from certain northern european waters. Food Technology, v.17, n.4, p.110-114, 1963.

GELLI, V.C. Aproveitamento de mexilhões: aspectos gerais Mollusca-Bivalvia. Fortaleza, 1992. 64p. Monografia (Especialização) - Universidade Federal do Ceará.

GOMES, R.O.; MARENZI, A.W.C.; MANZONI, G.C. Utilização econômica do índice de condição do mexilhão Perna perna (L., 1758), no parque de mitilicultura na enseada de Armação do Itapocoroy, (26³7’S-48³6’W) Penha, SC, Brasil. In: SIMPÓSIO BRASILEIRO DE AQUICULTURA, 10., Recife, 1998. Resumos. Recife: Universidade Federal de Pernambuco, 1998. p.119.

GRAM, L.; HUSS, H.H. Microbiological spoilage of fish and fish products. International Journal of Food Microbiology, v.33, p.121-137, 1996. 
HAARD, N.F. Valor nutritivo y composición de las proteínas y otros compuestos nitrogenados del pescado. In: RUITER, A. (Ed.). El pescado y los productos derivados de la pesca: composición, propiedades nutritivas y estabilidad. Zaragoza: Acribia, 1999. cap.3, p.81-121.

HARADA, K.; YAMAMOTO, Y.; YAMADA, K. Distribuition of trimethylamine oxide in fishes and other aquatic animals III - Gastropodan mollusca. Suisan Daigakko Kenkyu Hokoku, v.19, p.105-114, 1971.

HEBARD, C.E.; FICK, G.J.; MARTIN, R.E. Occurrence and significance of trimethylamine oxide and its derivatives in fish and shellfish. In: MARTIN, R.E.; FLICK, G.J.; HEBERD, C.E.; WARD, D.R. (Ed.). Chemistry \& biochemistry of marine food products. Westport: The Avi publishing company, 1982. p.149-304.

HILTZ, D.F.; DYER, W.J.; NOWLAN, S. et al. Variation of biochemical quality indices by biological and technological factors. In: KREUZER, R. Fish inspection and quality control. London: Fishing News, 1971. p.191-195.

HUIS IN'T VELD, J.H.J. Microbial and biochemical spoilage of foods: an overview. International Journal of Food Microbiology, v.33, p.1-18, 1996.

HUNGERFORD, J.M. Fish and other marine products. In: ASSOCIATION OF OFFICIAL AGRICULTURAL CHEMISTS (A.O.A.C.). Official methods of analysis. Washington, 1995. cap.35, p.1-30.

HUSS, H.H. Assurance of seafood quality. Rome: FAO, 1993. 169p. (FAO Fisheries technical paper, 334)

JAY, J.M. Microbiología moderna de los alimentos. 3.ed. Zaragoza: Acribia, 1994. 804p. 
LATHAM, M.C. Nutrición humana en el mundo desarrollo. Roma: FAO, 2002. cap.9, p.101: Macronutrientes: carboidratos, grasas, y proteínas.

LEITÃO, M.F.F. Microbiologia e deterioração do pescado fresco e refrigerado de origem fluvial ou marinha. In: SEMINÁRIO SOBRE CONTROLE DE QUALIDADE NA INDÚSTRIA DE PESCADO, Santos, 1988. Anais. São Paulo: Instituto de Pesca, 1988. p.40-58.

LIUZZO, J.A.; LAGARDE, S.C.; GRODNER, R.M.; NOVAK, A.F. A total reducing substance test for ascertaining oyster quality. Journal of Food Science, v.40, p.125128, 1975.

LUDORF, W.; MEYER, V. El pescado y sus productos de la pesca. 2.ed. Zaragoza: Acríbia, 1978. p.32-55.

MAGALHÃES, A.R.M. Teor de proteína do mexilhão Perna perna (Linné, 1957) (Molusca - Bivalvia) em função do ciclo sexual. São Paulo, $1985.117 p$. Dissertação (Mestrado) - Instituto de Biociências, Universidade de São Paulo.

MARQUES, H.L.A. Criação comercial de mexilhão: métodos e etapas, a produção e seus custos, a colheita e a comercialização. São Paulo: Nobel, 1998. 111p.

MARQUES, H.L.A; PEREIRA, R.L. Levantamento e dimensionamento preliminares das áreas mais favoráveis para a prática da mitilicultura no Litoral do município de Ubatuba, Estado de São Paulo ( $23^{0}{ }^{25}{ }^{\prime} \mathrm{S}, 045^{0} 04^{\prime}$ ' W). São Paulo, 1989. 10p. (Boletim Técnico do Instituto de Pesca, 13)

MENDEZ, M.H.M. Evolução das bases voláteis totais e da trimetilamina em pescado e o seu uso como indicador de qualidade. São Paulo, 1974. 63p. Dissertação (Mestrado) - Faculdade de Ciências Farmacêuticas, Universidade de São Paulo. 
MORGA, A.A. Avaliação do índice de frescor da pescada foguete (Macrodon ancylodon) conservada em gelo. Campinas, 1975. 80p. Dissertação (Mestrado) Faculdade de Tecnologia de Alimentos, Universidade Estadual de Campinas.

NORT, E. Importância do controle físico na qualidade do pescado. In: SEMINÁRIO SOBRE CONTROLE DE QUALIDADE NA INDÚSTRIA DE PESCADO, Santos, 1988. Anais. São Paulo: Instituto de Pesca, 1988. p.135-144.

NORRIS, E.R.; BERNOIT, G.J. Studies on TMA-O I: distribuition of TMA-O in some marine animals. Journal of Biological Chemistry, v.158, p.435-438, 1945.

OGAWA, M.; MAIA, E.L. Manual da pesca. São Paulo: Varela, 1999. 430p.

REGENSTEIN, J.M.; SCHLOSSER, M.A.; SAMSON, A.; FEY, M. Chemical changes of trimethylamine oxide during fresh and frozen storage of fish. In: MARTIN, R.E.; FLICK, G.J.; HEBERD, C.E.; WARD, D.R. (Ed.). Chemistry \& biochesmitry of marine food products. Westport: Avi Publishing, 1982. p.137-147.

RODRÍGUEZ-JÉREZ, J.J.; HERNÁNDEZ-HERRERO, M.M.; ROIG-SAGUÉS, A.X. New methods to determine fish freshness in research and industry. http://ressources.cibeam.org/om/pdf/c51/00600292.pdf (15 Mar. 2004)

SCHRAMM, M.A. Caracterização e aproveitamento de mexilhões Perna perna (Linné, 1758). Rio Grande, 1993. 54p. (Graduação) - Faculdade de Oceanologia, Universidade do Rio Grande.

SPINELLI, M.R.; EKLUND, M.; MIYAUCHI, D. Mensurement of hypoxanthine in fish as a method of assessing freshness. Journal of Food Science, v.19, p.710-714, 1964. 
TAVARES, M.; AMARAL MELO, M.R.P.; CAMPOS, N.C. et al. Proximate composition and caloric value of the mussel Perna perna, cultivado em Ubatuba, estado de São Paulo, Brasil. Food Chemistry, v.62, n.4, p.473-475, 1998.

TAVARES, M.; SABRIA, A.; BACETTI, L.B. et al. Métodos sensoriais, físicos e químicos para análise de pescado. In: SEMINÁRIO SOBRE CONTROLE DE QUALIDADE NA INDÚSTRIA DE PESCADO, Santos, 1988. Anais. São Paulo: Instituto de Pesca, 1988. p.117-134.

WAKSMAN, S.A.; LOMANITZ, S. Contribution to the chemistry of decomposition of proteins and amino acids by various groups of microorganisms. Journal of Agricultural Research, v.30, n.3, p.263-281, 1925.

WONG, K.; GILL, T.A. Enzymatic determination of trimethylamine and its relationship to fish quality. Journal of Food Science, v.52, n.1, p.1-3, 1987. 


\section{QUALIDADE MICROBIOLÓGICA DE MEXILHÕES Perna perna CULTIVADOS E COMERCIALIZADOS NO LITORAL NORTE DE SÃO PAULO}

\subsection{Resumo}

A deterioração do pescado é muito rápida. Sendo um alimento altamente nutritivo, com $\mathrm{pH}$ próximo a neutralidade e elevado teor de umidade, o pescado, conseqüentemente, permite o crescimento de uma gama de microorganismos. Esta pesquisa objetivou caracterizar a qualidade microbiológica dos mexilhões Perna perna cultivados e comercializados em três distintas áreas do município de Ubatuba, SP, a saber, praia do Engenho da Almada, praia da Barra Seca e costão do Cedro, segundo os padrões microbiológicos vigentes na legislação. Foram determinados, no período de novembro de 2002 a março de 2003, na carne dos mexilhões e na respectiva água de cultivo, coliformes totais e fecais, Staphylococcus aureus e Salmonella sp. As amostras apresentaram qualidade satisfatória e condizente com os padrões da legislação vigente, para pescado, durante a maior parte do período de estudo, excetuando-se em março, quando os mexilhões provenientes da Barra Seca se apresentaram inadequados para o consumo humano direto, pois acusaram resultado positivo para Samonella. As maiores contagens para coliformes totais ocorreram em mexilhões provenientes de áreas de cultivo densamente povoadas e que recebiam efluentes sem tratamento prévio (Barra Seca), excetuando-se em novembro, quando os mexilhões do costão obtiveram maiores contagens para estes microrganismos $\left(1,3 \times 10^{3} \mathrm{NMP} / \mathrm{g}\right)$. A presença de Salmonella na 
carne dos mexilhões coincidiu com a transposição do limite para coliformes fecais em 4,5\% das amostras de água do respectivo cultivo.

\subsection{Summary}

The seafood spoilage is very fast. This food is highly nutritious; it has a neutral $\mathrm{pH}$ and high moisture content. Therefore, permit growth of a wide range of microorganisms. This research aimed to characterize the microbiological quality of the Perna perna cultivated and commercialized mussels in three different points of Ubatuba’s city, SP.; Engenho da Almada and Barra Seca beach’s and Cedro’s coast, according to standards of the effective fish legislation. The total and fecal coliforms, Staphylococcus aureus and Salmonella counts in the mussel's meat and in their cultivation waters were determined, during November, 2002 to March, 2003. Most of the samples of mussels came inside of the standard of the effective fish legislation; only the Barra Seca's mussels, in March, weren’t appropriate for the direct consumption, when they accused positive result to Salmonella $s p$. The largest total coliforms counts happened in mussels cultivated in densely populated areas and that received sewage without previous treatment (Barra Seca), except in November, when the mussels from Cedro's coast have largest counts of these microorganisms $\left(1,3 \times 10^{3} \mathrm{NMP} / \mathrm{g}\right)$. The 4,5\% of the samples had positive result to Salmonella $s p$. from mussels meat coincided with the fecal coliforms counts from respective cultivation water above of the standard of the legislation.

\subsection{Introdução}

A colimetria e classificação das águas provenientes de áreas onde são coletados ou cultivados bivalves constituem, sempre, um subsídio científico útil para as autoridades envolvidas na fiscalização e controle da qualidade dos alimentos, uma vez 
que a presença desses microrganismos indica as condições sanitárias desses produtos (Lira et al., 2000; Estados Unidos, 1992). No município de Ubatuba, a Companhia de Tecnologia de Saneamento Ambiental (CETESB) realiza o monitoramento de 23 praias; a maioria apresentou-se em boas condições de balneabilidade durante o ano de 2001 (CETESB, 2002).

Na Resolução do Conselho Nacional do Meio Ambiente (CONAMA) n ${ }^{0}$ 20, de 18 de junho de 1986, Art.1 ${ }^{\circ}$, quanto a classificação das águas, segundo seus usos preponderantes, a qualidade destas, para banho (balneabilidade), encontra-se na mesma categoria que as águas de cultivo (Classe V), no entanto, com limites para bactérias coliformes fecais (CF) diferenciados. Sendo que, para as águas de cultivo, não deve ser excedida uma população média de 14 CF/ 100mL, com não mais de 10\% das amostras excedendo 43 CF/ 100mL (Brasil, 1986; Cook, 1991).

Os coliformes fecais são indicadores específicos e apresentam elevada correlação positiva com a contaminação fecal por animais de sangue quente e, a alimentação por filtração, efetuada pelos mexilhões, concentra os microorganismos presentes no ambiente marinho. Várias críticas e algumas desvantagens são apontadas quanto ao uso dos coliformes como indicadores de poluição fecal, em ambientes hídricos, devido a sua baixa tolerância à toxicidade da água do mar, bem como, ao procedimento de cloração em relação a alguns patógenos resistentes (Pádua, 2003).

A enumeração de coliformes totais em água é menos representativa como indicação de contaminação fecal que a enumeração de coliformes termotolerantes ou Escherichia coli. No entanto, sua enumeração é utilizada em indústrias alimentícias, indicando poluição pré-sanitização, contaminação pós-sanitização ou pós-processo, evidenciando práticas de higiene e sanitização aquém dos padrões requeridos para o processamento de alimentos (Pádua, 2003). No Brasil, a Agência Nacional da Vigilância Sanitária (ANVISA), órgão que regulamenta os padrões microbiológicos em alimentos, através da resolução RDC $\mathrm{n}^{\circ} 12$, de 2 de janeiro de 2001, preconiza que os moluscos bivalves in natura, resfriados ou congelados, e que não serão consumidos crus, apresentem-se livres de Salmonella sp. em $25 \mathrm{~g}$ e, limita em $10^{3} \mathrm{NMP}$, a contagem de Staphylococcus coagulase positiva/ g do pescado (Brasil, 2001). 
Segundo Huss (1992), a inclusão da contagem para Staphylococcus aureus nos padrões microbiológicos para produtos crus, com grande biota associada, é de pouco valor, visto que o crescimento deste microorganismo é limitado pela competição com os outros microorganismos presentes no produto cru. Sendo esta contagem recomendada apenas para produtos cozidos.

A contagem do número de células viáveis é complexa e consome tempo, não sendo um método prático para estimação do frescor. No entanto, a qualidade microbiológica dos alimentos marinhos é um fator chave para a comercialização e segurança para o consumo.

\subsection{Material e métodos}

\subsubsection{Escolha dos pontos de coleta}

As áreas propícias para a implantação da mitilicultura no município de Ubatuba, Estado de São Paulo, encontram-se geo-referenciadas por meio de posicionamento por satélites (Global Position System -GPS), totalizando 30 pontos (Gelli \& Carneiro, 2003). Para a realização desta pesquisa foram escolhidos três pontos onde a atividade da mitilucultura já havia sido implantada e que se caracterizavam por serem bem distintos (Marques \& Pereira, 1989; Gelli \& Carneiro, 2003). A eleição de três diferentes pontos para as coletas foi realizada em reunião no Instituto de Pesca / Agência Paulista de Tecnologia dos Agronegócios (Apta), Núcleo de Pesquisa do Litoral Norte, com profissionais da área de oceanografia e de recursos pesqueiros.

Os pontos de coleta estudados encontram-se localizados nas praias da Barra Seca

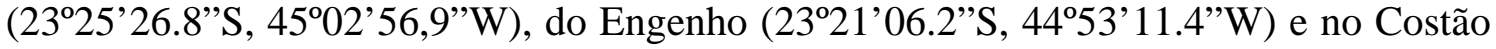
do Cedro (233' 45.5’”S, 4509’32.9”W). Todos classificados como área de ocupação primária, ou seja, que apresentam condições favoráveis ao cultivo de mexilhões (Marques \& Pereira, 1989). 


\subsubsection{Caracterização dos pontos de coleta}

A praia do Engenho, no povoado da Almada, localiza-se a $44 \mathrm{Km}$ do centro de Ubatuba, sentido Norte e próxima a área de preservação ambiental, legalmente instituída, Núcleo Picinguaba. O cultivo, em sistema long lines, apresenta redes com 1,5m de comprimento, em polietileno, a 80 m de distância da costa mais próxima; a região possui fossa asséptica para os efluentes domésticos. A praia da Barra Seca localiza-se em região densamente povoada, separada da praia do Perequê-açú pelo rio Indaiá. O cultivo abrange uma área de $2.000 \mathrm{~m}^{2}$, tem 5 long lines com tamanho aproximado de 1,5m de comprimento, a uma distância aproximada de 1,5 Km da costa e 1,6 Km do Rio Indaiá. O costão do Cedro localiza-se na região central de Ubatuba, aproximadamente, a $4 \mathrm{Km}$ da principal saída de efluentes orgânicos (esgoto), que passam por tratamento através de cloração anteriormente à sua devolução ao ambiente. Em região de mar aberto e protegido ao Sul, apresenta 700 redes plantadas em cordas de 1,8 a 2,5m de comprimento, em local onde a profundidade varia de 4,5 a $6 \mathrm{~m}$.

\subsubsection{Matéria-prima analisada}

Cerca de $10 \mathrm{Kg}$ de mexilhões da espécie Perna perna foram coletados, mensalmente, de cada um dos pontos de cultivo, no período de novembro de 2002 a março de 2003, totalizando 5 coletas. Estes, foram submetidos ao processo de desdobre, no qual o próprio produtor faz a retirada dos cachos, separando-os da fauna acompanhante, retirando cracas e parasitas. Posteriormente, foram lavados com água do mar, no caso da praia do Engenho e com água tratada pela SABESP, nos outros dois pontos (Barra Seca e costão do Cedro), efetuando-se assim, a limpeza superficial das valvas. Após este processo, os mexilhões foram acondicionados em sacos de ráfia e transportados em vasilhames isotérmicos contendo gelo comercial filtrado, na proporção de 3:1 (mexilhão:gelo), sem contato direto entre estes, evitando-se assim a morte dos bivalves. Chegando ao setor de Processamento de Alimentos do Departamento de 
Agroindústria, Alimentos e Nutrição, as amostras foram armazenadas a granel, sob refrigeração a $10^{\circ} \mathrm{C} \pm 1^{\circ} \mathrm{C}$.

A água de cultivo destes bivalves também foi estudada, sendo a coleta efetuada seguindo recomendações da Companhia de Tecnologia de Saneamento Ambiental (CETESB,1988). Foram utilizados frascos de vidro neutro de borossilicato com capacidade para 1L, os quais foram previamente envoltos em papel pardo e esterilizados por 2h, em estufa Fanem, modelo 315 SE, a temperatura de $170-180^{\circ} \mathrm{C}$.

Os frascos foram mergulhados, em contra corrente, paralelamente, ao movimento da água, cerca de $30 \mathrm{~cm}$ abaixo da superfície da água, evitando-se a introdução de contaminantes superficiais; os frascos foram inclinados, lentamente, para cima, a fim de permitir a saída do ar e conseqüente enchimento do mesmo. Após a retirada dos frascos da água, desprezou-se uma pequena porção da amostra, deixando espaço suficiente à homogeneização da amostra para análise. As amostras foram devidamente identificadas e transportadas em caixas isotérmicas contendo gelo, como ilustra a Figura 6.
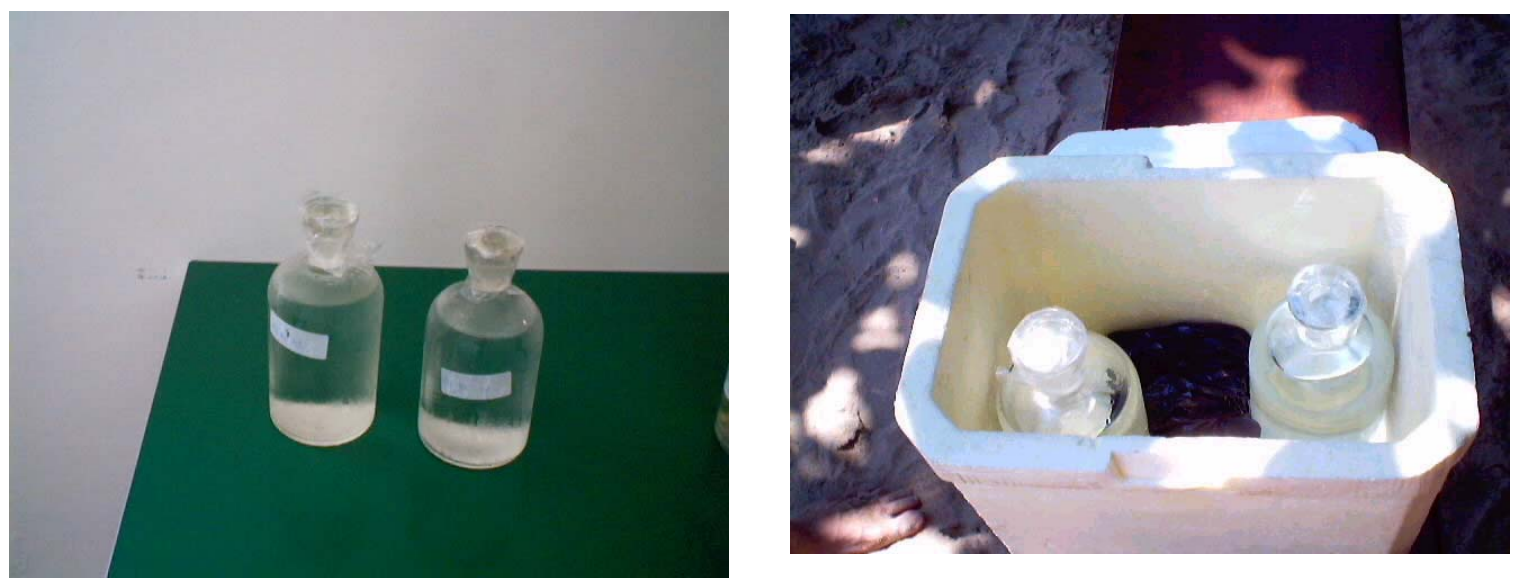

Figura 6 - Identificação e transporte das amostras de água

\subsubsection{Análises microbiológicas}

As análises microbiológicas dos mexilhões in natura e da água de cultivo destes foram efetuadas no laboratório de Microbiologia, do setor de Biologia do Laboratório Regional de Apoio Animal do Ministério da Agricultura, Pecuária e Abastecimento 
(LARA/MAPA) e foram realizadas, mensalmente, no dia posterior ao da coleta, para cada ponto de cultivo (Engenho, Barra Seca e costão do Cedro).

\subsubsection{Preparo das amostras de mexilhões}

As amostras foram manipuladas em câmara de fluxo laminar, na qual, as valvas, previamente a sua abertura, foram higienizadas com algodão embebido em solução de ácido peracético 0,02\%, evitando-se assim, contaminações durante a abertura das mesmas. A carne, mais o líquido intravalvar, foram retirados das valvas e depositados em becker de 1L, até atingir o peso de 250g. A amostra foi homogeneizada em “stomacher” Seward até apresentar aspecto homogêneo. Para todas as análises, pesou-se 25g da amostra homogeneizada, adicionou-se $225 \mathrm{~mL}$ de solução salina peptonada a $0,1 \%$, sendo esta mistura homogeneizada novamente em "stomacher" por 60 seg. A partir da diluição $10^{-1}$ foram feitas as diluições decimais subseqüentes, tantas quanto o necessário para as contagens. Todas as análises foram realizadas em duplicata.

\subsubsection{Microrganismos analisados nas amostras de mexilhões}

\subsection{Coliformes totais (CT) e coliformes fecais (CF)}

Para a análise do número mais provável de CT e CF, foi utilizada a técnica dos tubos múltiplos, série de 3 tubos. Para a prova presuntiva, preparou-se diluições de $10^{-1} \mathrm{a}$ $10^{-4}$ e semeou-se alíquotas de $1 \mathrm{~mL}$ em uma série de 3 tubos contendo Caldo Lauril Sulfato de Sódio. Incubaram-se os tubos a $36^{\circ} \mathrm{C} \pm 1^{\circ} \mathrm{C}$ por 48 horas. A positividade foi indicada pela formação de gás nos tubos de Duhram. Para a confirmação de CT, repicou-se os tubos positivos de Caldo Lauril Sulfato de Sódio para tubos de CVBB (Caldo Verde Brilhante Bile) 2\% lactose, que foram incubados a $36^{\circ} \mathrm{C} \pm 1^{\circ} \mathrm{C}$ por $48 \mathrm{~h}$. Para a prova confirmatória de CF, repicou-se os tubos positivos de Caldo Lauril Sulfato de Sódio para tubos de caldo EC, incubando-os a $45^{\circ} \mathrm{C} \pm 0,2^{\circ} \mathrm{C}$, por $48 \mathrm{~h}$, em banhomaria com agitação. A presença de gás indica positividade do tubo para a presença de 
CF. Através da combinação do número de tubos positivos, em cada série de diluição, nos testes para CT e CF e consultando-se a Tabela de Número Mais Provável -NMP, obteve-se NMP de CF por grama ou $\mathrm{mL}$ da amostra (American Public Health Association -APHA, 1998; Hitchins et al., 2001).

\subsection{Contagem de Staphylococcus aureus}

Foram preparadas as diluições de $10^{-1}$ a $10^{-3}$ que foram semeadas em alíquotas de 0,1 mL sobre a superfície seca de BPA (Baird-Parker Ágar), adicionando-se gema de ovo e telurito. Efetuou-se o espalhamento utilizando a técnica de superfície. Foram utilizadas, duas diluições decimais ou duplicata da mesma diluição. Nos casos em que se necessitou de resultados menores do que $100 \mathrm{UFC} / \mathrm{g}$ ou $\mathrm{mL}$, distribuiu-se $1 \mathrm{~mL}$ da

diluição $10^{-1}$ em 3 placas $(0,4 \mathrm{~mL}, 0,3 \mathrm{~mL}$ e $0,3 \mathrm{~mL})$. As placas foram incubadas invertidas, a $36^{\circ} \mathrm{C} \pm 1^{\circ} \mathrm{C}$ por 30 a $48 \mathrm{~h}$. Selecionou-se placas que continham entre 20 e 200 colônias típicas (negras brilhantes com anel opaco, rodeadas por um halo claro transparente) ou atípicas (acinzentadas ou negras brilhantes, sem halo ou com apenas um dos halos). Registrou-se a contagem de colônias típicas e atípicas. Selecionou-se 3 a 5 colônias de cada tipo que foram semeadas em tubos contendo caldo BHI. Incubaram-se os tubos a $36^{\circ} \mathrm{C} \pm 1^{\circ} \mathrm{C}$, por $24 \mathrm{~h}$. Foram realizadas as seguintes provas confirmatórias: coloração de Gram, coagulase, termonuclease e catalase. Para a quantificação de $S$. aureus presentes por grama ou $\mathrm{mL}$ da amostra, considerou-se a diluição da placa submetida à contagem (Lancette \& Tatini, 2001).

\subsection{Pesquisa de Salmonella sp.}

Para a determinação de Salmonella sp., após a permanência da amostra de $25 \mathrm{~g}$ em temperatura ambiente, por $1 \mathrm{~h}$, incubou-se a $36^{\circ} \mathrm{C} \pm 1^{\circ} \mathrm{C}$, por 16 a $20 \mathrm{~h}$, finalizando a prova de pré-enriquecimento. Para enriquecimento seletivo, inocubou-se caldo de préenriquecimento em alíquota de 0,1 mL em caldo Rappaport Vassiliadis e de alíquotas de $1 \mathrm{~mL}$ em caldos selenito cistina e caldo tetrationato. A partir deste cultivo, incubou-se os 
tubos a $41^{\circ} \mathrm{C} \pm 0,5^{\circ} \mathrm{C}$, em banho-maria com agitação, por 24 a $30 \mathrm{~h}$. O caldo de enriquecimento seletivo foi semeado por estrias em superfície em placas ágar Rambach, MLCBA (Manitol Lysine Crystal Violet Brilhant Green Agar), BPLSA (Brilhant Green Phenol Red Lactose Sucrose Agar) e XLDA (Xylose Lisine Agar), para obtenção de colônias isoladas. Incubou-se as placas invertidas a $36^{\circ} \mathrm{C} \pm 1^{\circ} \mathrm{C}$ por 18 a 24 horas.

Para as provas preliminares, inoculou-se cada colônia suspeita em ágar TSI (Triple Sugar Iron Agar) e LIA (Lysine Iron Agar), através de picada profunda e estriamento. Paralelamente, inoculou-se em ágar BHI (Brain Heart Infusion) inclinado para verificação de pureza e manutenção da cepa. Incubou-se a $36^{\circ} \mathrm{C} \pm 1^{\circ} \mathrm{C}$ por 18 a $24 \mathrm{~h}$. Para provas complementares, partiu-se de colônias crescidas em ágar BHI, no qual foram inoculadas as colônias com as respostas esperadas de Salmonella sp. em ágar TSI e LIA, e em meios para: produção de urease; utilização de malonato; descarboxilação da lisina; utilização de citrato; desaminação da fenilalanina; meio SIM; fermentação da lactose; fermentação do manitol; reação de VM-VP - Voges Proskauer. Para provas confirmatórias, as colônias suspeitas de Salmonella $s p$ foram submetidas às seguintes provas: reação de oxidase; reação de PYRase; prova da catalase e sorologia. O resultado foi expresso como, presença ou ausência, em 25 g ou mL da amostra (Andrews et al., 1992; Bennett et al., 1999).

\subsubsection{Preparo das amostras de água}

As amostras de água foram homogeneizadas através de agitação no próprio frasco de coleta e, posteriormente, retirou-se alíquotas para cada uma das análises que se seguiram em triplicatas, nas quais, inoculou-se $0,1 \mathrm{~mL}$ diretamente da amostra $\left(10^{\circ}\right)$, o que correspondeu a diluição $10^{-1}$.

\subsubsection{Microrganismos analisados nas amostras de água}




\subsection{Coliformes totais (CT) e coliformes fecais (CF)}

Para a prova presuntiva, inoculou-se $10 \mathrm{~mL}$ da amostra em uma série de 3 tubos contendo Caldo Lauril Sulfato de Sódio em concentração dupla. Inoculou-se volumes de $1 \mathrm{~mL}$ da amostra, em uma série de 3 tubos, contendo Caldo Lauril Sulfato de Sódio em concentração simples, e volumes de $1 \mathrm{~mL}$ da diluição $10^{-1}$ em outra série de 3 tubos contendo o mesmo meio. Incubaram-se os tubos a $36^{\circ} \mathrm{C} \pm 1^{\circ} \mathrm{C}$, por 48 horas. Foram considerados positivos os tubos contendo gás. O procedimento restante segue conforme o item 4.4.4.2.1.

\subsection{Staphylococcus aureus}

Para esta análise foram utilizadas as diluições $10^{-1}$ e $10^{-2}$, sendo que o procedimento restante seguiu da mesma forma descrita no item 4.4.4.2.2

\subsection{Pesquisa de Salmonella sp.}

Idem ao item 4.4.4.2.3, utilizando-se $25 \mathrm{~mL}$ de amostra de água.

\subsection{Resultados e discussão}

\subsubsection{Mexilhões}

\subsubsection{Coliformes totais e fecais}

A contagem dos coliformes totais (CT) corresponde ao total dos microorganismos Gram-negativos da família das Enterobacteriáceas encontrados em uma amostra (Pádua, 2003). Apesar da legislação brasileira não possuir padrão para este tipo de produto, no que se refere a CT, tais análises dão informações sobre as condições 
de higiene do produto. Os resultados médios obtidos para esse grupo de microrganismos, apresentaram variação de $2,5 \times 10^{1}$ a $2,3 \times 10^{3} \mathrm{NMP} / \mathrm{g}$ de pescado, sendo a menor contagem referente as amostras do costão do Cedro, no mês de março e, a maior, da Barra Seca, em janeiro. Os resultados em NMP de coliformes podem ser visualizados na Tabela 6.

Tabela 6. Coliformes totais e fecais (NMP/g), 24 horas após as coletas

\begin{tabular}{|c|c|c|c|c|c|}
\hline \multirow[t]{2}{*}{ Meses } & \multirow[t]{2}{*}{ Local } & \multicolumn{2}{|c|}{ Coliformes Totais } & \multicolumn{2}{|c|}{ Coliformes Fecais } \\
\hline & & (mexilhões) & (água) & (mexilhões) & (água) \\
\hline \multirow[t]{3}{*}{ Novembro } & Engenho & $7,2 \times 10^{2}$ & $<3$ & 3,1 & $<3$ \\
\hline & Barra Seca & $6,7 \times 10^{2}$ & $<3$ & $3,0 \times 10^{1}$ & $<3$ \\
\hline & Costão & $1,3 \times 10^{3}$ & $<3$ & 7,0 & $<3$ \\
\hline \multirow[t]{3}{*}{ Dezembro } & Engenho & $4,3 \times 10^{1}$ & $<3$ & $2,3 \times 10^{1}$ & $<3$ \\
\hline & Barra Seca & $4,3 \times 10^{2}$ & $<3$ & 9,1 & $<3$ \\
\hline & Costão & $4,3 \times 10^{1}$ & $<3$ & 9,1 & $<3$ \\
\hline \multirow[t]{3}{*}{ Janeiro } & Engenho & $1,7 \times 10^{3}$ & 5,4 & $1,6 \times 10^{1}$ & $<3$ \\
\hline & Barra Seca & $2,3 \times 10^{3}$ & 3,4 & $1,6 \times 10^{1}$ & 3,1 \\
\hline & Costão & $6,8 \times 10^{2}$ & 5,0 & 3,2 & 2,9 \\
\hline \multirow[t]{3}{*}{ Fevereiro } & Engenho & $6,8 \times 10^{1}$ & $<3$ & 3,3 & $<3$ \\
\hline & Barra Seca & $1,4 \times 10^{3}$ & 3,4 & $9,3 \times 10^{1}$ & 3,1 \\
\hline & Costão & $3,3 \times 10^{1}$ & 3,4 & $1,6 \times 10^{1}$ & 3,4 \\
\hline \multirow[t]{3}{*}{ Março } & Engenho & $3,3 \times 10^{2}$ & $1 \times 10^{1}$ & $1,6 \times 10^{1}$ & 3,4 \\
\hline & Barra Seca* & $1,4 \times 10^{3}$ & $3,6 \times 10^{2}$ & $3,2 \times 10^{2}$ & $5,7 \times 10^{1}$ \\
\hline & Costão & $2,5 \times 10^{1}$ & 6,7 & 8,4 & 3,1 \\
\hline
\end{tabular}

* Presença de Salmonella sp.na carne 
Estes microorganismos foram encontrados nas amostras analisadas durante todo o período e em todos os pontos estudados, mas em valores aceitáveis, tratando-se de um alimento que permanece exposto ao ambiente. No geral, as amostras de mexilhões provenientes da praia da Barra Seca apresentaram as maiores contagens para CT e as do costão do Cedro, as menores, excetuando-se as coletas de novembro, quando a média do costão do Cedro atingiu $1,3 \times 10^{3} \mathrm{NMP} / \mathrm{g}$ da amostra.

Para coliformes fecais (CF) as amostras da Barra Seca tiveram o mesmo comportamento. No entanto, em dezembro, as amostras da praia do Engenho superaram suas contagens para CF, atingindo $23 \mathrm{NMP} / \mathrm{g}$ do produto. Segundo o Anexo 1 da Portaria nº 451 do Ministério da Saúde (Brasil, 1998), o limite de tolerância para CF em moluscos in natura, refrigerados ou congelados, é $10^{2} \mathrm{NMP} / \mathrm{g}$. Este limite só foi ultrapassado na coleta de março, pela amostra da Barra Seca (3,2x10² NMP/ g), período em que a água também estava fora dos padrões estipulados pelo CONAMA. Apesar de satisfazer a referida legislação, no mês de fevereiro, os mexilhões provenientes da praia da Barra Seca apresentaram uma população média de CF igual a 9,3×10¹ NMP/ g.

Nos EUA, quando os moluscos são coletados em áreas de cultivo, cuja água excede os níveis de contaminação apontados pela legislação, sua utilização é vetada para consumo humano direto. Na Europa, os indicadores são medidos na carne dos moluscos; tanto nos EUA como na Europa, os padrões baseiam-se na análise bacteriológica do número mais provável (NMP). No Brasil, não existe monitoramento das áreas de produção, portanto, faz-se necessário controle da matéria-prima para garantia da segurança do consumidor, principalmente, quando se trata de alimentos que são ingeridos inteiros, sem a retirada do trato gastrointestinal, como é o caso do mexilhão. $10 \%$ das amostras analisadas não atingiram o limite de detecção da metodologia utilizada (<3NMP/g).

De acordo com a Empresa de Pesquisa Agropecuária e Difusão de Tecnologia de Santa Catarina (EPAGRI), a presença de CF nas zonas costeiras é fato comum no mundo inteiro (EPAGRI, 1994). Estas são consideradas as melhores áreas para a produção de bivalves, mas a concentração destes microorganismos, no tecido comestível dos moluscos, indica o perigo potencial à saúde dos consumidores. A exemplo disto, a 
legislação vigente para alimentos, Resolução - RDC n ${ }^{0} 12$ da ANVISA, não contempla estes microorganismos em pescado in natura.

As bactérias CF não são, por si só, prejudiciais à saúde humana, porém indicam a possibilidade de presença de quaisquer organismos patogênicos. Levando-se em conta que estes microorganismos não vivem em condições de refrigeração, sua presença está associada ao ambiente de origem (água de cultivo) ou a uma manipulação inadequada, ou seja, a condições higiênico-sanitárias insatisfatórias.

Os equipamentos utilizados, principalmente, a mesa de limpeza, normalmente confeccionada em madeira (o que é inadequado, pois seu uso promove formação de fissuras que servem de local para multiplicação de microorganismos, bem como tornam difícil a desinfecção destas), é um ponto crítico de controle da cadeia do mexilhão, que pode ser melhorado. Uma alternativa seria a aquisição de equipamentos de fácil desinfecção como, por exemplo, a mesa de aço inox. Esta, no entanto, é considerada de custo elevado para os produtores. Outra alternativa é a limpeza constante destes equipamentos com escovão, devidamente higienizado, e ainda, a secagem destas mesas de madeira ao sol. Além, logicamente, da desinfecção dos outros equipamentos e utensílios utilizados como barcos, baldes e embalagens, utilizados no transporte.

Quanto aos locais de manipulação, constatou-se a ausência de sombreamento na praia do Engenho; e a radiação solar também atinge a balsa de manipulação do costão do Cedro, fato que, nas condições atuais de manipulação, tornou-se positivo, pois apesar de não ser indicada a exposição do pescado a radiação solar direta, esta pode propiciar uma “desinfecção” dos equipamentos de madeira. Fato que não ocorre na praia da Barra Seca, cujo local de manipulação é sombreado e aparentemente úmido, o que pode ter propiciado as maiores contagens para coliformes encontradas nesta pesquisa.

Pelo fato de serem sensíveis e morrerem dentro de 2 dias em água do mar, os CF não são os melhores indicadores possíveis de contaminação fecal. Os estreptococos sobrevivem durante mais tempo no meio aquático (Gibson, 1999). Então, a presença de CF no mexilhão analisado pode estar associada à contaminação fecal recente dos ambientes de cultivo, ou melhor dizendo, a constante descarga de efluentes nos locais estudados. Os locais destinados a mitilicultura não deveriam receber esgoto, 
principalmente, sem tratamento prévio. Para este tipo de perigo o monitoramento das áreas de cultivo poderia minimizar o risco, caracterizando um Ponto Crítico de Controle (PCC). Apesar do cultivo do costão do Cedro, assim como o da Barra Seca, encontrar-se próximo de áreas densamente povoadas, neste observou-se as menores contagens para CT. Fato que pode estar associado a cloração do efluente previamente à sua descarga no ambiente, bem como a maior distância da costa $(4 \mathrm{Km})$.

\subsubsection{Staphylococcus aureus}

S.aureus foi detectado em todas as amostras de carne de mexilhão, aqui

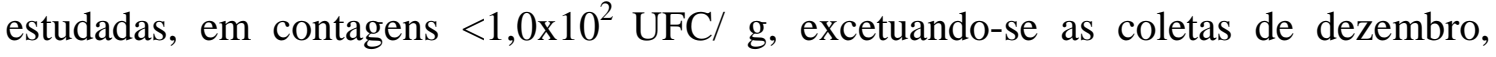

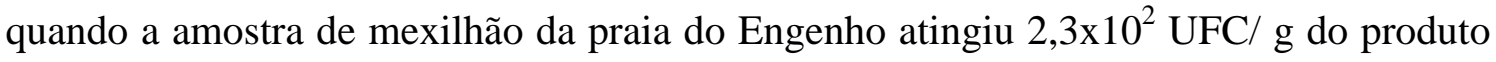
e, de novembro, quando o Costão do Cedro atingiu $1,3 \times 10^{2} \mathrm{UFC} / \mathrm{g}$, como pode ser visualizado na Tabela 7. Esta bactéria é encontrada no corpo humano e transferida ao alimento por pessoas com pobre hábito de higiene, por isso, a presença desta, pode refletir o manuseio e/ou condições de armazenamento inadequadas. 
Tabela 7. Staphylococcus aureus (UFC/g), 24 horas após as coletas

\begin{tabular}{|c|c|c|c|}
\hline Meses & Local & $\begin{array}{l}\text { S. aureus } \\
\text { (água) }\end{array}$ & $\begin{array}{l}\text { S. aureus } \\
\text { (mexilhões) }\end{array}$ \\
\hline \multirow[t]{3}{*}{ Novembro } & Engenho & $<1,0 \times 10^{1}$ & $<1,0 \times 10^{2}$ \\
\hline & Barra Seca & $<1,0 \times 10^{1}$ & $<1,0 \times 10^{2}$ \\
\hline & Costão & $<1,0 \times 10^{1}$ & $1,3 \times 10^{2}$ \\
\hline \multirow[t]{3}{*}{ Dezembro } & Engenho & $<1,0 \times 10^{1}$ & $2,3 \times 10^{2}$ \\
\hline & Barra Seca & $<1,0 \times 10^{1}$ & $<1,0 \times 10^{2}$ \\
\hline & Costão & $<1,0 \times 10^{1}$ & $<1,0 \times 10^{2}$ \\
\hline \multirow[t]{3}{*}{ Janeiro } & Engenho & $<1,0 \times 10^{1}$ & $<1,0 \times 10^{2}$ \\
\hline & Barra Seca & $<1,0 \times 10^{1}$ & $<1,0 \times 10^{2}$ \\
\hline & Costão & $<1,0 \times 10^{1}$ & $<1,0 \times 10^{2}$ \\
\hline \multirow[t]{3}{*}{ Fevereiro } & Engenho & $<1,0 \times 10^{1}$ & $<1,0 \times 10^{2}$ \\
\hline & Barra Seca & $<1,0 \times 10^{1}$ & $<1,0 \times 10^{2}$ \\
\hline & Costão & $<1,0 \times 10^{1}$ & $<1,0 \times 10^{2}$ \\
\hline \multirow[t]{3}{*}{ Março } & Engenho & $<1,0 \times 10^{1}$ & $<1,0 \times 10^{2}$ \\
\hline & Barra Seca & $<1,0 \times 10^{1}$ & $<1,0 \times 10^{2}$ \\
\hline & Costão & $<1,0 \times 10^{1}$ & $<1,0 \times 10^{2}$ \\
\hline
\end{tabular}

* Valores médios das triplicatas

Visto a presença constante de S.aureus na água e que esta age como fonte de contaminação, fez-se constante também a presença destes no mexilhão. Fato que pode acarretar sérios problemas no que diz respeito ao armazenamento, pois estes podem se desenvolver produzindo toxinas. Se este alimento for manipulado em condições higiênicas adequadas e armazenado, rapidamente, em temperaturas baixas, como a de refrigeração, estará apto ao consumo humano, mesmo sob as condições reais do local (levemente cozido), visto que as toxinas são produzidas, somente, em temperaturas 
acima de $15^{\circ} \mathrm{C}$, e que todas as amostras analisadas apresentaram-se dentro do limite proposto pela Resolução - $\operatorname{RDC} \mathrm{n}^{0} 12$, do regulamento técnico sobre padrões microbiológicos em alimentos da ANVISA, de 5x10² UFC/ g de pescado (Brasil, 2001).

Os moluscos, quando consumidos crus, representam alto risco ao consumidor, enquanto, se processados a quente (pasteurizados), representam baixo risco. Problema este que pode ser contornado pelo controle do binômio temperatura e tempo do processo. Apesar de existirem especificações para S.aureus, quando se trata do produto final, não são comuns os incidentes de intoxicação devido a ingestão de pescado (Gibson, 1999).

A população de S.aureus nos mexilhões analisados também respeita a legislação americana que preconiza uma contagem de até $10^{4} \mathrm{NMP} / \mathrm{g}$ de pescado. No entanto, esta legislação internacional também limita a comercialização de pescado com resultado positivo para enterotoxina, o que não foi contemplado no presente estudo (Estados Unidos, 2001). Sabe-se que a enterotoxina só é produzida em contagens elevadas de microrganismos, próxima a $10^{5} \mathrm{UFC} / \mathrm{g}$. Estes dados são relevantes, visto que o consumo de mexilhões, localmente, é ainda incipiente e que o fortalecimento da atividade, com consequente aumento da produção, deve projetar este produto para o mercado externo.

\subsubsection{Salmonella}

Apesar dos resultados negativos para as águas de cultivo, foi constatada presença de Salmonella sp nas amostras de mexilhões coletados, em março, na Barra Seca. A origem é incerta, podendo ser ambiental e/ou por uma contaminação pós-coleta, causada por manipulação ou transporte inadequados. O diagnóstico deste microorganismo coincidiu com a maior contagem de CF na carne de mexilhões, confirmando os comentários anteriores, quanto aos CF serem indicadores da presença de organismos patogênicos.

Em conseqüência dos resultados positivos encontrados para Salmonella, em 6,7\% das amostras da carne de mexilhão, medidas preventivas devem ser tomadas, pois a presença deste microorganismo indica risco aos consumidores, visto a freqüente 
associação deste às doenças gastrointestinais. Para isto, o cozimento adequado do produto para consumo é recomendado, já que a Salmonella apresenta baixa resistência a este processo. Silva Júnior (1995), levando em consideração as condições mais críticas de contaminação, desde a recepção até o consumo do pescado, sugeriu a temperatura de $73^{\circ} \mathrm{C}$, por pelo menos 3 minutos, como ideal para cocção do alimento.

Martinez-Urtaza et al. (2004) isolaram Salmonella Senftenberg de mexilhões provenientes de ambientes altamente salinos e observaram resistência deste microorganismo a condições desfavoráveis, bem como, uma preferência deste por ambientes limpos. Observaram também, que a S. Senftenberg poderia ser isolada dos mexilhões tratados ao vapor, mas que não sobrevivia após imersão destes em água a $80^{\circ} \mathrm{C}$, por $1 \mathrm{~min}$, ou seja, o cozimento com água é mais eficiente.

\subsection{2 Água de cultivo}

\subsubsection{Coliformes totais e fecais}

Neste estudo foram diagnosticadas presença constante de coliformes totais -CT e coliformes fecais -CF nas águas dos três pontos de cultivo estudados. O NMP de CT e $\mathrm{CF} / 100 \mathrm{~mL}$ oscilou entre $<3$ a 4,6×10². As maiores contagens de CF ocorreram em março de 2003, para todos os pontos analisados, como podemos observar pela Tabela 1. No entanto, apenas para a praia da Barra Seca obteve-se contagem média de 57,4 NMP/ mL, superior ao limite estipulado pela legislação vigente. O RIISPOA condena o consumo de pescado proveniente de águas contaminadas ou poluídas (Brasil. 1980). Segundo Hagler \& Hagler (1988), os coliformes têm pouca tolerância à salinidade das águas do mar, portanto, sua detecção nesse ambiente denota uma descarga constante de matéria fecal.

Os resultados encontrados nesta pesquisa, para as águas de cultivo, apresentaram-se satisfatórios, ou seja, condizentes com a legislação em vigor, para águas Classe V, águas salinas para o uso de criação natural e/ou intensiva de espécies destinadas à alimentação humana e que serão ingeridas in natura. No entanto, a presença 
de bactérias CF acima do limite estipulado pela Resolução do CONAMA, em 4,5\% das amostras de água, vem reforçar a necessidade de um programa de monitoramento da qualidade da água em regiões de cultivo, garantindo a segurança do consumidor, principalmente, considerando que o consumidor, em potencial, de mexilhões é o turista e, o maior acesso destes no verão, aumenta os problemas de contaminação devido à elevada carga de efluentes despejados na água nesta época.

Seria conveniente uma amostragem mais abrangente para melhor caracterização das áreas. No entanto, a realização deste trabalho no período do verão favorece a investigação em períodos críticos nestes locais, visto que, nestes meses, a densidade da população de microorganismos é, normalmente, superior aos outros períodos do ano. Ou seja, além da pesquisa ter se realizado no período crítico do ano, também o foi, no de maior demanda do produto. A maior densidade destes microorganismos, nos meses do verão, foi detectada em algumas pesquisas (Rodrigues, 1998; Gelli et al., 1998).

Para valores em NMP de CF superiores a 70/ 100 mL de água, faz-se obrigatória a depuração, enquanto, para valores inferiores é dispensável. Áreas que apresentam contagem acima de 700NMP/ 100mL são vetadas (Brasil, 1988). Levando-se em consideração as recomendações do Serviço de Inspeção de Produtos Animais (SIPA) do Ministério da Agricultura, Pecuária e Abastecimento, afere-se que todas as áreas analisadas encontravam-se livres para o cultivo de moluscos destinados ao consumo direto. Entretanto, o maior número de CF na água de cultivo refletiu em maior número destes microorganismos na carne dos mexilhões e, também, na contaminação destes por Salmonella sp.

\subsubsection{Staphylococcus aureus}

A população de S.aureus nas águas de cultivo apresentou-se sempre <10 UFC/ $\mathrm{mL}$, para todos os pontos de coleta e durante todo o período experimental. Apesar de não haver legislação, no quesito água, para este microorganismo, ele foi investigado por apresentar alta tolerância ao sal, bem como, para apurar quanto a origem deste microorganismo no alimento. 
Pode-se afirmar que a contagem encontrada é baixa, principalmente, se considerarmos o limite estipulado pelo Ministério da Saúde para consumo de pescado cru que é inferior a $10^{3} \mathrm{UFC/}$ g de pescado (Brasil. 2001). Visto a presença constante de S.aureus na água e que esta age como fonte de contaminação, fez-se constante também a presença destes no mexilhão. Tendo em vista que os resultados obtidos para este microorganismo, na carne de mexilhões, mostraram-se, praticamente, constantes, podese concluir que a principal fonte de contaminação foi a água de cultivo.

\subsubsection{Salmonella}

Para a água de cultivo, obtiveram-se apenas resultados negativos para Salmonella durante todo o período de estudo para todos os pontos analisados, mesmo nos períodos com elevada carga de coliformes fecais. Martins et al. (1988) encontraram uma relação, praticamente linear, entre os índices de coliformes e as chances de isolamento de Salmonella; no entanto, observaram que haviam situações onde, a Salmonella não era detectada quando os índices de coliformes eram elevados e, outras vezes, frente a níveis baixos de coliformes, estava presente. Estas observações fazem-se compreensíveis, visto a gama de fatores intrínsecos à presença ou ausência de um microorganismo.

No presente estudo pode-se observar que a maior população de CF na água de cultivo refletiu numa maior população destes na carne dos moluscos, bem como, a presença de Salmonella neste lote de mexilhões que apresentaram maior população de CF. Segundo Germano et al. (1993), os resultados negativos para este microorganismo podem estar associados a sua estreita sobrevida em água do mar, ou ainda, a metodologia empregada para esta análise, que utilizou apenas uma alíquota de $25 \mathrm{~mL}$ de água, diminuindo muito a probabilidade de detecção (Huss et al., 2000; World Health Organization- WHO, 1999).

A veiculação hídrica deste microorganismo é restrita a pequenos relatos e a falta de saneamento, visto que, a presença destas bactérias na água depende do número de indivíduos infectados na população. No entanto, há casos associados ao consumo de organismos aquáticos (mariscos) e vegetais crus (Pádua, 2003). 


\subsection{Conclusões}

- A qualidade microbiológica satisfatória da água de cultivo propiciou a produção de mexilhões de qualidade aceitáveis, viabilizando a produção destes organismos na região de estudo.

- Tendo em vista, que os mexilhões coletados mais próximos a saída de efluentes não tratados apresentaram maiores contagens. Os long lines devem ser colocados em locais distantes a saída destes, visando minimizar o risco de contaminação.

- A maior contagem de S. aureus dos mexilhões coletados, em dezembro, no cultivo do Engenho da Almada sugere que estes sofreram uma manipulação menos cuidadosa.

- O risco de toxinfecção causada por S. aureus existe, mas o seu desenvolvimento dependerá da manipulação do produto e sua posterior armazenagem e processamento.

- O lote proveniente da Barra Seca, em março, foi considerado potencialmente capaz de causar uma enfermidade transmitida por alimento -ETA.

\subsection{Recomendações}

- Pelos resultados encontrados neste trabalho pode-se aferir que a aquisição de mexilhões, bem como de outros bivalves, deve sempre levar em conta o local de origem dos mesmos. Um certificado de origem é fundamental, ainda mais se há concorrência irregular do produto cultivado, regionalmente, com os produtos provenientes do extrativismo. 
- Sendo, a enterotoxina produzida pelo $S$. aureus, termoresistente, o melhor seria tratarmos da prevenção do que da destruição do mesmo através de processos.

- O tratamento térmico adequado (pasteurização), previamente ao consumo, pode minimizar o risco de enfermidade, visto que, o patógeno diagnosticado nesta pesquisa (Salmonella sp.) não resiste a este processo.

- Um enfoque maior deve ser dado na legislação brasileira quanto a microbiota das águas de cultivo, visto que a alta perecibilidade do pescado, de forma geral, e o tempo exigido para incubação limitam o uso das contagens microbianas da carne como índice de qualidade.

\subsection{Referências bibliográficas}

AMERICAN PUBLIC HEALTH ASSOCIATION (APHA). Standard methods for the examination of water and wastewater. 20.ed. Washington, 1998. 937p.

ANDREWS, W.H.; FLOWERS, R.S.; SILLIKER, J.; BAILEY, J.S. Salmonella. In: VANDERZANT, C. (Ed.). Compendium of methods for the microbiological examination of foods. 4.ed. Washington: American Public Health Association, 1992. cap.25, p.371-415.

BENNETT, A.R.; MACPHEE, S.; BETTS, R.; POST, D. Use of pyrrolidonyl peptidase to distinguish Citrobacter from Salmonella. Letters in Applied Microbiology, v.28, p.175-178, 1999. 
BRASIL. Ministério da Agricultura, Pecuária e Abastecimento. Regulamento da Inspeção Industrial e Sanitária de Produtos de Origem Animal - RIISPOA. Brasília, 1980. 165p.

BRASIL. Ministério da Agricultura, Pecuária e Abastecimento. Serviço de Inspeção de Produtos Animais (SIPA). Informações Dipes n⿳0 097/88. Brasília, 1988. p.32-35.

BRASIL. Ministério do Meio Ambiente. Conselho Nacional do Meio Ambiente CONAMA. Resoluções: Resolução n.20 de 18 de junho de 1986. http://www.mma.gov.br/port/conama/res/res86/res2086.html (27 ago. 2001)

BRASIL. Ministério da Saúde. Agência Nacional da Vigilância Sanitária (ANVISA). Legislação: Resolução - RDC n.12, de 02 de janeiro de 2001. http://www.anvisa.gov/legis/resol./1201redc.htm (27 ago. 2001)

BRASIL. Ministério da Saúde. Secretaria da Vigilância Sanitária. Portaria no 451, de 19 de setembro de 1997: princípios gerais para o estabelecimento de critérios e padrões microbiológicos aplicáveis aos alimentos. Brasília, 1998. 37p.

COMPANHIA DE TECNOLOGIA DE SANEAMENTO AMBIENTAL (CETESB). Guia de coleta e preservação de amostras de água. São Paulo, 1988. 149p.

COMPANHIA DE TECNOLOGIA DE SANEAMENTO AMBIENTAL (CETESB). Relatório de balneabilidade das praias paulistas 2001. São Paulo, 2002. 209p. (Série Relatórios / Secretaria de Estado do Meio Ambiente)

COOK, D.W. Microbiology of bivalves molluscan shellfish. In: WARD, D.R. HACKNEY, C. Microbiology of marine food products. New York: Van Nostrand Reinhold, 1991. cap.2, p.19-34. 
EMPRESA DE PESQUISA AGROPECUÁRIA E DIFUSÃO DE TECNOLOGIA DE SANTA CATARINA (EPAGRI). Manual do cultivo do mexilhão Perna perna. Florianópolis, 1994. 140 p.

ESTADOS UNIDOS. National Advisory Committee on Microbial Criteria for Foods (NACMCF). Hazard analysis critical control point system. International Journal of Food Microbiology, v.16, p.1-23, 1992.

ESTADOS UNIDOS. Food \& Drug Administration. Center of Food Safety \& Applied Nutrition. Fish and fisheries products hazards and controls guidance. 3.ed. Rome, 2001. http://www.cfsan.fda.gov/ comm/haccp4x5.html (28 Nov. 2003)

GELLI, V.C.; CARNEIRO, M.H. Subsídios para elaboração do plano de ação e gestão para o desenvolvimento sustentável do litoral norte de São Paulo. São Paulo: Secretaria de Meio Ambiente do Estado de São Paulo, 2002. p.88-90: Quadro evolutivo da pesca e da aqüicultura no litoral norte.

GELLI, V.C.; PEREIRA, R.T.L.; GIFFONI, B.B. et al. Caracterização da mitilicultura no litoral norte de São Paulo. In: SEMANA NACIONAL DE OCEANOGRAFIA, 11., Porto Alegre, 1998. Resumos. Porto Alegre: Ed. Universitária, 1998. p.37-40.

GERMANO, P.M.L.; OLIVEIRA, J.C.F.; GERMANO, M.I.S. O pescado como causa de toxinfecções bacterianas. Higiene Alimentar, v.7, n.28, p.40-45, 1993.

GIBSON, D.M. Higiene y seguridad del pescado y del marisco. In: RUITER, A. (Ed.). El pescado y los productos derivados de la pesca: composición, propriedades nutritivas y estabilidad. Acribia: Zaragoza, 1999. cap.8, p.257-303. 
HAGLER, A.N.; HAGLER, L.C.S.M. Indicadores microbiológicos de qualidade sanitária. In: ROITMAM, I.; TRAVASSOS, L.R.; AZEVEDO, J.L. Tratado de microbiologia. São Paulo: Manole, 1988. v.1, cap.3, p.88-96.

HITCHINS, A.D.; FENG, P.; WATKINS, W.D.; RIPPEY, S.R.; CHANDLER, L.A. Escherichia coli and the Coliform bacteria. http://www.cfsan.fda.gov (14 Oct. 2001)

HUSS, H.H. Development and use of the HACCP concept in fish processing. International Journal of Food Microbiology, v.15, p.33-44, 1992.

HUSS, H.H.; REILLY, A.; EMBAREK, P.K.B. Prevention and control of hazards in seafood. Food Control, v.11, p.149-156, 2000.

LANCETTE, G.A.; TATINI, S.R. Staphylococcus aureus . In: DOWES, F.P.; ITO, K. (Ed.). Compendium of methods for the microbiological examination of foods. 4.ed. Washington: American Public Health Association, 2001. p.387-403.

LIRA, A. de A.; BARROS, G.C. de.; LIMA, M.C.G. de.; MOTA, R.A. Aspectos sanitários do ambiente aquáticos onde são capturados moluscos bivalves para consumo no Grande Recife, PE. Higiene Alimentar, v.11, n.77, p.53-57, out 2000.

MARQUES, H.L.A.; PEREIRA, R.L. Levantamento e dimensionamento preliminares das áreas mais favoráveis para a prática da mitilicultura no Litoral do município de Ubatuba, Estado de São Paulo (23 $25^{0}$ ' S, $045^{0} 04^{\prime}$ ' W). São Paulo: Instituto de Pesca, 1989. 10p. (Boletim Técnico do Instituto de Pesca, 13) 
MARTINEZ-URTAZA, J.; PEITEADO, J.; LOZANO-LEON, A.; GARCIA-MATIN, O. Deteccion of Salmonella Senftenberg associated with high saline environments in mussel processing facilities. Journal of Food Protection, v.67, n.2, p.256-263, Feb. 2004.

MARTINS, M.T.; PESSOA, G.V.A.; SANCHEZ, P.S. et al. Isolamento de Salmonella no ambiente aquático: significado sanitário. Revista de Microbiologia, v.19, n.1, p.29-39, 1988.

PÁDUA, H.B. de. Informações sobre os coliformes totais/ fecais e alguns outros organismos indicadores em sistemas aquáticos: aqüicultura. http:// www.setorpesqueiro.com.br (12 ago. 2003)

RODRIGUES, P.F. Caracterização sanitária de áreas de criação de moluscos bivalvos do litoral norte do estado de São Paulo. São Paulo, 1998. 66p. Dissertação (Mestrado) - Instituto de Biociências, Universidade de São Paulo.

SILVA JÚNIOR, E.A Manual de controle higiênico-sanitário em alimentos. São Paulo: Livraria Varela, 1995. 347p.

WORLD HEALTH ORGANIZATION (WHO). Food safety issue associated with products from aquaculture. Roma: FAO, 1999. (Report of a Joint FAO/NACA/FAO Study Group WHO Technical Report Series, 883) 


\section{CONCLUSÕES GERAIS}

Os resultados obtidos neste estudo para o mexilhão Perna perna cultivado na região de Ubatuba, São Paulo - Brasil, permitem estabelecer as seguintes conclusões:

- Há variação dos constituintes químicos dos mexilhões em função da sazonalidade, bem como, do local de origem destes.

- O mexilhão é uma fonte protéica com baixo teor lipídico e calórico.

- Os mexilhões comercializados em Ubatuba apresentam bom rendimento, considerando o Índice de Condição Comercial proposto por Gomes et al. (1998).

- Seguindo os padrões do RIISPOA para pescado, quanto a BNVT e pH, os mexilhões apresentaram uma vida útil de 5 dias sob a temperatura de $10^{\circ} \mathrm{C}( \pm 1)$.

- Os mexilhões comercializados em Ubatuba, SP., até 24 horas após coleta, apresentaram-se com qualidade satisfatória para consumo quanto aos quesitos físico-químicos aqui analisados. Excetuando-se, no mês de fevereiro, quando os valores de TMA encontrados superaram a legislação vigente.

- A qualidade microbiológica satisfatória da água de cultivo propiciou a produção de mexilhões de qualidade aceitáveis, viabilizando a produção destes organismos na região de estudo. 
- Tendo em vista, que os mexilhões coletados mais próximos a saída de efluentes não tratados apresentaram maiores contagens, os long lines devem ser colocados em locais distantes a saída destes, visando minimizar o risco de contaminação.

- A maior contagem de S. aureus dos mexilhões coletados, em dezembro, no cultivo do Engenho da Almada sugere que estes sofreram uma manipulação menos cuidadosa.

- O risco de toxinfecção causada por S. aureus existe, mas o seu desenvolvimento dependerá da manipulação do produto e sua posterior armazenagem e processamento.

- O lote proveniente da Barra Seca, em março, foi considerado potencialmente capaz de causar uma enfermidade transmitida por alimento -ETA. 


\section{REFERÊNCIAS BIBLIOGRÁFICAS}

AMANAJÁS, C.C. Determinação dos compostos básicos totais de pescado e seu potencial para avaliação do frescor. Campinas, 1985. 78p. Dissertação (Mestrado) Faculdade de Engenharia de Alimentos e Agrícola, Universidade Estadual de Campinas.

ANDREU, B. El cultivo del mejillon en Europa. I. Métodos y tecnicas utilizadas. Anais da Academia Brasileira de Ciências, v.47, p.11-21, 1976a. Suplemento.

ANTANOCOPOULOS, N.; VINCKE, W. Determination of volatile basic nitrogen in fish: a third colaborative study by the West European Fish Technologists Association (WEFTA). Zeitschrift Lebensm Unters Forsch, v.189, p.309, 1989.

ANTONIOLLI, M.A. Vida útil do mexilhão Perna perna L. processado e mantido sob refrigeração. Florianópolis, 1999. 99p. Dissertação (Mestrado) - Universidade Federal de Santa Catarina.

ARANA, L.V. Aqüicultura e desenvolvimento sustentável. Florianópolis: UFSC, 1999. 310p.

ARANA, L.V. Gestão da aqüicultura em ambientes multi-usuários: estudo de caso da maricultura na baía de Florianópolis, Santa Catarina: litoral: beleza e transformação. http://www.conciencia.br/reportagens/litoral/lit14.shtml (19 abril 2003) 
ASSUMPÇÃO, A. Estudo da viabilidade de criação de cooperativa dos produtores de mexilhões do litoral norte paulista. Piracicaba: ESALQ. Depto. Economia, Administração e Sociologia, 1999. 30p. (Relatório CES, 629)

BARNI, E.J.; SILVA, M.C.; ROSA, S.C.C. et al. Estudo do mercado de mexilhões em São Paulo, Curitiba e Porto Alegre. Florianópolis: Empresa de Pesquisa Agropecuária e Extensão Rural de Santa Catarina (EPAGRI), 2003. 43p.

BEIRÃO, H.; TEIXEIRA, E.; MEINERT, E.M. et al. Processamento e industrialização de moluscos. In: SEMINÁRIO E WORKSHOP TECNOLOGIA PARA APROVEITAMENTO INTEGRAL DO PESCADO, Campinas, 2000. Campinas: ITAL, Centro de Tecnologia de Carnes, 2000. p.38-84.

BORGHETTI, J.R.; OSTRENSKY, A. A cadeia produtiva da aqüicultura brasileira. In: VALENTI, W.C.; POLLI, C.R.; PEREIRA, J.A.; BORGUETI, J.R. Aqüicultura no Brasil. Brasília: CNPq, 2000. p.107-142.

BOTTA, J.R. Freshness quality of seafoods: a review. In: SHAHIDI, F.; BOTTA, J.R. (Ed.). Seafoods. London: Chapman \& Hall, 1994. cap.9, p.140-167.

BRASIL. Ministério da Agricultura, Pecuária e Abastecimento. Regulamento da Inspeção Industrial e Sanitária de Produtos de Origem Animal - RIISPOA. Brasília, 1980. 165p.

BRASIL. Ministério da Agricultura e Abastecimento. Secretaria Executiva. Departamento de Pesca e Aqüicultura (DPA). http://200.252.165.21/dpa/molusco09.htm (13 mar. 2002)

BRASIL. Ministério da Agricultura, Pecuária e Abastecimento. Serviço de Inspeção de Produtos Animais (SIPA). Informações Dipes no 097/88. Brasília, 1988. p.32-35. 
BRASIL. Ministério do Meio Ambiente. Conselho Nacional do Meio Ambiente (CONAMA). Resoluções: Resolução n.20, de 18 de junho de 1986. http://www.mma.gov.br/port/conama/res/res86/res2086.html (27 ago. 2001)

BRASIL. Ministério da Saúde. Agência Nacional da Vigilância Sanitária (ANVISA). Legislação: Resolução - RDC n.12, de 02 de janeiro de 2001. http://www.anvisa.gov/legis/resol./1201redc.htm (27 ago. 2001)

CANADÁ. Shellfish Water Quality Protection Program. Shellfish and water quality: environment Canada. http://Quality\Shellfish\%20and\%20Water\%20Quality.htm (13 Apr. 2004)

CARDOSO, E.S. Pescadores artesanais: natureza, território, movimento social. São Paulo, 2001. 143p. Tese (Doutorado) - Faculdade de Filosofia, Letras e Ciências Humanas, Universidade de São Paulo.

COMPANHIA DE TECNOLOGIA E SANEAMENTO AMBIENTAL (CETESB). Relatório de balneabilidade das praias paulistas 2001. São Paulo, 2002. 209p.

CONTRERAS GUZMÁN, E.S. Bioquímica de pescados e derivados. Jaboticabal: FUNEP, 1994. 409p.

DAVIS, H.K. Calidad y alteración del pescado crudo. In: RUITER, A. El pescado y los productos derivados de la pesca: composición, propiedades nutritivas y estabilidad. Zaragoza: Acribia, 1999. cap.7, p.225-256.

DORÉ, I. Fish and shellfish quality assessment: a guide for retailers and restauranteurs. New York: Van Nostrand Reinhold, 1941. p.44. 
EHIRA, S.; UCHIYAMA, H. Determination of fish freshness using the $k$ value and comments on some other biochemical changes in relation to freshness. In: KRAMER, D.E.; LISTON, J. (Ed.). Seafood quality determination. New York: Elsevier, 1987. p.185-207.

EIROA, M.N.U. Aspectos microbiológicos relacionados à conservação e ao consumo de pescado. Boletim da Sociedade Brasileira de Ciência e Tecnologia de Alimentos, n.54, p.9-37, 1980.

ESPÍNOLA, O.; DIAS, R.R.C. O mexilhão como matéria-prima alimentar. ABIA/SAPRO, n.47, p.10-30, abr. 1980.

ESTADOS UNIDOS. National Advisory Committee on Microbial Criteria for Foods (NACMCF). Hazard analysis critical control point system. International Journal of Food Microbiology, v.16, p.1-23, 1992.

ESTADOS UNIDOS. Food \& Drug Administration. Center of Food Safety \& Applied Nutrition. National shellfish sanitation program model ordinance. 1999. cap.4. http://vm.cfsan.fda.gov/ ear/nsspor04.html (12 mar. 2004)

EU COMMISSION. Freshness, quality and safety in seafoods. http://www.seafood.ucdavis.edu/pubs/qualitysafety.doc (16 Jan. 2004)

FAO. El estado de los recursos pesqueros: tendencias de la producción, aprovechamiento y comercio. http://www.fao.org/DOCREP/003/X8002S/x8002s04. htm (4 Jul. 2001) 
FAO. El estado mundial de la pesca y la acuicultura: examen mundial de la pesca y la acuicultura. Parte 1. El estado de los recursos pesqueros: tendencias de la producion, aproveitamento y comercio. http://www.fao.org/docrep/005/y7300s/ y7300s04.htm (20 Apr. 2003a)

FAO. Fisheries Department Statistical Databases and Software 2001: capture production respect to the previous year. http://www.fao.org/fi/statist/snapshot/ 01vs00/01vs00.asp (20 Apr. 2003b)

FAO. Fishery country profile. http://www.fao.org/fi/fcp/es/BRA/profile.htm Mar. 2004)

FAO. The state of world fisheries and aquaculture 2002: (SOFIA). Parte 4. Outlook. http://www.fao.org/docrep/005/y7300e08.html (16 Dec. 2003c)

FAO. Fisheries Department Statistical Databases and Software: capture production respect to the previous year. http://www.fao.org (20 Dec. 1999)

FREITAS, J.C. O potencial farmacológico das toxinas marinhas (reportagem): litoral transformação e beleza. http://www.comciencia.br/reportagens/litoral/ lit20.shtml (08 maio 2003)

GELLI, V.C.; CARNEIRO, M.H. Situação atual da pesca e da maricultura no litoral Norte de São Paulo. São Paulo: Secretaria da Agricultura e Abastecimento, APTA, Instituto de Pesca, Núcleo de Pesquisa e Desenvolvimento do Litoral Norte, 2003. 30p. 
GELLI, V.C.; MACHADO, I.C.; PEREIRA, O.M. Diagnóstico da criação de moluscos bivalves no litoral paulista (compact disc). In: SIMPÓSIO BRASILEIRO DE OCEANOGRAFIA, 1., São Paulo, 2002. Anais. São Paulo: USP, Instituto Oceanográfico, 2002.

GELLI, V.C.; PEREIRA, R.T.L.; GIFFONI, B.B. et al. Caracterização da mitilicultura no litoral norte de São Paulo. In: SEMANA NACIONAL DE OCEANOGRAFIA, 11., Porto Alegre, 1998. Resumos. Porto Alegre: Ed. Universitária, 1998. p.37-40.

GOMES, R.O.; MARENZI, A.W.C.; MANZONI, G.C. Utilização econômica do índice de condição do mexilhão Perna perna (L., 1758), no parque de mitilicultura na enseada de Armação do Itapocoroy, (2647’S-48³6’W) Penha, SC, Brasil. In: SIMPÓSIO BRASILEIRO DE AQUICULTURA, 10., Recife, 1998. Resumos. Recife: Universidade Federal de Pernambuco, 1998. p.119.

HEBARD, C.E.; FICK, G.J.; MARTIN, R.E.. Occurrence and significance of trimethylamine oxide and its derivatives in fish and shellfish. In: MARTIN, R.E.; FLICK, G.J.; HEBERD, C.E.; WARD, D.R. (Ed.). Chemistry \& biochemistry of marine food products. Westport: The Avi Publishing Company, 1982. p.149-304.

HENRIQUES, M.B. Avaliação dos bancos naturais do mexilhão Perna perna (Linnaeus, 1758) na baía de Santos, estado de São Paulo. Rio Claro, 2001. 74p. Dissertação (Mestrado) - Centro de Estudos Ambientais, Universidade Paulista “Júlio Mesquita Filho”.

HILTZ, D.F.; DYER, W.J.; NOWLAN, S. et al. Variation of biochemical quality indices by biological and technological factors. In: KREUZER, R. Fish inspection and quality control. London: Fishing News Book, 1971. p.191-195. 
HUSS, H.H. Assurance of seafood quality. Rome: FAO, 1993. 169p. (FAO Fisheries technical paper, 334)

JACOB, F.G.B.; Diagnóstico ambiental em Ubatuba, SP (compact disc). In: SIMPÓSIO BRASILEIRO DE OCEANOGRAFIA, 1., São Paulo, 2002. Anais. São Paulo: USP, Instituto Oceanográfico, 2002.

JOSÉ, V.P. Bivalves e a segurança do consumidor. São Paulo, $1996.182 p$. Dissertação (Mestrado) - Faculdade de Saúde Pública, Universidade de São Paulo.

JOSUPEIT, H.; LEM, A.; LUPIN,H. Aquaculture products: quality, safety: marketing and trade. In: SUBASINGHE, R.P.; BUENO, P.B. et al. (Ed.). Aquaculture in the third millennium. Rome: FAO, 2001. p.249-257.

LAMPARELLI, C.C. O bivalve Perna perna (Linnaeus, 1758) como amostrador biológico das condições ecológico-sanitárias de águas costeiras. São Paulo, 1987. 124p. Dissertação (Mestrado) - Instituto de Ciências Biológicas, Universidade de São Paulo.

LISTON, J. Microbiology in fishery science. In: CONELL, J.J. (Ed.). Advances in fishery science and technology. London: Fishing News Book, 1980. p.138-157.

LUNETTA, J.E. Fisiologia da reprodução de mexilhões (Mytilus perna L. Mollusca Lamellibranchia). Boletim de Zoologia e Biologia Marinha, n.26, p.33-111, 1969.

MAGAlHÃES, A.R.M. Teor de proteínas do mexilhão Perna perna (Linné, 1758) (MOLLUSCA, BIVALVIA), em função do ciclo sexual. São Paulo, 1985. 117p. Dissertação (Mestrado) - Instituto de Biociências, Universidade de São Paulo.

MARQUES, H.L.A. Criação comercial de mexilhões. São Paulo: Nobel, 1998. 109p. 
MARQUES, H.L.A; PEREIRA, R.L. Levantamento e dimensionamento preliminares das áreas mais favoráveis para a prática da mitilicultura no litoral do município de Ubatuba, estado de São Paulo $\left(23^{0} 25^{\prime} \mathrm{S}, 045^{0} 04^{\prime} \mathrm{W}\right)$. São Paulo, 1989. 10p. (Boletim Técnico do Instituto de Pesca, 13)

MEDEIROS, K.J.; BEIRÃO, L.H.; TRAMONTE, V.L.C.G. et al. Composição de ácidos graxos e colesterol em mexilhões Perna perna. In: CONGRESSO NACIONAL DA SOCIEDADE BRASILEIRA DE ALIMENTAÇÃO E NUTRIÇÃO, 6., Florianópolis, 2001. Resumos. Florianópolis: SBAN, 2001. p.319.

MOLUSCOS: cadeia produtiva: histórico do cultivo de moluscos bivalves no Brasil. http://www.setorpesqueiro.com.br (12 mar. 2002)

OGAWA, M.; MAIA, E.L. Manual da pesca. São Paulo: Varela, 1999. 430p.

OSTRENSKY, A.; BORGHETTI, J.R.; PEDINI, M. Situação atual da aqüicultura brasileira e mundial. In: VALENTI, W.C.; POLI, C.R.; PEREIRA, J.A.; BORGETTI, J.R. Aqüicultura no Brasil. Brasília: Cnpq, 2000. p.355-381.

PÁDUA, H.B. de. Informações sobre os coliformes totais / fecais e alguns outros organismos indicadores em sistemas aquáticos: aqüicultura, 2003. 20p. http:// www.setorpesqueiro.com.br (12 ago. 2003)

PEREIRA, O.M.; GELLI, V.C.; HENRIQUES, M.B. et al. Programa de desenvolvimento da criação ordenada de moluscos bivalves no Estado de São Paulo. http://www.pesca.sp.gov.br/RelTec2.htm (10 out. 2002)

PREGNOLATTO, W.; PREGNOLATTO, N.P. Normas analíticas do Instituto Adolfo Lutz. São Paulo: Instituto Adolfo Lutz, 1985. v.1. 
PROENÇA, C.E.M.; AVELAR, J.C.; NETO, F.M.O. Plataforma do agronegócio da malacocultura. Brasília: Cnpq / MAPA, DPA, 2001. 76p.

QUAYLE, D.B.; NEWKIRK, G.F. Farming bivalve molluscs: methods for study and development. In: SANDIFER, P.A. Advances in world aquaculture. Toronto: The World Aquaculture Society, 1989. v.1.

RIBEIRO, K. Fim do mangue derruba pesca e renda. Folha Vale. Ambiente, São Paulo, 17 mar. 2002. p.C1.

RINALDI, F.D.; FURLAN, E.F.; GALVÃO, J.A. et al. Produção, comercialização e perspectiva de expansão da atividade de cultivo de mexilhão Perna perna (L.) na região de Ubatuba, SP (compact disc). In: SIMPÓSIO INTERNACIONAL DE INICIAÇÃO CIENTÍFICA DA UNIVERSIDADE DE SÃO PAULO, 11. Piracicaba, 2003. Resumos. São Paulo: USP, 2003.

RODRIGUES, P.F. Caracterização sanitária de áreas de criação de moluscos bivalvos do litoral norte do Estado de São Paulo. São Paulo, 1998. 66p. Dissertação (Mestrado) - Instituto de Biociências, Universidade de São Paulo.

RODRÍGUEZ-JÉREZ, J.J; HERNÁNDEZ-HERRERO, M.M.; ROIG-SAGUÉS, A.X. New methods to determine fish freshness in research and industry. http://ressources.cibeam.org/om/pdf/c51/00600292.pdf (15 Mar. 2004)

ROSA, R.C.C.; GUZENSKI, J.; PEREIRA. A. et al. Manual de cultivo do mexilhão Perna perna. Florianópolis: EPAGRI, 1994. 140p. 
SERVIÇO DE APOIO ÀS MICRO E PEQUENAS EMPRESAS DE SÃO PAULO (SEBRAE); UNIVERSIDADE FEDERAL DE SÃO CARLOS. Grupo de estudos e pesquisas agroindustriais. Diagnóstico e proposição de ações de melhoria da eficiência e da competitividade das cadeias produtivas da carcinicultura marinha e moluscos bivalves no Estado de São Paulo (compact disc). São Carlos, 2002.

SIKORSKI, Z.E.; SUN PAN, B. Preservation of seafood quality. In: SHAHIDI, F.; BOTTA, J.R. (Ed.). Seafood. London: Chapman \& Hall, 1994. cap.10, p.168-195.

SIKORSKI, Z.E.; KOLAKOWSKA, A.; BURT, J.R. Cambios bioquímicos y microbianos subsiguientes a la captura. In: SIKORSK, Z.E. (Ed.). Tecnologia de los productos del mar: recursos, composicion nutritiva y conservacion. Zaragoza: Acribia, 1994. cap.4, p.75-91.

SILVA, L.I.L.; SILVA, J.D. de O. Lula assina decreto das águas públicas. Panorama da Aqüicultura, v.13, n.80, p.60-65 nov./dez. 2003.

SOUZA, R.C.C.L. de. Bivalves marinhos introduzidos no Brasil. In: ENCONTRO BRASILEIRO DE MALACOLOGIA, 18., Rio de Janeiro, 2003. Resumos. Rio de Janeiro: UERJ, 2003.

SPINELLI, M.R.; EKLUND, M.; MIYAUCHI, D. Mensurement of hypoxanthine in fish as a method of assessing freshness. Journal of Food Science, v.19, p.710-714, 1964. 
WESTLUND, L. Apparent historical consumption and future demand for fish and fishery products: exploratory calculations. In: KIOTO CONFERENCE OUTCOME \& PAPER PRESENTED. Kioto, 2002. Papers presented. Rome: FAO Fisheries Department, 2003. http://www.fao.org/DOCREP/006/AC442e/AC442e13.htm (17 Dec. 2003)

WOOD, P.C. Manual de hygiene de los mariscos. Zaragoza: Editorial Acribia, 1979. 83p.

YOKOYAMA, V.A.; GALVÃO, J.A.; SALAN, E.O. et al. A importância do cultivo de mexilhão (Perna perna) para as comunidades de pescadores no município de Ubatuba, SP (compact disc). In: SIMPÓSIO INTERNACIONAL DE INICIAÇÃO CIENTÍFICA DA UNIVERSIDADE DE SÃO PAULO, 11., Piracicaba, 2003. Resumos. São Paulo: USP, 2003. 